Effects of Surface Coal Mining and Reclamation on the Geohydrology of Six Small Watersheds in West-Central Indiana

United States Geological Survey Water-Supply Paper 2368-B 


\section{AVAILABILITY OF BOOKS AND MAPS OF THE U.S. GEOLOGICAL SURVEY}

Instructions on ordering publications of the U.S. Geological Survey, along with prices of the last offerings, are given in th current-year issues of the monthly catalog "New Publications of the U.S. Geological Survey." Prices of available U.S. Geologic Survey publications released prior to the current year are listed in the most recent annual "Price and Availability List." Publication that are listed in various U.S. Geological Survey catalogs (see back inside cover) but not listed in the most recent annual "Prir and Availability List" are no longer available.

Prices of reports released to the open files are given in the listing "U.S. Geological Survey Open-File Reports," update monthly, which is for sale in microfiche from the U.S. Geological Survey, Books and Open-File Reports Section, Federal Cente Box 25425, Denver, CO 80225 . Reports released through the NTIS may be obtained by writing to the National Technic Information Service, U.S. Department of Commerce, Springfield, VA 22161; please include NTIS report number with inquiry

Order U.S. Geological Survey publications by mail or over the counter from the offices given below.

\section{BY MAIL}

\section{Books}

Professional Papers, Bulletins, Water-Supply Papers, Techniques of Water-Resources Investigations, Circulars, publications of general interest (such as leaflets, pamphlets, booklets), single copies of Earthquakes \& Volcanoes, Preliminary Determination of Epicenters, and some miscellaneous reports, including some of the foregoing series that have gone out of print at the Superintendent of Documents, are obtainable by mail from

\section{U.S. Geological Survey, Books and Open-File Reports Federal Center, Box 25425 \\ Denver, CO 80225}

Subscriptions to periodicals (Earthquakes \& Volcanoes and Preliminary Determination of Epicenters) can be obtained ONLY from the

\section{Superintendent of Documents Government Printing Office Washington, D.C. 20402}

(Check or money order must be payable to Superintendent of Documents.)

\section{Maps}

For maps, address mail orders to

\section{U.S. Geological Survey, Map Distribution Federal Center, Box 25286 Denver, $\mathrm{CO} 80225$}

Residents of Alaska may order maps from

\author{
Alaska Distribution Section, U.S. Geological Survey \\ New Federal Building - Box 12 \\ 101 Twelfth Ave., Fairbanks, AK 99701
}

\section{OVER THE COUNTER}

\section{Books}

Books of the U.S. Geological Survey are available over th counter at the following U.S. Geological Survey Public Inquirio Offices, all of which are authorized agents of the Superintendent Documents:

- WASHINGTON, D.C.-Main Interior Bldg., 2600 corrido 18th and C Sts., NW.

- DENVER, Colorado-Federal Bldg., Rm. 169, 1961 Stout St.

- LOS ANGELES, California-Federal Bldg., Rm. 7638,300 N Los Angeles St.

- MENLO PARK, California-Bldg. 3 (Stop 533), Rm. 3128, 34 Middlefield Rd.

- RESTON, Virginia-503 National Center, Rm. 1C402, 1220 Sunrise Valley Dr.

- SALT LAKE CITY, Utah-Federal Bldg., Rm. 8105, 125 Sout State St.

- SAN FRANCISCO, California-Customhouse, Rm. 504, 55 Battery St.

- SPOKANE, Washington-U.S. Courthouse, Rm. 678, West 92 Riverside Ave.

- ANCHORAGE, Alaska-Rm. 101, 4230 UniversityDr.

- ANCHORAGE, Alaska-Federal Bldg, Rm. E-146, $701 \mathrm{C} \mathrm{St}$

\section{Maps}

Maps may be purchased over the counter at the U.S. Geologic: Survey offices where books are sold (all addresses in above list) and the following U.S. Geological Survey offices:

- ROLLA, Missouri-1400 Independence Rd.

- DENVER, Colorado-Map Distribution, Bldg. 810, Feder Center

- FAIRBANKS, Alaska-New Federal Bldg., 101 Twelfth Ave. 
Chapter B

Effects of Surface Coal Mining and Reclamation on the Geohydrology of Six Small Watersheds in West-Central Indiana

By JEFFREY D. MARTIN, RICHARD F. DUWELIUS, and CHARLES G. CRAWFORD 


\section{U.S. DEPARTMENT OF THE INTERIOR \\ MANUEL LUJAN, Jr., Secretary}

U.S. GEOLOGICAL SURVEY

Dallas L. Peck, Director

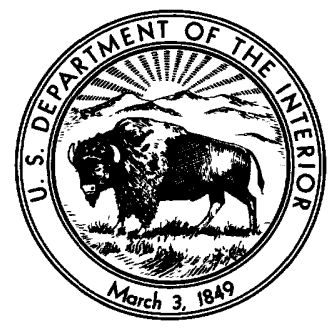

Any use of trade, product, or firm names in this publication is for descriptive purposes only and does not imply endorsement by the U.S. Government

UNITED STATES GOVERNMENT PRINTING OFFICE : 1990

For sale by the

Books and Open-File Reports Section,

U.S. Geological Survey,

Federal Center, Box 25425,

Denver, CO 80225

\section{Library of Congress Cataloging in Publication Data}

Physical environment and geohydrologic effects of surface coal mining in west-central Indiana / by Jeffrey D. Martin ... [et al.].

p. $\quad \mathrm{cm}$. - (U.S. Geological Survey water-supply paper ; 2368A-B)

Includes biblicgraphical references.

Contents: v. 1. Description of the physical environment and coal-mining history of west-central Indiana, with ernphasis on six small watersheds v. 2. Effects of surface coal mining and reclamation on the geohydrology of six small watersheds in west-central Indiana.

1. Coal mines and mining-Environmental aspects-Indiana. 2. Reclamation of land-Environmental aspects-Indiana. 3. Water-pollution-Indiana. 4. Coal mines and mining-Indiana-History. I. Martin, Jeffrey D. II. Series.

TD428.C6P48

$622 \mathrm{~s}-\mathrm{dc} 20$

[333.8'2214]

1990

89-600260 


\section{PREFACE}

Coal has been and will continue to be a major source of energy in the United States for the foreseeable future. Surface mining is presently the most efficient method of extracting coal. This mining practice, however, usually has a detrimental effect on the environment by altering topography and ecologic systems. Surface coal mining also can degrade surface- and ground-water quality and quantity.

In 1977, the United States Congress passed the Surface Mining Control and Reclamation Act (Public Law 95-87), which requires that extensive hydrologic information be collected before granting permits that authorize coal mining. Permit applications must include a description of the quality and quantity of surface- and ground-water resources at and near the proposed mine and an assessment of the probable hydrologic effects of mining. The Act also requires that the regulatory authority, which can be either a State agency or the U.S. Office of Surface Mining, determine the cumulative hydrologic effects of coal mining. Detailed hydrologic information for small watersheds in a coal-mining region is usually sparse.

The U.S. Geological Survey began a study in 1979 to identify changes in the quantity of surface- and ground-water resources caused by surface coal mining in Indiana. As part of this study, six small watersheds in west-central Indiana were instrumented for the collection of hydrologic and meteorologic data. This Water-Supply Paper comprises two reports resulting from this investigation. The physical environment and coal mining history of west-central Indiana and the six small watersheds selected for intensive study are described in chapter A. The surface- and ground-water systems of each of the small watersheds and the hydrologic effects of coal mining and reclamation are described in chapter B. 


\section{CONTENTS}

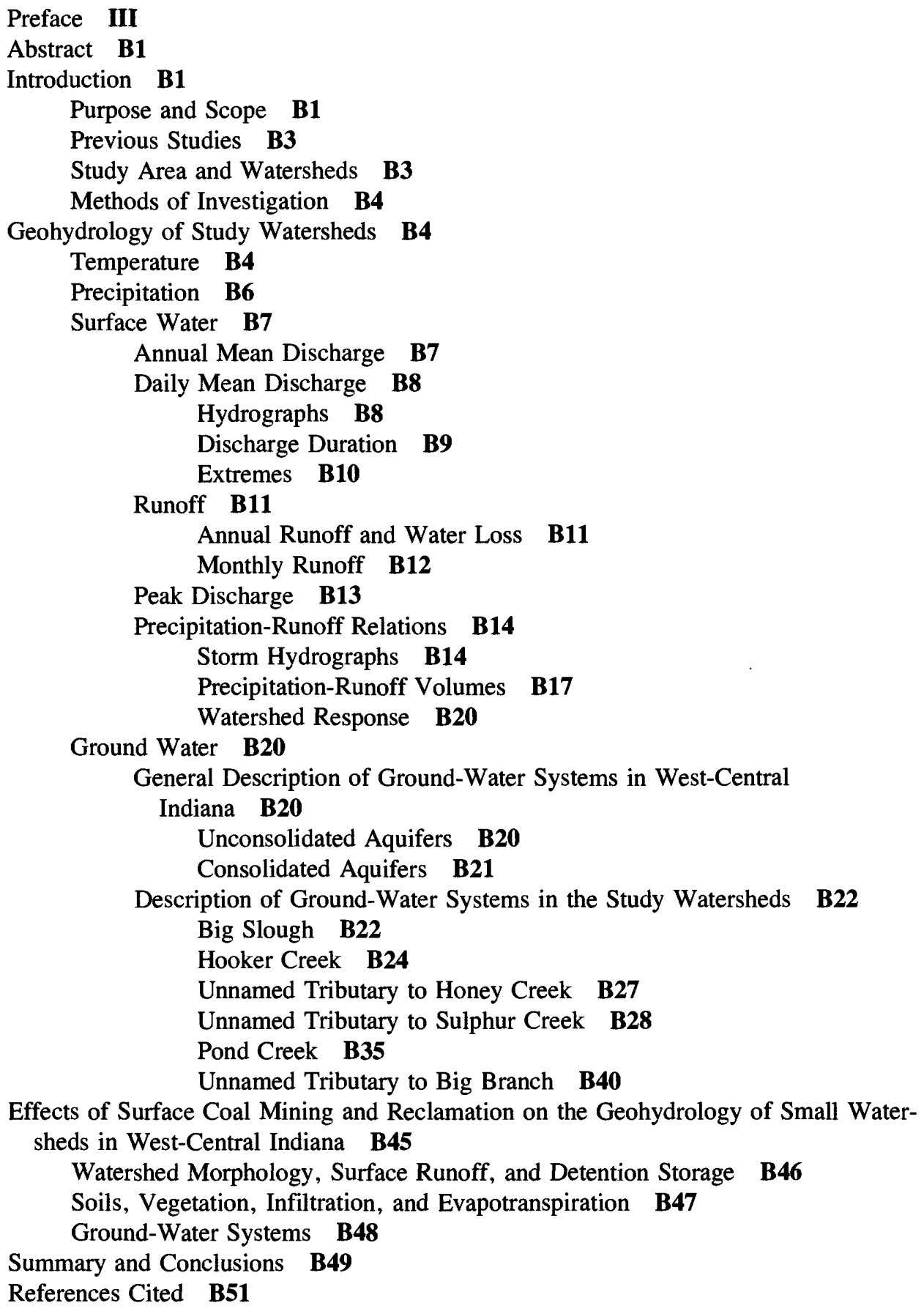

Effects of Surface Coal Mining and Reclamation on the Geohydrology of Small Watersheds in West-Central Indiana B45

Watershed Morphology, Surface Runoff, and Detention Storage B46

Soils, Vegetation, Infiltration, and Evapotranspiration B47

Ground-Water Systems B48

Summary and Conclusions B49

References Cited B51 


\section{FIGURES}

1. Map showing location of six study watersheds and streamflow-gaging stations in Clay, Owen, Sullivan, and Vigo Counties B2

2. Map showing mean annual temperature and mean annual precipitation at climatological stations in and near study area, 1951-80 B5

3-5. Graphs showing:

3. Mean monthly temperature and mean monthly precipitation at Spencer and Terre Haute climatological stations, 1951-80 B6

4. Monthly mean temperature at Daggett, Spencer, and Terre Haute climatological stations, 1981 and 1982 water years B7

5. Daily maximum and minimum temperatures at Daggett climatological station, 1981 and 1982 water years $\mathbf{B 8}$

6. Graphs showing daily mean discharge and daily precipitation at:

A. Big Slough, 1981 and 1982 water years B9

B. Hooker Creek, 1981 and 1982 water years B10

C. Unnamed tributary to Honey Creek, 1981 and 1982 water years B11

D. Unnamed tributary to Sulphur Creek, 1981 and 1982 water years B12

E. Pond Creek, 1981 and 1982 water years B13

$F$. Unnamed tributary to Big Branch, 1981 and 1982 water years B14

7. Graph showing duration curves of daily mean discharge at six study watersheds, 1981 and 1982 water years' B15

8. Graph showing monthly precipitation and runoff at six study watersheds, 1981 and 1982 water years B16

9. Graphs showing instantaneous discharge and accumulated precipitation at six study watersheds for the:

A. Thunderstorm of May 24, 1981 B56

B. Thunderstorm of June 9-10, 1981 B58

C. Thunderstorm of May 29, $1982 \quad \mathbf{B 6 0}$

$D$. Thunderstorm of September 1, $1982 \quad$ B62

E. Frontal storm of May 26-27, 1981 B64

F. Frontal storm of December 21-22, 1981 B66

G. Frontal storm of January 22, $1982 \mathbf{B 6 8}$

H. Frontal storm of April 16-17, $1982 \quad \mathbf{B 7 0}$

10. Map showing Big Slough watershed and data-collection sites $\mathbf{B 2 3}$

11. Graph showing distribution of water levels in nest of wells finished in till at Big Slough, June 17, 1982 B24

12. Map showing altitude of water table at Big Slough, May 18, 1982 B25

13. Graphs showing daily precipitation and ground-water levels at Big Slough, 1981 and 1982 water years B26

14. Hydrogeologic section showing generalized stratigraphy and direction of ground-water flow at Big Slough B27

15. Geologic column showing distribution of water levels in well open to the Linton Formation and well open to the Staunton Formation near Big Slough, June 17, 1982 B28

16. Map showing Hooker Creek watershed and data-collection sites $\mathbf{B 2 9}$

17. Map showing unnamed tributary to Honey Creek watershed and datacollection sites B30

18. Graphs showing daily precipitation and daily mean ground-water levels at unnamed tributary to Honey Creek, 1981 and 1982 water years B31

19-21. Maps showing:

19. Altitude of water table at unnamed tributary to Honey Creek, August 20, 1981 B32 
20. Altitude of water table at unnamed tributary to Honey Creek, May 19, 1982 B33

21. Unnamed tributary to Sulphur Creek watershed and data-collection sites B34

22. Hydrogeologic section showing generalized stratigraphy and direction of ground-water flow at unnamed tributary to Sulphur Creek B36

23. Map showing altitude of water table at unnamed tributary to Sulphur Creek, July $15,1982 \quad$ B37

24. Graphs showing daily precipitation and daily mean lake and ground-water levels at unnamed tributary to Sulphur Creek, 1981 and 1982 water years B38

25. Graphs showing distributions of water levels in nest of wells finished in reclaimed mine spoil or bedrock at unnamed tributary to Sulphur Creek B39

26. Geologic column showing distribution of water levels in well screened in till, well open to the Dugger Formation, and well open to the Dugger and Petersburg Formations at unnamed tributary to Sulphur Creek, September 7, 1982 B40

27. Map showing Pond Creek watershed and data-collection sites B41

28. Hydrogeologic section showing generalized stratigraphy and direction of ground-water flow at Pond Creek B42

29. Graphs showing daily precipitation and daily mean discharge and groundwater levels at Pond Creek, 1981 and 1982 water years B43

30. Map showing unnamed tributary to Big Branch watershed and data-collection sites B44

31. Graphs showing daily precipitation and daily mean lake and ground-water levels at unnamed tributary to Big Branch, 1981 and 1982 water years

\section{TABLES}

1. Annual precipitation and annual mean discharge at six study watersheds B9

2. Extremes of daily mean discharge at six study watersheds B18

3. Annual runoff and annual water loss at six study watersheds B18

4. Instantaneous peak discharge at six study watersheds B19

5. Volumes of precipitation and runoff and times from beginning of rise to peak discharge at six study watersheds for the:

A. Thunderstorm of May 24, 1981 B57

B. Thunderstorm of June 9-10, 1981 B59

C. Thunderstorm of May 29, 1982 B61

D. Thunderstorm of September 1, $1982 \quad \mathbf{B 6 3}$

E. Frontal storm of May 26-27, 1981 B65

$F$. Frontal storm of December 21-22, $1981 \quad$ B67

$G$. Frontal storm of January 22, $1982 \quad$ B69

H. Frontal storm of April 16-17, 1982 B71

6. Hydraulic conductivity of till, spoil, and bedrock for six study watersheds 


\section{METRIC CONVERSION FACTORS}

For readers who wish to convert measurements from the inch-pound system of units to the metric system of units, the conversion factors are listed below:

\begin{tabular}{rcl}
\hline Multiply inch-pound unit & By & To obtain SI units \\
inch (in.) & 25.4 & millimeter $(\mathrm{mm})$ \\
foot $(\mathrm{ft})$ & .3048 & meter $(\mathrm{m})$ \\
mile $(\mathrm{mi})$ & 1.609 & kilometer $(\mathrm{km})$ \\
square foot $\left(\mathrm{ft}^{2}\right)$ & .09290 & square meter $\left(\mathrm{m}^{2}\right)$ \\
square mile $\left(\mathrm{mi}^{2}\right)$ & 2.590 & square kilometer $\left(\mathrm{km}^{2}\right)$ \\
acre-foot $(\mathrm{acre}-\mathrm{ft})$ & 1,233 & cubic meter $\left(\mathrm{m}^{3}\right)$ \\
inch per year (in $/ \mathrm{yr})$ & 2.54 & centimeter per year $(\mathrm{cm} / \mathrm{yr})$ \\
foot per day $(\mathrm{ft} / \mathrm{d})$ & .3048 & meter per day $(\mathrm{m} / \mathrm{d})$ \\
cubic foot per second per square & .01093 & cubic meter per second per square kilo- \\
mile $\left.[(\mathrm{ft} / 3) / \mathrm{s}) / \mathrm{mi}^{2}\right]$ & & meter $\left[\left(\mathrm{m}^{3} / \mathrm{s}\right) / \mathrm{km}{ }^{2}\right]$ \\
gallon per minute $(\mathrm{gal} / \mathrm{min})$ & 3.785 & liter per minute $(\mathrm{L} / \mathrm{min})$ \\
degree Fahrenheit $\left({ }^{\circ} \mathrm{F}\right)$ & $5 / 9\left({ }^{\circ} \mathrm{F}-32\right)$ & degree Celsius $\left({ }^{\circ} \mathrm{C}\right)$ \\
\hline
\end{tabular}

\section{ALTITUDE DATUM}

National Geodetic Vertical Datum of 1929 (NGVD of 1929): A geodetic datum derived from a general adjustment of the first-order level nets of both the United States and Canada, formerly called Sea Level Datum of 1929. 


\title{
Effects of Surface Coal Mining and Reclamation on the Geohydrology of Six Small Watersheds in West-Central Indiana
}

\author{
By Jeffrey D. Martin, Richard F. Duwelius, and Charles G. Crawford
}

\begin{abstract}
Six small watersheds in west-central Indiana were selected for study of the hydrologic effects of surface coal min ing and reclamation. The watersheds include mined and reclaimed, mined and unreclaimed, and unmined agricultural land uses and are each less than 3 square miles in area. Surface-water, ground-water, and meteorologic data for the 1981 and 1982 water years were used to describe and compare hydrologic systems of the six watersheds and to identify hydrologic effects of mining and reclamation.
\end{abstract}

Discharge at the unreclaimed watersheds was continuous during the study period, whereas discharge at the other watersheds was intermittent and more variable. Peak discharges were greater at the agricultural watersheds than at the unreclaimed watersheds, primarily because of large final-cut lakes in the unreclaimed watersheds. Annual runoff was greatest at the unreclaimed watersheds, intermediate at the agricultural watersheds, and least at the reclaimed watersheds.

Hydrologic effects of mining were identified by comparing the hydrologic systems at mined and unreclaimed watersheds with those at unmined agricultural watersheds. These comparisons indicate that surface coal mining without reclamation can increase base flow, annual runoff, and ground-water recharge to the bedrock; reduce peak flow rates and variation in flow; lower the water table in upland areas; change the relation between surface- and ground-water divides; and create numerous, local flow systems in the shallow ground water.

Hydrologic effects of reclamation were identified by comparing the hydrologic systems at mined and reclaimed watersheds with those at mined and unreclaimed watersheds. Reclamation can decrease base flow, annual runoff, and recharge to the bedrock; increase peak flow rates, variation in flow, and the response to thunderstorms; reestablish the premining relation between surface- and ground-water divides; and create fewer local flow systems in the shallow ground water.

Manuscript approved for publication March 26, 1987.
Hydrologic effects of mining and reclamation were identified by comparing the hydrologic systems at mined and reclaimed watersheds with those at unmined agricultural watersheds. The presence or absence of a large final-cut lake in the reclaimed watershed greatly influences the hydrologic systems and the effects of mining and reclamation. Surface coal mining and reclamation can decrease base flow, annual runoff, and peak flow rates; increase the variability of flow and recharge to th - bedrock; reestablish the premining relation between surfaceand ground-water divides; and lower the water table in upland areas.

\section{INTRODUCTION}

\section{Purpose and Scope}

This report (1) describes and compares the surfaceand ground-water systems of six small watershed in the coal-mining region of Indiana, (2) identifies and diccusses the effects of surface coal mining and reclamatior on the geohydrology of these six watersheds, and (3) discusses potential geohydrologic effects of mining and recl'mation on small watersheds in west-central Indiana. The study watersheds include mined and reclaimed, mined and unreclaimed, and unmined agricultural land uses and are each less than $3 \mathrm{mi}^{2}$ (square miles) in area (fig. 1). A con inuousrecord streamflow-gaging station, at least one con'inuousrecord precipitation gage, and at least one con+inuousrecord ground-water well were installed in or near each watershed. One climate station was established at Daggett in the vicinity of the six watersheds (fig. 1). Forty-seven wells finished in unconsolidated deposits and 20 wells finished in bedrock were installed in or near the wat

Hydrologic and meteorologic data for the 1981 and 1982 water years are used to describe the surface- and ground-water systems of the study watersheds. Temperature and precipitation data are compared to 30-year averages (1951-80). Annual, daily, and instantaneous discharge characteristics are compared between water years and 


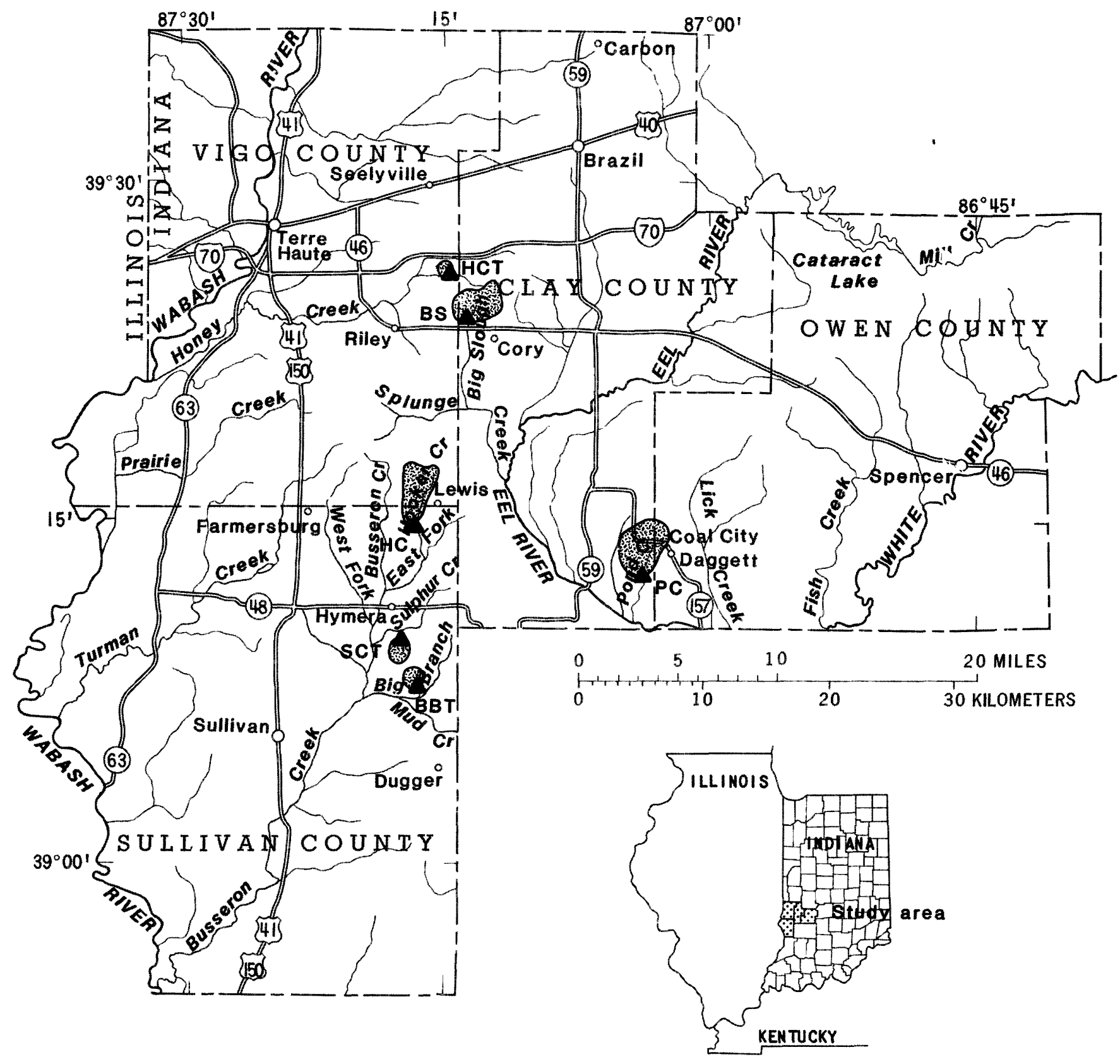

EXPLANATION

$\begin{array}{ll}\triangle \text { BS } & \text { Big Slough near Cory } \\ \text { HC } & \text { Hooker Creek near Lewis } \\ \triangle \text { HCT } & \text { Unnamed tributary to Honey Creek near Cory }\end{array}$

$\triangle$ SCT Unnamed tributary to Sulphur Creek near Hymera

$\triangle P C \quad$ Pond Creek near Coal City

$\triangle$ BBT Unnamed tributary to Big Branch near Hymera

Watershed

Figure 1. Location of six study watersheds and streamflow-gaging stations $(\boldsymbol{\Delta})$ in Clay, Owen, Sullivan, and Vigo Counties.

among watersheds. Precipitation-runoff relations are compared on annual, monthly, and storm-event time intervals. Unconsolidated and bedrock aquifers, flow systems, and ground-water-surface-water relations are de:cribed. Differences and similarities in the surface- and ground-water systems at these six watersheds are used tc infer potential 
hydrologic effects of surface coal mining and reclamation on small watersheds in west-central Indiana. Surface- and ground-water quality are not discussed.

\section{Previous Studies}

Most studies of the hydrologic effects of surface coal mining in Indiana emphasized the effects of mining on water quality, primarily surface-water quality (Corbett and Agnew, 1968; Corbett, 1969; Wilber and others, 1980, 1985; Peters, 1981; Wangsness and others, 1981a,b, 1983; Zogorski and others, 1981; Wangsness, 1982; Wilber and Boje, 1982). Few studies attempted to investigate the effects of mining on the quantity of water. A summary of some studies on the effects of surface coal mining on water quantity in the Interior and Appalachian Coal Provinces follows.

The U.S. Geological Survey conducted one of the first studies of the hydrologic effects of surface coal mining in the rugged, forested terrain of the Beaver Creek watershed in eastern Kentucky (Collier and others, 1970). Runoff characteristics from 1955 to 1966 for two small watersheds (less than $1 \mathrm{mi}^{2}$ ) were compared. Peak flows were greater in the watershed containing 10.4 percent mined land than in the unmined watershed. The unmined watershed had greater magnitude and duration of low flows. Annual totals and monthly distributions of runoff were similar for both watersheds. Water impoundments created by mining provided recharge to ground water in the mine spoil.

Curtis (1978) studied the effects of mining and reclamation on the hydrology of small, mountain watersheds in eastern Kentucky and western West Virginia. Peak flow rates were three to five times greater in active or recently mined watersheds than in unmined forested watersheds. Data from these same watersheds showed that peak flow rates in mined watersheds after reclamation were less than those from unmined watersheds. Curtis (1978) attributed the reduction in peak flows to the establishment of vegetation on the reclaimed mine spoil.

Brabets (1984) compared the surface-water characteristics of seven small watersheds (1.46 to $\left.18.4 \mathrm{mi}^{2}\right)$ in Illinois and concluded that mined and unreclaimed watersheds have greater base flows and less flow variation than unmined agricultural watersheds. In addition, unreclaimed watersheds have lower peak discharges, lower storm runoff volumes, less runoff during wet months, and more runoff during dry months than unmined agricultural watersheds.

The first study of the hydrologic effects of mining in Indiana was conducted in the Patoka River watershed, an extensively mined, unglaciated area in southwestern Indiana. Corbett (1965) measured the flow in numerous streams during the summer and fall drought of 1964 and found that streams draining mined areas had flow, whereas those draining similar or larger unmined areas were dry. Water- sheds that had flow ranged from 0.5 to $71 \mathrm{mi}^{2}$ in size, and surface mined areas constituted 8.7 to 86.7 percent of the watershed area. Corbett (1965) concluded that min spoil has a large capacity to store water and that the storage capacity of spoil may reduce flood flows, as well as increase base flows.

The effects of mining on the hydrology of small watersheds are inconsistent between coal provinces but show regional similarities. In the forested, steep terrain of eastern Kentucky and western West Virginia, mining increased peak flows and decreased base flows, whereas in the flatter, agricultural coal fields of Illinois and Indiana, mining decreased peak flows and increased base flows. The discrepancy in results illustrates the need for site-snecific information and the hazards of extrapolating conclusions from one area to another.

\section{Study Area and Watersheds}

Clay, Owen, Sullivan, and Vigo Counties constitute the study area in west-central Indiana (fig. 1). The study area contains Pennsylvanian bedrock, which is covered by Illinoian till. Landforms are predominantly wide, flat flood plains in the lowland areas and broad, rolling plain in the $^{2}$ upland areas. Soils are deep and are very slowly to moderately permeable. Precipitation averages abo'st 39.5 in/yr (inches per year), about one-third of which run" off as streamflow. Outwash and alluvium are the principal sources of ground water in the area, although some wells in till or bedrock supply enough water for domestic use. Most of the land is used for agriculture, primarily row-crop corn and soybeans or pasture. A description of the geology, geomorphology, soils, climate, hydrology, water use, land use, population, and coal-mining history of the study area is given in Martin and others (1990).

Six watersheds were selected to compare the hydrologic systems of mined and unmined watershets. All watersheds are located within a 12-mi (mile) radius (fig. 1). The proximity of the watersheds minimizes variations in weather, geology, soils, and other physical contitions. Small watersheds were selected because most coal i^ mined in small watersheds and because information on the hydrology of small watersheds is scarce. Two of the sir watersheds were selected as controls and represent agricultural land use, the most common land use in the study area. The remaining four watersheds represent types of mined watersheds that occur in Indiana, both reclaimed ant unreclaimed. Detailed information on the morphology, geology, soils, land use, and coal-mining history of each study watershed is given in Martin and others (1990). A brief description of each watershed follows.

Big Slough and Hooker Creek are streams trat drain unmined agricultural watersheds (fig. 1). Row-crop corn and soybeans are the principal crops. Soils are moterately 
well-drained silt loams, and the watersheds have welldeveloped dendritic drainage systems.

The unnamed tributary to Honey Creek and the unnamed tributary to Sulphur Creek are streams that drain mined and reclaimed watersheds (fig. 1). Ridges of mine spoil have been graded to a gently rolling topography. Soils are well drained and consist of 6 to 12 in. (inches) of silt-loam topsoil that was stockpiled and then replaced over shale and sandstone fragments of the graded mine spoil. Both watersheds are beginning to develop incised drainage systems. The watershed of the unnamed tributary to Sulphur Creek contains a final-cut lake at the outlet of the watershed. A final-cut lake results when the last pit in a coal mine is not filled with spoil and graded to a somewhat level topography but is allowed to fill with water. Grasses and legumes form the vegetative cover in each watershed. The vegetative cover is dense at the watershed of the unnamed tributary to Sulphur Creek and is sparse at the watershed of the unnamed tributary to Honey Creek.

Pond Creek and the unnamed tributary to Big Branch are streams that drain mined and unreclaimed watersheds (fig. 1). Approximately one-half of the Pond Creek watershed is unmined agricultural or forested land. Soils are very well-drained, shaly silty loams that have formed on steeply sloping spoil banks. Both watersheds contain numerous impoundments of water from past surface mining. Drainage systems are complex and have many enclosed areas that do not contribute surface runoff to streamflow. The ridges of mine spoil are covered with pine trees, but the surface of the spoil is mostly devoid of vegetation.

To reduce wordiness and repetition, the word "unnamed" has been dropped from the stream and watershed names. For example, the unnamed tributary to Sulphur Creek is hereafter referred to in the text as Sulphur Creek tributary. The name refers to either the stream or watershed, depending on the context of use. References to the watershed in the report refer to the drainage areas above the gaging stations. The full names are used in the tables and figures. Further, to remind the reader of the predominant land use in each watershed, a short identifier follows the watershed name in the tables and figures and at selected places in the text. The land-use identifiers are (Unmined), unmined agriculture; (Reclaimed), mined and reclaimed; and (Unreclaimed), mined and unreclaimed.

\section{Methods of Investigation}

Temperature and other meteorological variables were measured from October 1980 to June 1983 at the climatological station established for the study in Daggett (fig. 1). Precipitation and discharge were measured in the six watersheds at 5-minute intervals from October 1980 to June 1983. Discharge at Big Branch tributary was measured at 15-minute intervals. At least one continuous-record, float- type rain gage was installed in or near each watershed. Big Slough and Hooker Creek were equipped with two rain gages. Continuous-record discharge gages were installed on each stream. The gaging stations at Big Slough (03360109 Big Slough near Cory), Hooker Creek (03342110 Hooker Creek near Lewis), and Pond Creek (03360125 Pond Creek near Coal City) are located on the stream banks and have natural controls. V-notch weirs were installed at the outlets of final-cut lakes in Sulphur Creek tributary (03342167 Unnamed tributary to Sulphur Creek near $\mathrm{H}^{*}$ mera) and Big Branch tributary (03342219 Unnamed tributary to Big Branch near Hymera). A Parshall flume vas installed at Honey Creek tributary (03341568 Unnam:d tributary to Honey Creek near Cory).

Twenty wells were installed in bedroc ${ }^{\mathrm{r}}$, and 47 wells were installed in unconsolidated deposits. Wells installed in bedrock were drilled by using mud-rotary methods, cased with 5-in.-diameter polyvinyl chloride casing, and sealed. The remainder of the hole was airhammered and left open. Wells installed in unconsolidated deposits were drilled with a hollow-stem auger, 2-in.- and 4-in.-diameter casings and screens were set, and the holes were backfilled with pea gravel around the screen or drill cuttings for the remainder of the hole. Water levels were measured cortinuously at 11 wells from December 1980 to May 1983 and were measured intermittently at 56 wells from October 1987 to September 1983. Daily hydrologic and meteorological data and a complete description of the instrumentation and methods of data collection are given in Renn and other: (1985).

Hydraulic conductivities given in this report were estimated from slug tests by using the method of Bouwer and Rice (1976, p. 424-425). Values of hydraulic conductivity from this method compared favorably with those from the methods of Skibitzke (1958) and Cooner and others (1967).

Although data were collected for pat of the 1983 water year, only data collected during the 1981 and 1982 water years were analyzed in this report. A water year is a 12-month period that begins October 1 and ends September 30 and is named for the calendar year in which it ends (Langbein and Iseri, 1960, p. 21). For example, the 1981 water year is the period October 1, 1980, through September 30,1981 .

\section{GEOHYDROLOGY OF STUDY WATERSHEDS}

\section{Temperature}

Air temperature is measured at eight National Weather Service climatological stations in and near the study area (fig. 2). The Bowling Green and Elliston climatological stations do not measure temrerature. Mean 


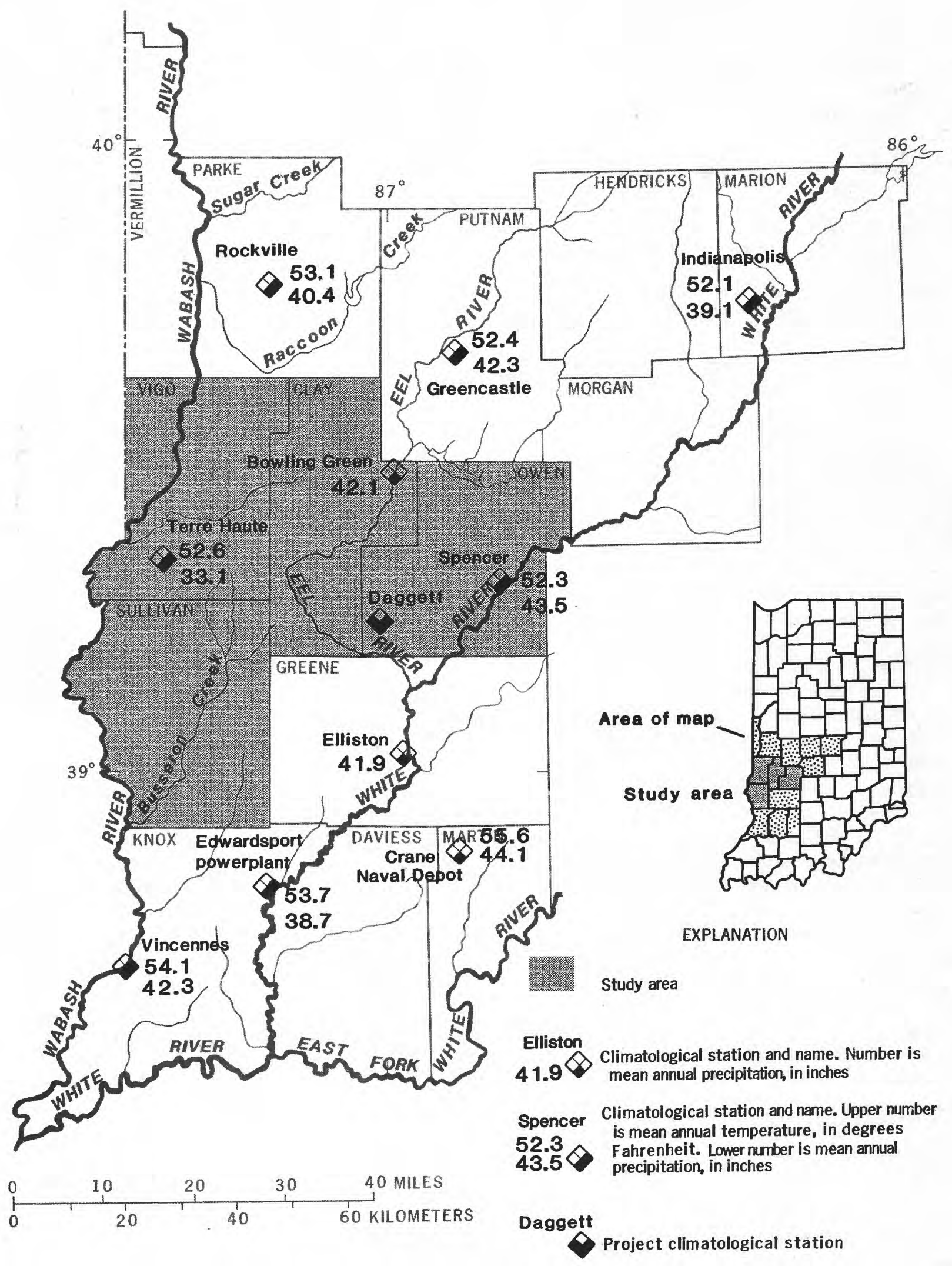

Figure 2. Mean annual temperature and mean annual precipitation at climatological stations in and near study area, 1951-80. Data from U.S. Department of Commerce, 1982a. 

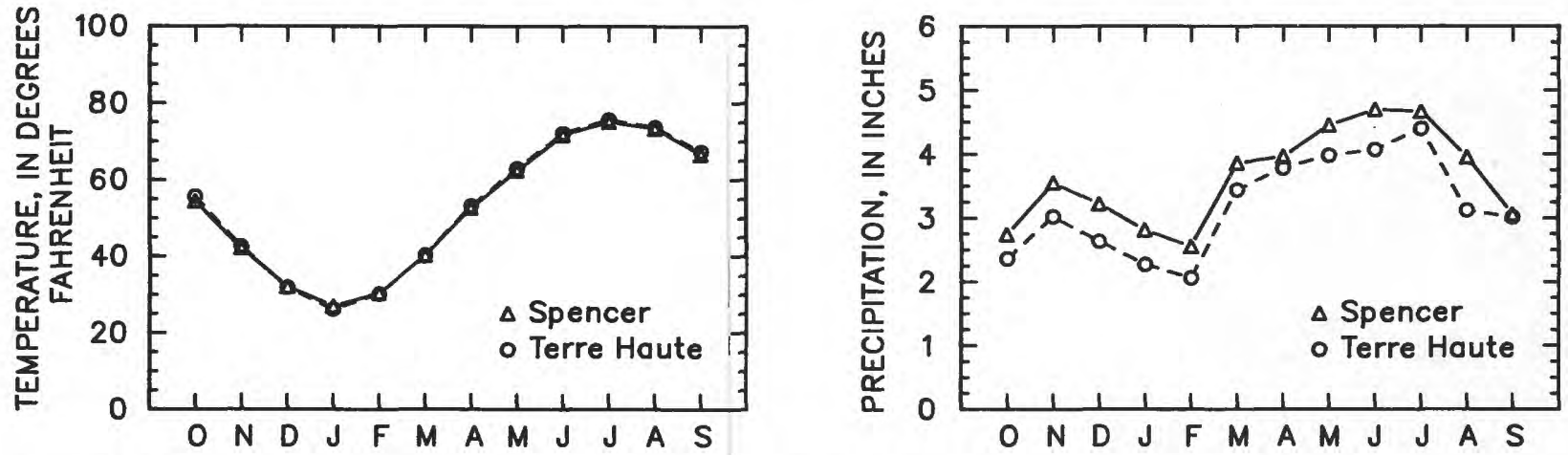

Figure 3. Mean monthly temperature and mean monthly precipitation at Spencer and Terre Haute climatological stations, 1951-80. Data from U.S. Department of Commerce, 1982a.

annual temperature for the 30-year period 1951-80 ranged from $52.1^{\circ} \mathrm{F}$ (degrees Fahrenheit) at Indianapolis to $55.6^{\circ} \mathrm{F}$ at Crane Naval Depot. The average of the mean annual temperature at the eight climatological stations shown in figure 2 is $53.2^{\circ} \mathrm{F}$. January is usually the coldest month, and July is usually the warmest month (fig. 3 ).

Annual mean temperature at Daggett was $51.8^{\circ} \mathrm{F}$ for the 1981 water year and $50.1^{\circ} \mathrm{F}$ for the 1982 water year. Both water years were cooler than the 30 -year mean annual temperature at the climatological stations in and near the study area. Annual mean temperature at the eight climatological stations ranged from 51.2 to $55.5^{\circ} \mathrm{F}$ for the 1981 water year and from 50.0 to $54.0^{\circ} \mathrm{F}$ for the 1982 water year. Annual mean temperature was warmer during the 1981 water year than the 1982 water year at all climatological stations.

Monthly mean temperatures for December, January, February, April, and June during the 1982 water year were substantially colder than during the 1981 water year (fig. 4). Monthly mean temperature for May during the 1982 water year was substantially warmer than during the 1981 water year. Monthly mean temperatures for the remaining months were approximately the same for both water years. January, April, and June of the 1982 water year were markedly colder than the 30-year mean monthly temperatures (figs. $3,4)$.

Freezing temperatures occurred from late October to late March in the water year 1981 and from late October to mid-April in the 1982 water year (fig. 5). Frequent periods of thawing occurred during both winters.

\section{Precipitation}

Mean annual precipitation at 10 National Weather Service climatological stations in and near the study area ranged from $38.1 \mathrm{in}$. at Terre Haute to $44.1 \mathrm{in}$. at Crane Naval Depot during the period 1951-80 (fig. 2). No pattern is apparent in the distribution of mean annual precipitation.
The average of the mean annual precipitation at the 10 climatological stations was 41.3 in.

Precipitation at Spencer and Terre Haute climatological stations is fairly evenly distributed throughout the year, and there are adequate amounts during the growing season (fig. 3). Monthly precipitation is usually greatest in June or July and is usually least in February, January, or October. Mean monthly precipitation is about 0.5 in. more at Spencer than at Terre Haute.

Annual precipitation in the study watersheds ranged from 31.4 to $41.4 \mathrm{in}$. for the 1981 water year and from 36.8 to 49.2 in. for the 1982 water year (see table 1). The large ranges illustrate the spatial variability of precipitation. Even in watersheds having two rain gages, the difference in annual precipitation at the two gages ranged from 0.5 to 3.8 in. For watersheds having two rain gages, the average precipitation measured at the two rain gages is used as the best estimate of precipitation in that watershed.

All the watersheds except the Honey Creek tributary watershed received more precipitation in the 1982 water year than in the 1981 water year (table 1). Annual precipitation for the 1981 water year in the six study watersheds was generally less than the 30 -year mean (41.3 in.), but annual precipitation for the 1982 water year was generally greater than the 30 -year mean. Annual precipitation at the 10 climatological stations ranged from 34.7 to 48.8 in. (average $43.4 \mathrm{in}$.) for the 1981 water year and from 38.0 to 52.1 in. (average $46.9 \mathrm{in}$.) for the 1982 water year (U.S. Department of Commerce, 1980-82).

Monthly precipitation at each of the six watersheds was greatest in May and least in January for the 1981 water year and was greatest in May (July at Big Slough) and least in October or November for the 1982 water year (see fig. 8). The 1981 water year was significantly drier in December, January, and March but was wetter in April and May than the 1982 water year. July and September were generally drier in the 1981 water year than in the 1982 water year, 
DAGGETT

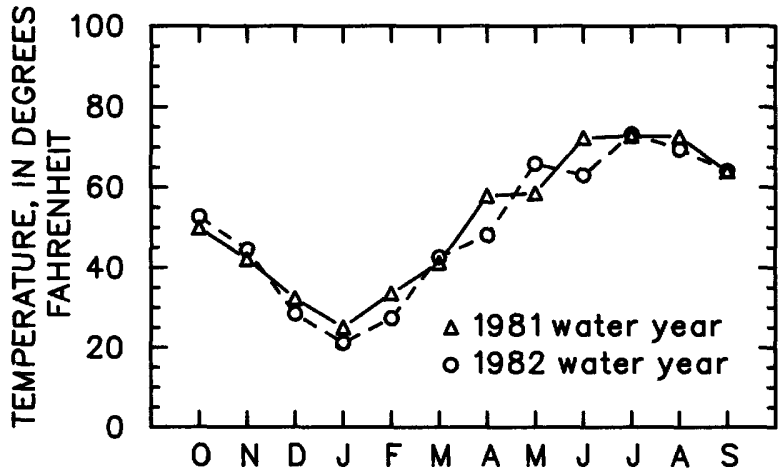

TERRE HAUTE

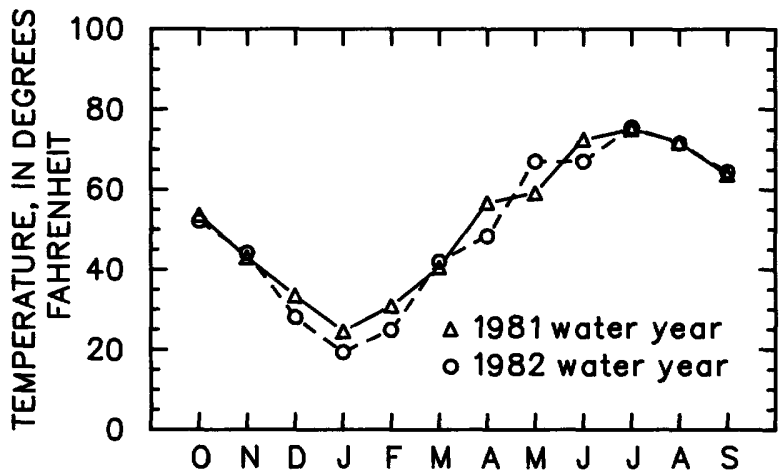

SPENCER

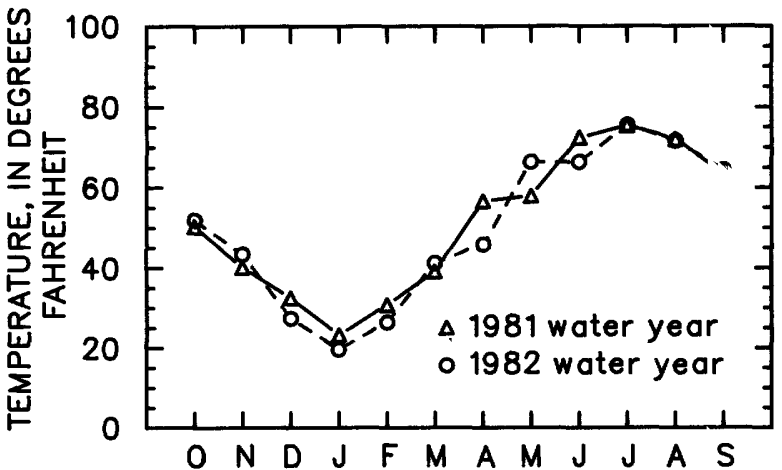

Figure 4. Monthly mean temperature at Daggett, Spencer, and Terre Haute climatological stations, 1981 and 1982 water years. Data for Spencer and Terre Haute from U.S. Department of Commerce, 1980-82.

but this trend was not observed at all watersheds because of the variability of thunderstorms.

Record snowfall (58.2 in.) was measured at the Indianapolis climatological station from November 1981 to April 1982 (U.S. Department of Commerce, 1982b). Mean annual snowfall at Indianapolis is 22.9 in. (U.S. Department of Commerce, 1982b). A significant snow cover at the watersheds was verified by several field visits during the winter of the 1982 water year. Although a snow cover was also present during the 1981 water year, the cover was not as frequent or as deep as that during the 1982 water year.

Somewhat similar patterns of occurrence and magnitude of daily precipitation are apparent at each of the six watersheds (see fig. 6).

\section{Surface Water}

The flow of water can be described by a variety of technical terms and expressed in many different units of measure (Langbein and Iseri, 1960; U.S. Geological Survey, 1977, p. 1-4, 1-5). The distinction among terms often is subtle and can lead to confusion. In this report, runoff is used to describe the yield of a watershed and is expressed as inches of water over the watershed. Discharge is used to describe the flow rate measured at the gage and is expressed in cubic feet per second per square mile $\left[\left(\mathrm{ft}^{3} / \mathrm{s}\right) / \mathrm{mi}^{2}\right]$ to compare watersheds of different sizes. Expressing discharge on an area basis is useful for comparing different size watersheds but is not entirely without comnromise. Peak discharge per area commonly is inversely pronortional to watershed area (Gregory and Walling, 1973, p. 197).

\section{Annual Mean Discharge}

Annual mean discharge at the six watersheds ranged from 0.433 to $1.83\left(\mathrm{ft}^{3} / \mathrm{s}\right) / \mathrm{mi}^{2}$ for water years 1981 and 1982 (table 1). For the 1981 water year, Pond Creek and Big Branch tributary had the largest annual mean discharge, Honey Creek tributary and Sulphur Creek tributar: had the smallest, and Big Slough and Hooker Creek had intermediate annual mean discharge. Groupings based on annual mean discharge for the 1982 water year were somewhat different. Honey Creek tributary still had the smallest discharge, Big Branch tributary still had the largest discharge, but the annual mean discharge at Sulphur Creek tributary and Pond Creek were more similar to thcse at Big Slough and Hooker Creek (table 1).

Annual mean discharge was associated with annual precipitation to the extent that, for each watershed, the 


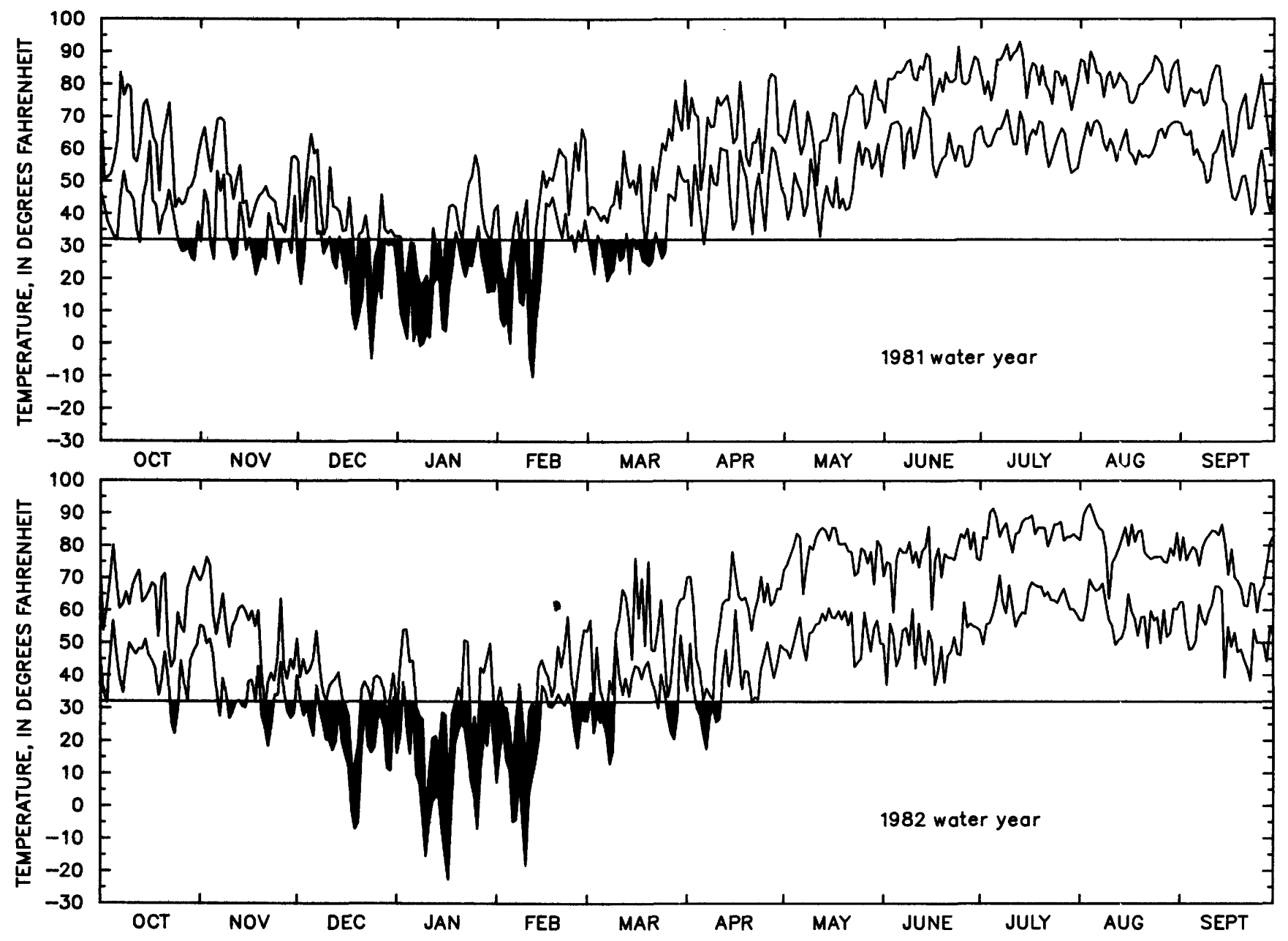

Figure 5. Daily maximum and minimum temperatures at Daggett climatological station, 1981 and 198 ? water years. Temperatures at or below freezing are shaded.

water year having the greatest mean discharge also was the water year having the greatest precipitation. However, linear regression using data from all watersheds failed to find a statistically significant relation between annual mean discharge and annual precipitation. Lack of a significant relation indicates that differences in annual mean discharge are not entirely explained by differences in annual precipitation.

\section{Daily Mean Discharge}

\section{Hydrographs}

Similar patterns of high flows (discharge) among the watersheds result from similar patterns of precipitation and other climatic influences (fig. 6). Similarities are especially evident during periods of regional frontal storms (November through May) and snowmelt (January through March). Patterns of peak flows from June through September are less similar because of the spatial variability of thunderstorms. Flows typically are greatest at Big Slough and Hooker Creek and are least at Big Branch tributary.

Major differences among the watersheds are evident in low flows and in hydrograph shape. Pond Creek and Big Branch tributary continually flow. The otl $\mathrm{s}$ watersheds had times of no flow during both water years. The recession limbs of the hydrographs for Sulphur Creek tributary, Pond Creek, and Big Branch tributary are more extended than those for the other watersheds (fig. 6). The extended recession limbs graphically illustrate that, after a storm, runoff decreases at a much slower rate at Sulphur Creek tributary, Pond Creek, and Big Branch tribu'ary than at the other watersheds. The extended recessions probably are associated with the final-cut lakes and other vater impoundments that collect and delay surface runoff in these watersheds. Additional information on zero flow and hydrograph shape is contained in the sections Extremes and Watershed Response. 


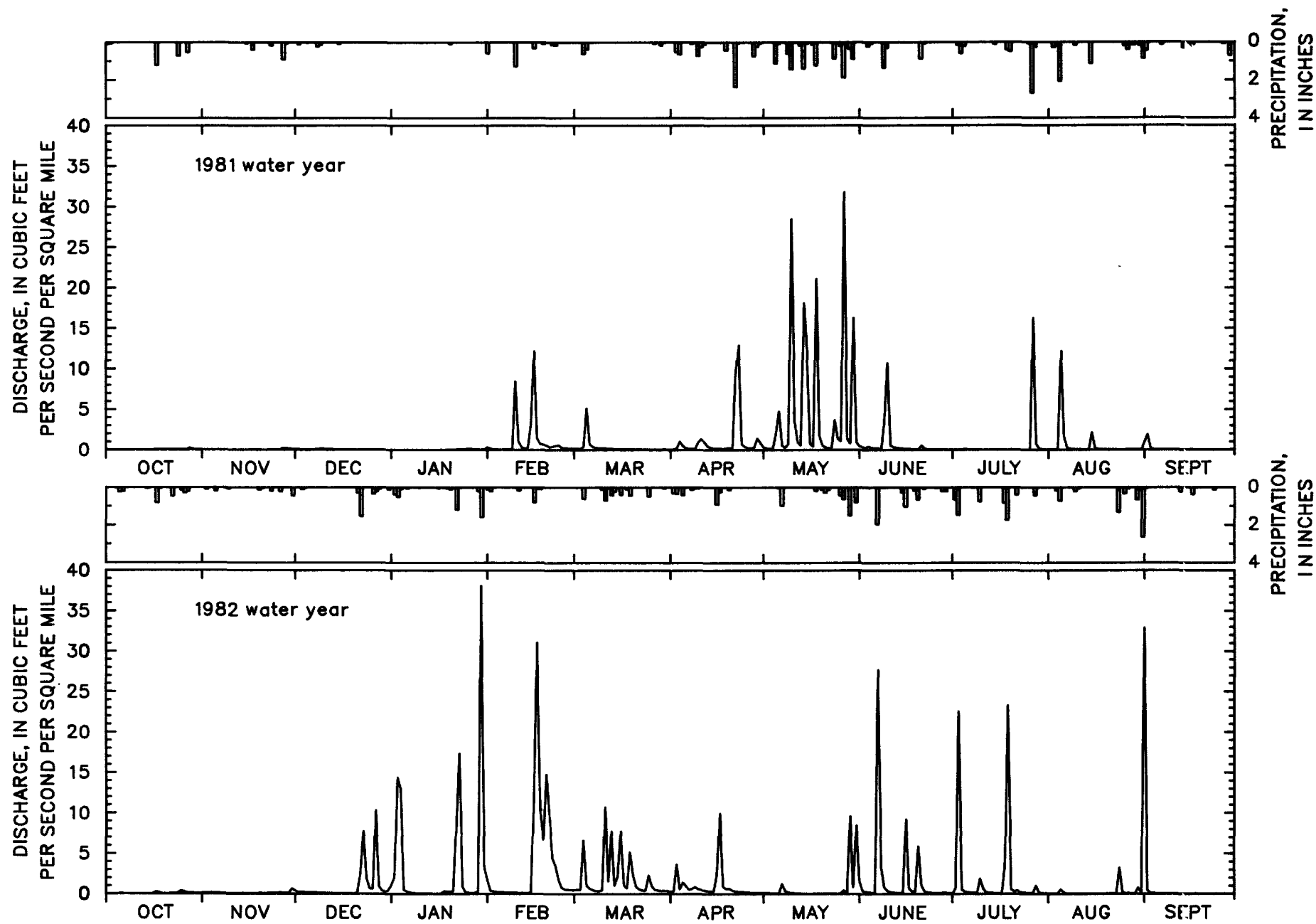

Figure 6A. Daily mean discharge and daily precipitation at Big Slough, 1981 and 1982 water years.

Table 1. Annual precipitation and annual mean discharge at six study watersheds $\left[\mathrm{mi}^{2}\right.$, square mile; in., inch; $\left(\mathrm{ft}^{3} / \mathrm{s}\right) / \mathrm{mi}^{2}$, cubic feet per second per square mile]

\begin{tabular}{|c|c|c|c|c|c|}
\hline \multirow[b]{2}{*}{ 'Watershed } & \multirow[b]{2}{*}{$\underset{\left(\mathrm{mi}^{2}\right)}{\text { Drainage area }}$} & \multicolumn{2}{|c|}{ Annual precipitation (in.) } & \multicolumn{2}{|c|}{ Annual mean discharge $\left.{ }^{1}\left(\mathrm{ft}^{3} / \mathrm{s}\right) / \mathrm{mi}^{2}\right]$} \\
\hline & & 1981 water year & 1982 water year & 1981 water year & 1982 water year \\
\hline $\begin{array}{l}\text { Big Slough (Unmined) } \ldots \ldots \ldots \ldots \ldots \ldots \\
\text { Hooker Creek (Unmined) } \ldots \ldots \ldots \ldots \ldots\end{array}$ & $\begin{array}{l}2.70 \\
2.72\end{array}$ & $\begin{array}{l}41.4 \\
36.5\end{array}$ & $\begin{array}{l}42.1 \\
46.1\end{array}$ & $\begin{array}{r}0.809 \\
.871\end{array}$ & $\begin{array}{l}1.38 \\
1.28\end{array}$ \\
\hline $\begin{array}{l}\text { Unnamed tributary to Honey Creek } \\
\text { (Reclaimed) } \ldots \ldots \ldots \ldots \ldots \ldots \ldots \ldots\end{array}$ & .11 & 37.3 & 36.8 & .448 & .433 \\
\hline $\begin{array}{l}\text { Unnamed tributary to Sulphur Creek } \\
\text { (Reclaimed) } \ldots \ldots \ldots \ldots \ldots \ldots \ldots \ldots \\
\text { Pond Creek (Unreclaimed) } \ldots \ldots \ldots \ldots\end{array}$ & $\begin{array}{r}.21 \\
1.97\end{array}$ & $\begin{array}{l}31.4 \\
39.1\end{array}$ & $\begin{array}{l}44.1 \\
49.2\end{array}$ & $\begin{array}{l}.556 \\
1.11\end{array}$ & $\begin{array}{l}1.12 \\
1.44\end{array}$ \\
\hline $\begin{array}{l}\text { Unnamed tributary to Big Branch } \\
\text { (Unreclaimed) } \ldots \ldots \ldots \ldots \ldots \ldots \ldots\end{array}$ & .32 & 35.8 & 39.8 & 1.30 & 1.83 \\
\hline
\end{tabular}

${ }^{1}$ Annual mean discharge is the average of 365 daily mean discharges.

\section{Discharge Duration}

Discharge-duration curves are cumulative frequency curves that show discharges that are equaled or exceeded a certain percentage of the time. The slope of the curve indicates the variability of flow. Steeply sloping curves indicate highly variable discharge, whereas moderately sloping curves indicate relatively stable discharge. Duration curves (fig. 7) were calculated from 730 daily mean discharges during the 1981 and 1982 water years for the six study watersheds.

Two groups of curves in figure 7 are apparent on the basis of slope and the point where each curve intersects (or fails to intersect) the $x$-axis. Duration curves for Pond Creek and Big Branch tributary indicate that discharge was con- 


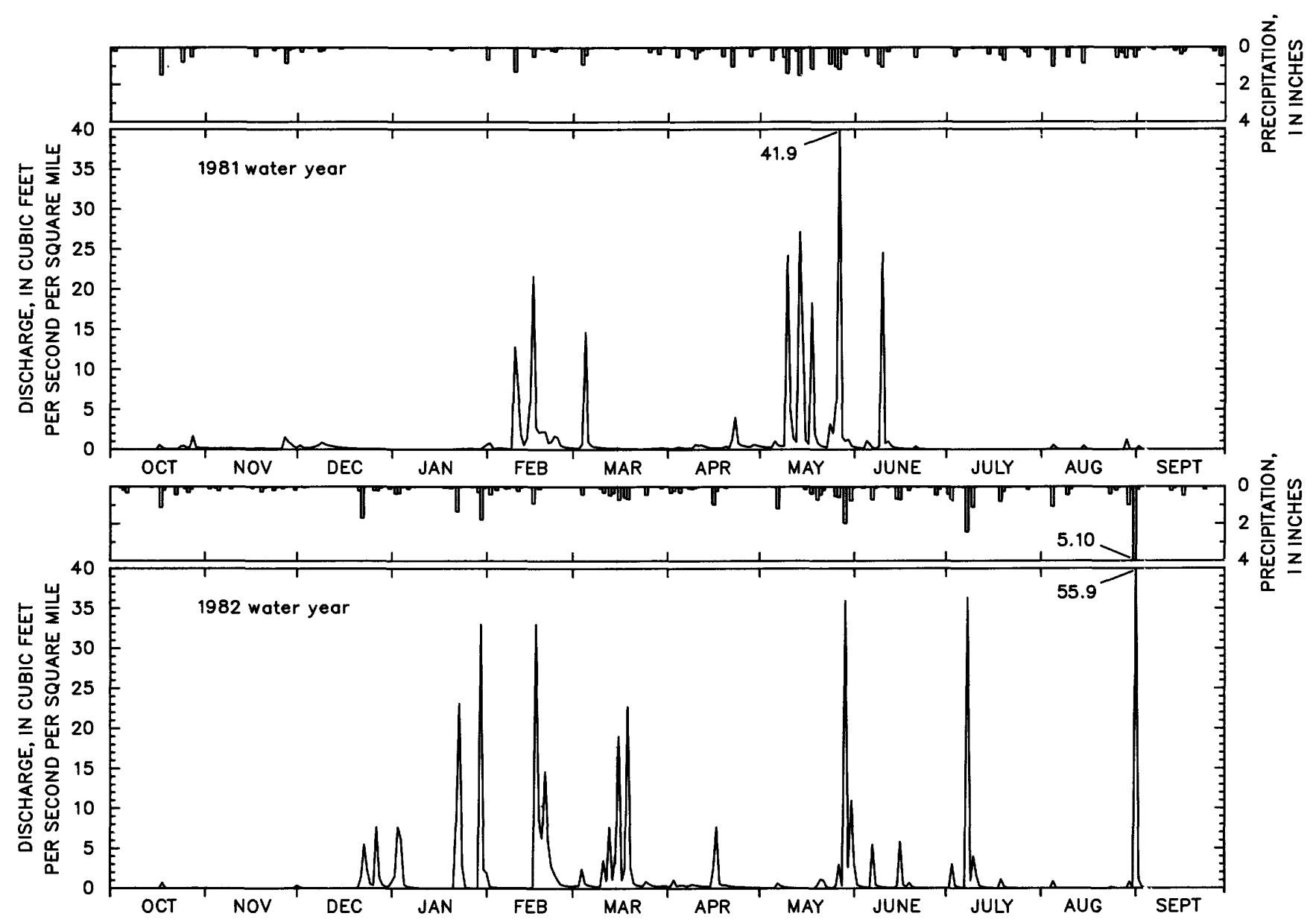

Figure 6B. Daily mean discharge and daily precipitation at Hooker Creek, 1981 and 1982 water years.

tinuous and less variable than discharge at the other watersheds. Discharge at the other watersheds was intermittent. Periods of no flow occurred about 2 percent of the time at Big Slough, about 24 percent of the time at Hooker Creek, about 76 percent of the time at Honey Creek tributary, and about 21 percent of the time at Sulphur Creek tributary. The large percentage of no-flow days at Honey Creek tributary is characteristic of ephemeral streams that flow only during and immediately after storms or snowmelt. Hooker Creek was dry more frequently than Big Slough, probably because of transpiration from the greater amount of riparian forest along Hooker Creek.

Two other groups of curves in figure 7 also are apparent on the basis of discharge that is equaled or exceeded 1 percent of the time. Daily mean discharge equaled or exceeded 1 percent of the time at Big Slough and Hooker Creek was 22.4 and $28.2\left(\mathrm{ft}^{3} / \mathrm{s}\right) / \mathrm{mi}^{2}$, respectively, whereas the 1-percent discharge at the other watersheds ranged from 9.80 to $13.1\left(\mathrm{ft}^{3} / \mathrm{s}\right) / \mathrm{mi}^{2}$. Median discharge (discharge equaled or exceeded 50 percent of the time) at Pond Creek and Big Branch tributary was 2.4 to almost 13 times greater than the median discharge at Big Slough,
Hooker Creek, and Sulphur Creek tributar'. Median discharge at Honey Creek tributary was $0.00\left(\mathrm{ft}^{3} / \mathrm{s}\right) / \mathrm{mi}^{2}$.

\section{Extremes}

The five maximum and minimum daily mean discharges shown in table 2 at each watershed for the 1981 and 1982 water years illustrate the extreme flow characteristics of the watersheds. The five highest daily mean discharges were usually greater at Big Slough and Hocker Creek than at the other watersheds. The five highes daily mean discharges at Honey Creek tributary, Sulphur Creek tributary, Pond Creek, and Big Branch tributary are similar in magnitude. Nearly all of the high flows in the 1981 water year occurred during the heavy frontal storms of May and June. Precipitation on frozen soil and (or) snowmelt caused most of the high flows to occur during January and February in the 1982 water year (figs. 5, 6, and table 2). Intense thunderstorms during July and September caused some of the largest high flows during the 1982 wate- year, but few high flows were observed during the summer of the 1981 water year (fig. 6 and table 2).

Honey Creek tributary had the greatest number of 


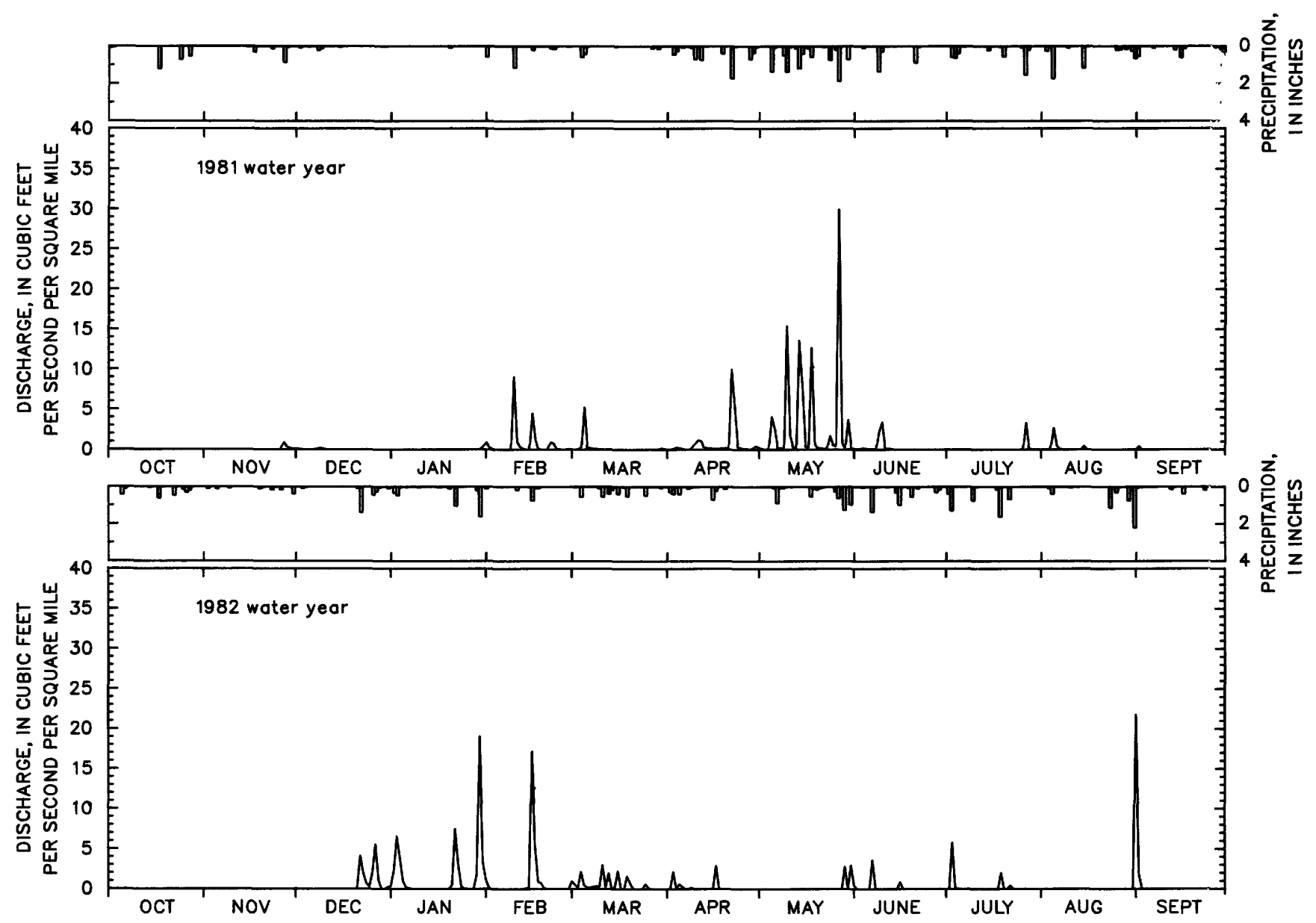

Figure 6C. Daily mean discharge and daily precipitation at unnamed tributary to Honey Creek, 1981 and $19^{\wedge} ?$ water years.

no-flow days, followed by Hooker Creek, Sulphur Creek tributary, and Big Slough (table 2). Low flows for Pond Creek and Big Branch tributary were similar during both water years. Low flows generally occurred during late summer and fall and occasionally during winter.

\section{Runoff}

\section{Annual Runoff and Water Loss}

Annual runoff was greatest at Big Branch tributary and least at Honey Creek tributary for both water years (table 3). The relative magnitudes and patterns of annual runoff are the same as the magnitudes and patterns of annual mean discharge (table 1) because discharge and runoff are the same quantities expressed in different units of measure.

Annual runoff coefficients attempt to account for the effect of precipitation on runoff. The annual runoff coefficient is the annual runoff expressed as a percentage of the annual precipitation. Incorporating differences in precipitation in the amount of runoff did not appreciably change results based on runoff alone. The unreclaimed watersheds had the greatest runoff, the reclaimed watersheds had the least runoff, and runoff at the agricultural watersheds was intermediate. An exception to this pattern was d ring the 1982 water year when Big Slough had a larger runoff coefficient than Pond Creek (table 3). Annual ruroff coefficients averaged 55.5 percent at Big Branch tribut ${ }^{\circ}$ ry, 39.5 percent at Pond Creek, 35.5 percent at Big Slough, 35.3 percent at Hooker Creek, 29.2 percent at Sulph'r Creek tributary, and 16.6 percent at Honey Creek tribut'ry.

Annual water loss is the difference between annual precipitation and annual runoff. The term "water loss" developed from the concept of runoff as the residual precipitation after losses from evapotranspiration. Water loss can be used to estimate evapotranspiration in large watersheds where surface- and ground-water divites coincide and the flow of ground water beneath the gage is negligible (Hoyt and others, 1936; Williams and others, 1940).

In this study, water loss is used to examine the combined effects of evapotranspiration and ground-water 


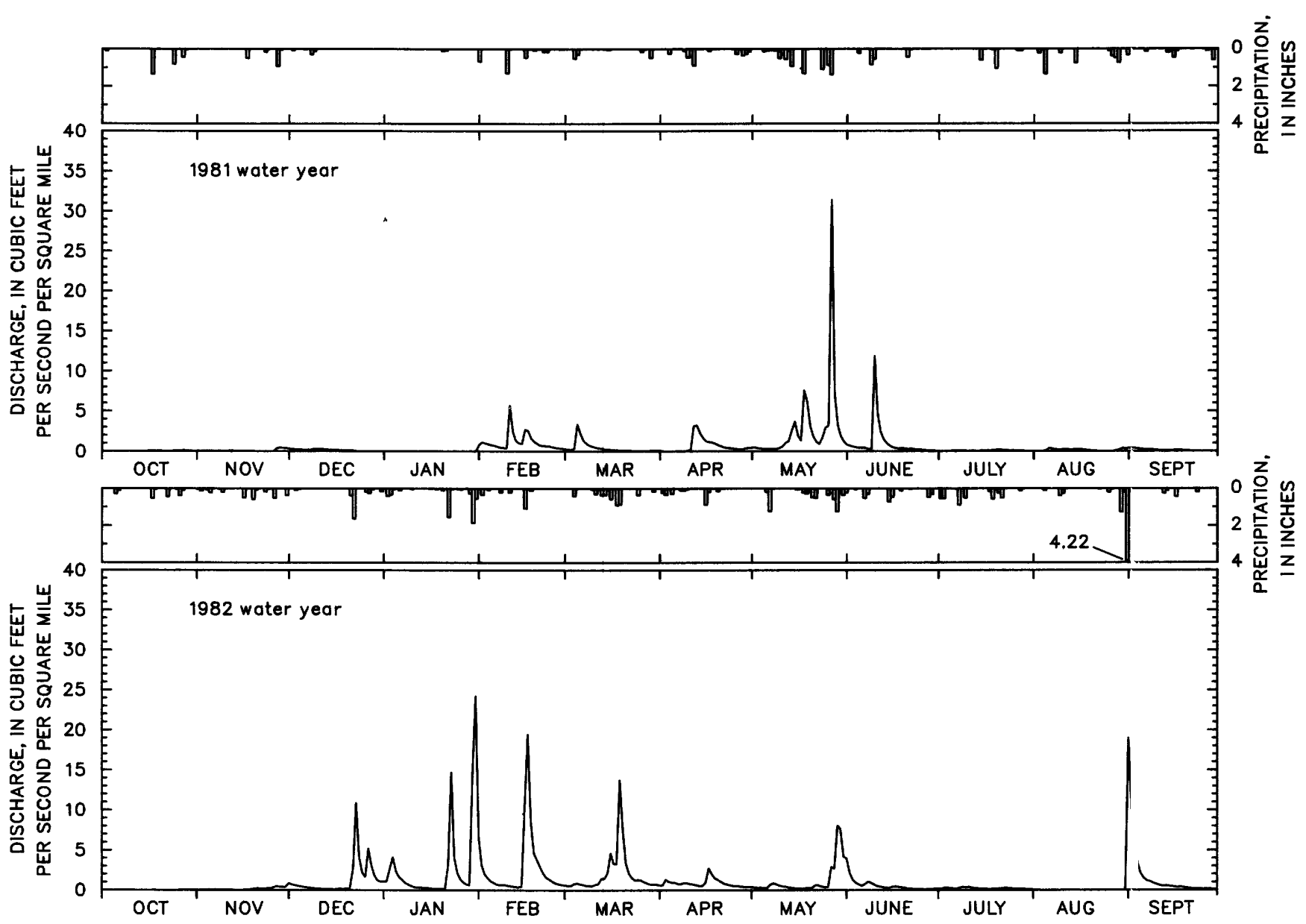

Figure 6D. Daily mean discharge and daily precipitation at unnamed tributary to Sulphur Creek, 1981 and 1982 water years.

movement into or out of the watershed. Without accurate information on ground-water divides and flow paths, estimates of evapotranspiration based on water loss are unreliable. For example, if surface- and ground-water divides coincide, but a substantial part of the precipitation that percolates to the water table flows out of the watershed beneath the gage (does not contribute to streamflow measured at the gage), then evapotranspiration is overestimated. Another source of uncertainty occurs when surface- and ground-water divides do not coincide. For example, if the ground-water divides enclose an area substantially larger than the surface-water divides and all of the ground water contributes to streamflow measured at the gage, then evapotranspiration is underestimated.

Annual water loss ranged from 15.1 to $31.0 \mathrm{in}$. during water years 1981 and 1982 (table 3). Water loss during both years was least at Big Branch tributary and was greatest at Honey Creek tributary. No relation is evident between water loss and precipitation, runoff, or water year. Inspection of the average annual water loss shows that Big Slough, Hooker Creek, Sulphur Creek tributary, and Pond
Creek have similar average water losses ( $\mathrm{t}$-ble 3 ). Honey Creek tributary has approximately 4.25 in. more water loss than these watersheds, and Big Branch tributary has approximately $10 \mathrm{in}$. less water loss than the watersheds. Differences in evapotranspiration alone probably do not account for the large differences in water lo:s in the Honey Creek and Big Branch tributary watersheds. The high water loss at Honey Creek tributary is likely caused by groundwater flow beneath the gage. Water infiltrat $>s$ into the soil, percolates to the water table, and is discharged downstream of the gaging station. The low water loss at Big Branch tributary probably is caused by increased streamflow due to the inflow of ground water from areas adjacent to the watershed.

\section{Monthly Runoff}

Major differences in monthly precipitation and runoff are evident between the 1981 and 1982 water years (fig. 8). Precipitation during the 1981 water year was greatest during May and least during January and December. Precipitation was much more evenly distributed during the 1982 water 


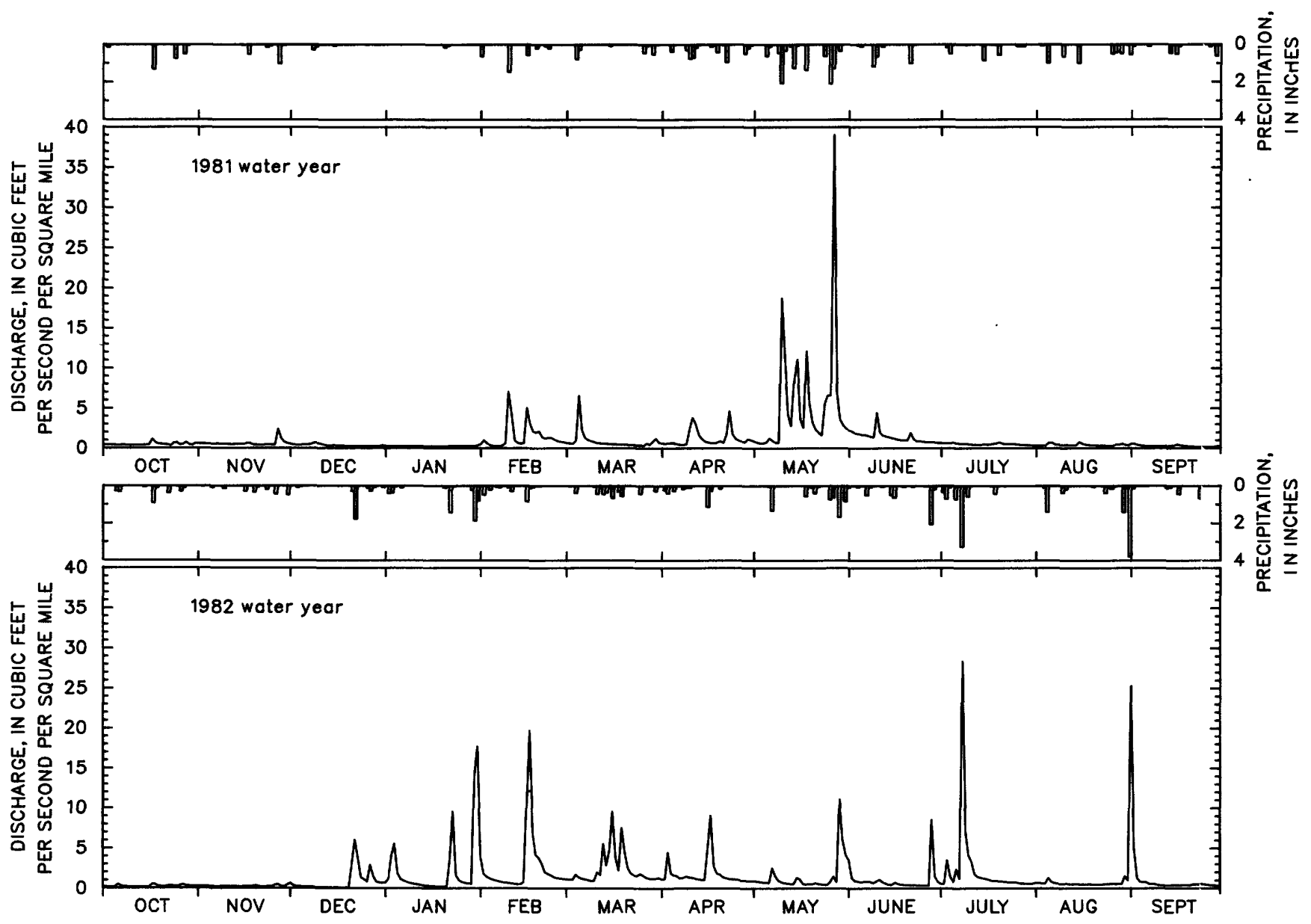

Figure 6E. Daily mean discharge and daily precipitation at Pond Creek, 1981 and 1982 water years.

year. The major part of the annual runoff for the 1981 water year was during May, and much smaller amounts occurred during the other months. Runoff for the 1982 water year was more evenly distributed, and the greatest amounts were caused by snowmelt in January and February or by rainfall in March. The large amounts of runoff during July and September 1982 were caused by thunderstorms (fig. 6).

As with annual runoff, differences in monthly runoff are apparent among watersheds. During May of the 1981 water year, runoff was 2 to 3 in. less at Honey Creek tributary and Sulphur Creek tributary than at the other watersheds (fig. 8). However, the most noticeable differences in monthly runoff were during the low-flow periods from October 1980 through January 1981 and from July 1981 through November 1981. Relatively large amounts of runoff were recorded during these months at Big Branch tributary and Pond Creek, whereas much smaller amounts or no runoff were recorded at the other watersheds.

Runoff exceeded precipitation at Big Branch tributary during December, January, and June of the 1981 water year and during February and April of the 1982 water year. The relation between precipitation and runoff for these months may have been caused by delayed base flow that originated within the watershed but probably is additional evidence that ground water enters Big Branch tributary from outside of the watershed. Snowmelt during February 19£2 caused runoff to exceed precipitation at all watersheds except Honey Creek tributary (fig. 8).

\section{Peak Discharge}

The dates of the five largest instantane ous peak discharges (table 4) are similar to those of the five largest daily mean discharges (table 2). The dates are similar, but not the same because table 4 shows the maximum discharge per 5-minute interval, whereas table 2 shows the maximum discharge per day. High-intensity, shor'-duration storms characteristic of thunderstorms that typically occur during summer are as likely to cause peak flow rates as low-intensity, long-duration storms characteristic of frontal storms that typically occur during winter and sprin $\pi$. Five of nine peak discharges greater than $150\left(\mathrm{ft}^{3} / \mathrm{s}\right) / \mathrm{ni}^{2}$ were caused by thunderstorms (table 4). 


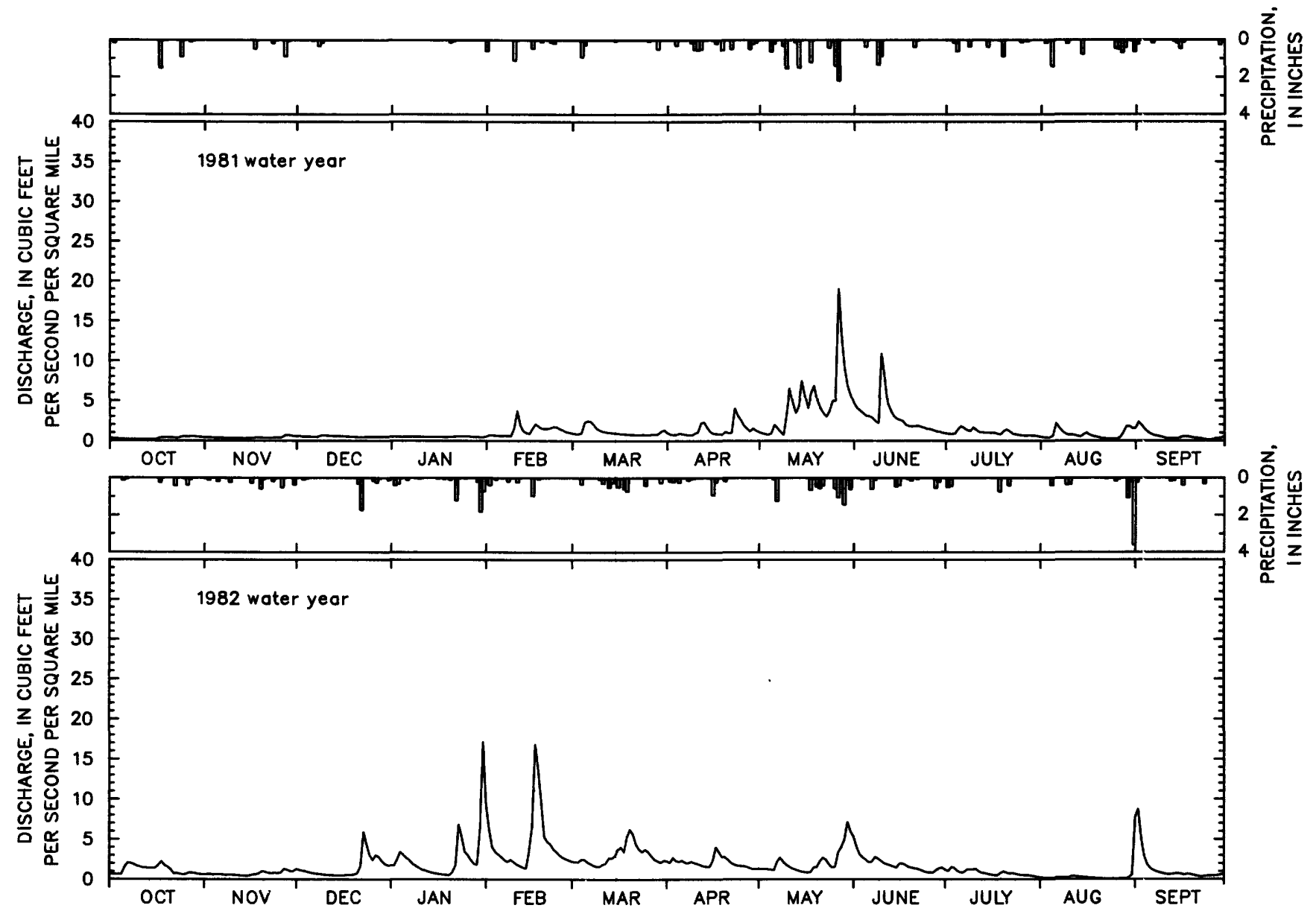

Figure $6 F$. Daily mean discharge and daily precipitation at unnamed tributary to Big Branch, 1981 and 1982 water years.

The majority of peak discharges during the 1981 water year were caused by frequent periods of rainfall on saturated soils during May. The majority of peak discharges during the 1982 water year were caused by thunderstorms in July and September or by rainfall on frozen soils and (or) snowmelt during January and February.

The smallest peak discharges were at Big Branch tributary and Sulphur Creek tributary, probably because of the final-cut lakes at the mouths of these watersheds. These lakes reduce peak discharge by storing and slowly releasing surface runoff. The greatest peak discharges were at Hooker Creek, at Big Slough, and to a lesser degree, especially during the 1982 water year, at Honey Creek tributary (table 4).

Peak discharges for September 1, 1982, at Pond Creek and for February 17, 1982, at Big Branch tributary are unknown. Record was lost because of a recorder malfunction on September 1, 1982, and a frozen stilling well on February 17, 1982. The day of the peak and the relative magnitude of the peak were estimated by comparing hydrographs with intensities and volumes of precipitation.

\section{Precipitation-Runoff Relations}

\section{Storm Hydrographs}

Eight storms were selected to study the response of runoff to precipitation and to compare responses among the study watersheds. Both high-intensity, short-duration thunderstorms and low-intensity, long-duration frontal storms were studied. Storms were selected for stuc'v by using the following criteria: (1) Instantaneous (5-minu ${ }^{+}$interval, 288 values per day) discharge and precipitation data were available for at least five of the six watersheds. (2) Storms having large volumes of precipitation were most suitable for study. (3) Temporal distribution and volume of precipitation during the storm were similar among v'atersheds. On the basis of the above criteria, four thunderstorms and four frontal storms were selected. The selected thunderstorms occurred on May 24, 1981 (fig. $9 A$ and $t^{t}$ ble $5 A$ ); June 9-10, 1981 (fig. $9 B$ and table 5B); May 29, 1982 (fig. 9C and table 5C); and September 1, 1982 (fig. 9D and table $5 D$ ). The selected frontal storms occurred on May 26-27, 1981 (fig. $9 E$ and table 5E); December 21-22, 1981 (fig. 

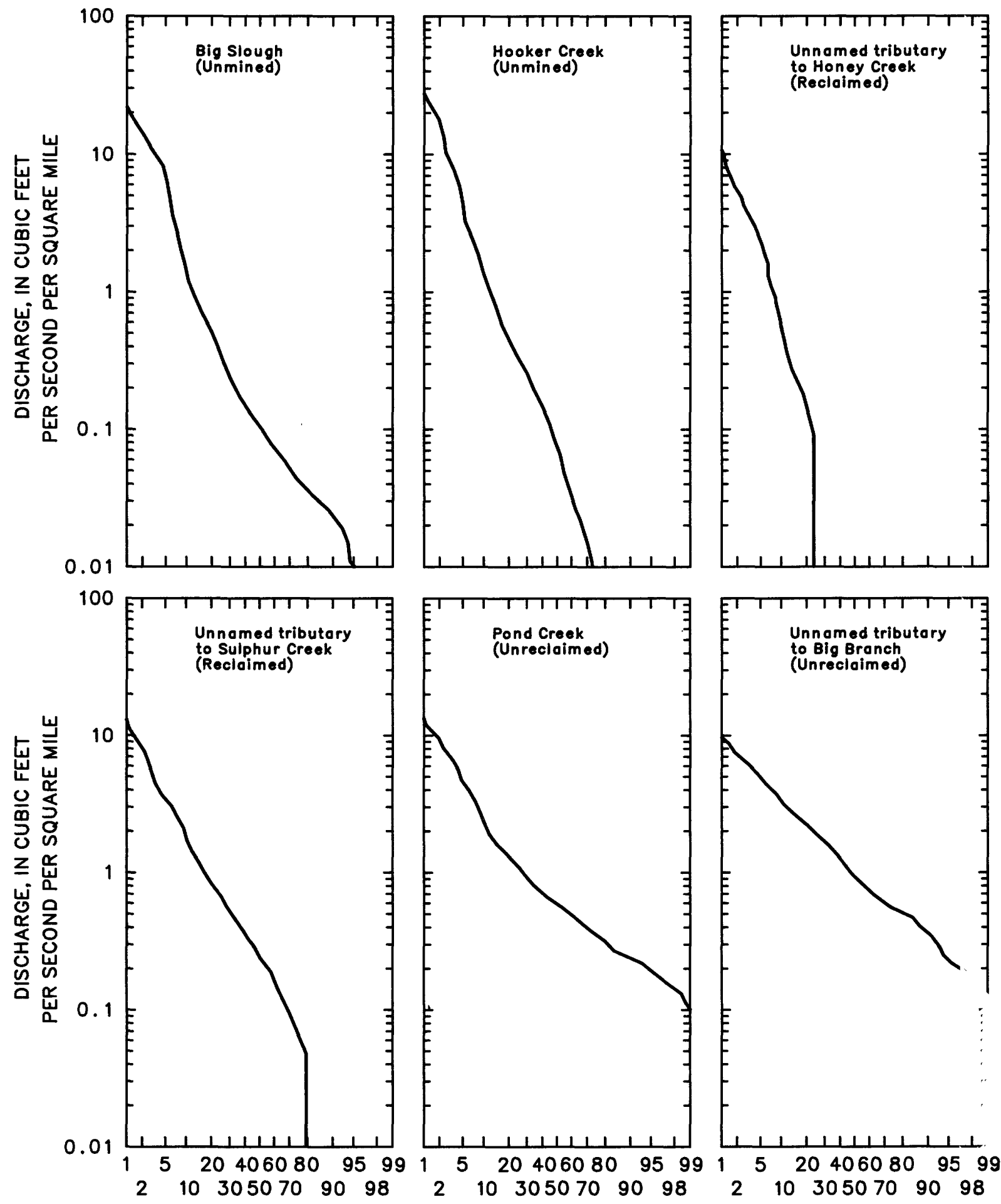

PERCENTAGE OF TIME DAILY MEAN DISCHARGE WAS EQUALED OR EXCEEDED

Figure 7. Duration curves of daily mean discharge at six study watersheds, 1981 and 1982 water years.

and April 16-17, 1982 (fig. $9 H$ and table $5 H$ ). To ease comparison, figure 9 and table 5 are grouped together following the References Cited section.

The greatest amount of precipitation for the eight storms selected for study occurred on September 1,
1982 , and ranged from 2.26 to 5.26 in. (table $5 D$ ). The least amount of precipitation for the eight storms oc?urred on May 24, 1981, and ranged from 0.43 to 1.10 in. (table $5 A$ ). The greatest maximum precipitation intensity occurred during the thunderstorm of September 1, 1982, and ranged 

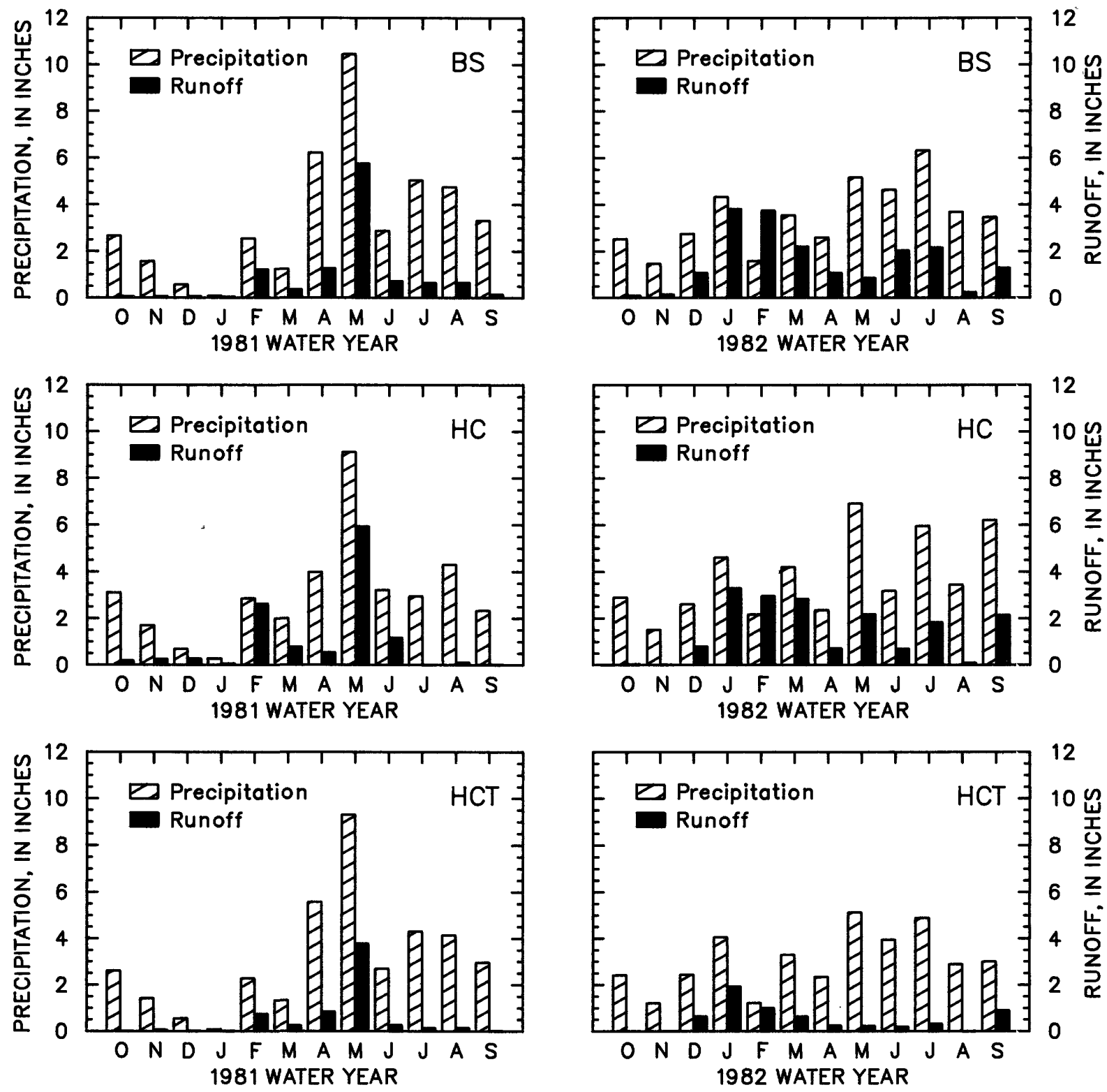

Figure 8. Monthly precipitation and runoff at six study watersheds, 1981 and 1982 water years. BS, Big̨ Slough (Unmined); HC, Hooker Creek (Unmined); HCT, unnamed tributary to Honey Creek (Reclaimed); SCT, unnamed tributary to Sulphur Creek (Reclaimed); PC, Pond Creek (Unreclaimed); BBT, unnamed trik'ıtary to Big Branch (Unreclaimed).

from 0.28 to 0.52 in. during 5 minutes, from 0.52 to 0.75 in. during 10 minutes, and from 1.21 to $2.84 \mathrm{in}$. during 1 hour (table $5 D$ ). The smallest maximum precipitation intensity for the eight storms occurred during the frontal storm of January 22, 1982, and ranged from 0.07 to 0.09 in. during 5 minutes, from 0.09 to $0.14 \mathrm{in}$. during 10 minutes, and from 0.23 to 0.35 in. during 1 hour (table $5 G$ ).

Methods of hydrograph separation typically are used to determine the source components of storm runoff (surface runoff, interflow, or ground-water flow). A quantitative determination of the source components of storm runoff was not attempted because of the confoundir $r$ effect of the final-cut lakes in the Sulphur Creek tributary, Pond Creek, and Big Branch tributary watersheds. Hydrograph separation was used in this study to determine the trtal volume of storm runoff, regardless of source. Volumes of storm runoff were calculated by the following method. Discharge (base flow) was determined immediately before the initial rise of the hydrograph. When discharge returned to base flow, storm runoff was assumed to have ceased. Tre total volume of runoff during the storm was measured. The volume of storm runoff was calculated as the total volume of runoff minus the volume of base flow. 

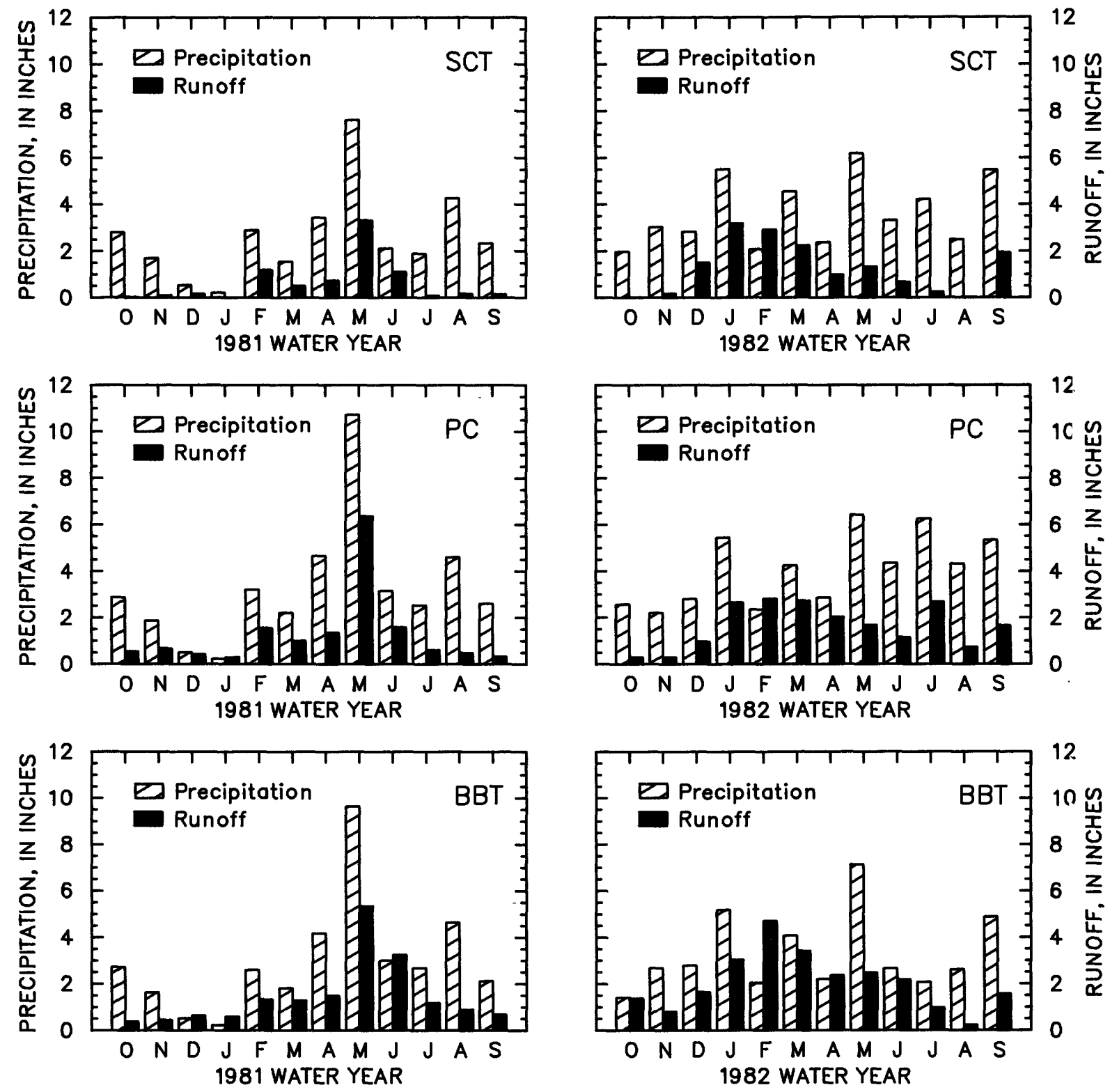

Figure 8. Continued.

If discharge failed to return to base flow before another storm occurred, the recession curve and the corresponding volume of runoff were estimated. For all cases where estimates were required, the estimated volume of storm runoff was less than 5 percent of the total volume of storm runoff. The time from the initial rise of the hydrograph to the instantaneous peak discharge (the first occurrence of the maximum discharge if more than one) also was determined for each storm hydrograph.

\section{Precipitation-Runoff Volumes}

The frontal storms of January 22, 1982 (table $5 G$ ), and May 26-27, 1981 (table 5E), generated much greater proportions of runoff (volume of runoff divided b:" volume of precipitation, or the runoff coefficient) than the other six storms. Average runoff from all six watersheds was approximately 65 and 57 percent of precipitation for these two storms, but average runoff ranged only from 27 to 36 percent of precipitation for the other six storms (table 5). Runoff for the storm of January 22, 1982, occurre 1 after an extended period of freezing temperatures, when 1.07 to 1.59 in. of rain fell on a cover of snow having about 0.10 to 0.31 in. of water equivalent. Snowmelt and reduced infiltration because of frozen soil helped cause 34.0 to 95.5 percent of the rainfall to run off (table $5 G$ ). Large proportions of runoff resulted from the storm of May 26-27, 1981, when 2.08 to 3.62 in. of precipitation fell on wet soil. 
Table 2. Extremes of daily mean discharge at six study watersheds $\left[\left(\mathrm{ft}^{3} / \mathrm{s}\right) / \mathrm{mi}^{2}\right]$, cubic feet per second per square mile]

\begin{tabular}{|c|c|c|c|c|c|c|c|c|}
\hline \multirow[b]{3}{*}{ Watershed } & \multicolumn{4}{|c|}{ Maximum daily mean discharge } & \multicolumn{4}{|c|}{ Minimum daily mean discharge } \\
\hline & \multicolumn{2}{|c|}{1981 water year } & \multicolumn{2}{|c|}{1982 water year } & \multicolumn{2}{|c|}{1981 water year } & \multicolumn{2}{|c|}{1982 water year } \\
\hline & $\begin{array}{l}\text { Discharge } \\
\left(\mathrm{ft}^{3} / \mathrm{s}\right) / \mathrm{mi}^{2}\end{array}$ & Date & $\begin{array}{l}\text { Discharge } \\
\left(\mathrm{ft}^{3} / \mathrm{s}\right) / \mathrm{mi}^{2}\end{array}$ & Date & $\begin{array}{l}\text { Discharge } \\
\left(\mathrm{ft}^{3} / \mathrm{s}\right) / \mathrm{mi}^{2}\end{array}$ & Date & $\begin{array}{l}\text { Discharge } \\
\left(\mathrm{ft}^{3} / \mathrm{s}\right) / \mathrm{mi}^{2}\end{array}$ & Date \\
\hline \multicolumn{9}{|l|}{$\begin{array}{l}\text { Big Slough } \\
\text { (Unmined) }\end{array}$} \\
\hline (Unmined) & 31.9 & May 27 & 38.1 & Jan. 30 & 0.000 & 14 days & 0.000 & Oct. 1 \\
\hline & 28.5 & May 10 & 33.0 & Sept. 1 & & & .000 & Oct. 2 \\
\hline & 21.1 & May 18 & 31.1 & Feb. 17 & & & .000 & Oct. 3 \\
\hline & 18.1 & May 14 & 27.8 & June 7 & & & .007 & Oct. 4 \\
\hline & 16.3 & $\begin{array}{l}\text { May } 30 \text { and } \\
\text { July } 27\end{array}$ & 23.3 & July 19 & & & .007 & Oct. 12 \\
\hline \multicolumn{3}{|l|}{$\begin{array}{l}\text { Hooker Creek } \\
\text { (Unmined) }\end{array}$} & 55.9 & Sept. 1 & & 91 days & & 81 days \\
\hline & 27.2 & May 14 & 36.4 & July 8 & & & & \\
\hline & 24.6 & June 10 & 36.0 & May 29 & & & & \\
\hline & 24.3 & May 10 & 33.1 & Jan. 30 & & & & \\
\hline & 21.7 & Feb. 16 & 33.1 & Feb. 17 & & & & \\
\hline \multicolumn{9}{|l|}{$\begin{array}{l}\text { Unnamed tributary to } \\
\text { Honey Creek }\end{array}$} \\
\hline & 30.0 & May 27 & 21.8 & Sept. 1 & .000 & 259 days & .000 & 298 days \\
\hline & 15.5 & May 10 & 19.1 & Jan. 30 & & & & \\
\hline & 13.6 & May 14 & 17.3 & Feb. 16 & & & & \\
\hline & 12.7 & May 18 & 7.55 & Jan. 22 & & & & \\
\hline & 10.0 & Apr. 22 & 6.64 & Jan. 3 & & & & \\
\hline \multicolumn{9}{|l|}{$\begin{array}{l}\text { Unnamed tributary to } \\
\text { Sulphur Creek }\end{array}$} \\
\hline (Reclaimed) ...... & 31.4 & May 27 & 24.3 & Jan. 31 & .000 & 98 days & .000 & 53 days \\
\hline & 11.9 & June 10 & 19.5 & Feb. 17 & & & & \\
\hline & 7.62 & May 18 & 19.0 & Sept. 1 & & & & \\
\hline & 7.14 & May 28 & 14.8 & Jan. 23 & & & & \\
\hline & 6.19 & May 19 & 14.8 & Jan. 30 & & & & \\
\hline \multicolumn{9}{|l|}{ Pond Creek } \\
\hline (Unreclaimed) $\ldots \ldots \ldots \ldots$ & 39.1 & May 27 & 28.4 & July 8 & .147 & Sept. 24 & .076 & Dec. $17-20$ \\
\hline & 18.8 & May 10 & 25.4 & Sept. 1 & .152 & Sept. 25 & .081 & Dec. 16 \\
\hline & 12.2 & May 18 & 19.8 & Feb. 17 & .157 & Sept. 23 & & \\
\hline & 11.2 & May 11 & 17.8 & Jan. 31 & .157 & Sept. 28 & & \\
\hline & 11.2 & May 15 & 14.2 & Jan. 30 & .162 & Sept. 26 & & \\
\hline \multirow{2}{*}{\multicolumn{9}{|c|}{$\begin{array}{l}\text { Unnamed tributary to } \\
\text { Big Branch }\end{array}$}} \\
\hline & & & & & & & & \\
\hline & 13.1 & May 28 & 16.9 & Feb. 17 & .156 & Sept. 24 & & \\
\hline & 10.9 & June 10 & 13.8 & Feb. 18 & .156 & Sept. 26 & & \\
\hline & 9.06 & May 29 & 9.69 & Feb. 19 & .188 & Oct. 6-16 & & \\
\hline & 8.13 & June 11 & 9.38 & Feb. 1 & & & & \\
\hline
\end{tabular}

Table 3. Annual runoff and annual water loss at six study watersheds

[in., inch]

\begin{tabular}{|c|c|c|c|c|c|c|c|c|c|c|c|c|}
\hline \multirow[b]{2}{*}{ Watershed } & \multicolumn{3}{|c|}{ Annual runoff (in.) } & \multicolumn{3}{|c|}{ Annual runoff coefficient ${ }^{1}$ (percent) } & \multicolumn{3}{|c|}{ Annual water $\operatorname{loss}^{2}$ (in.) } & \multicolumn{3}{|c|}{ Annual precipitation (in.) } \\
\hline & $\begin{array}{l}1981 \\
\text { water } \\
\text { year }\end{array}$ & $\begin{array}{l}1982 \\
\text { water } \\
\text { year }\end{array}$ & Average & $\begin{array}{c}1981 \\
\text { water } \\
\text { year }\end{array}$ & $\begin{array}{l}1982 \\
\text { water } \\
\text { year }\end{array}$ & Average & $\begin{array}{l}1981 \\
\text { water } \\
\text { year }\end{array}$ & $\begin{array}{l}1982 \\
\text { water } \\
\text { year }\end{array}$ & Average & $\begin{array}{l}1981 \\
\text { water } \\
\text { year }\end{array}$ & $\begin{array}{l}1982 \\
\text { vater } \\
\text { year }\end{array}$ & Average \\
\hline Hooker Creek (Unmined) . . & 11.9 & 17.5 & 14.70 & 32.6 & 38.0 & 35.30 & 24.6 & 28.6 & 26.60 & 36.5 & 46.1 & 41.30 \\
\hline $\begin{array}{l}\text { Unnamed tributary to Honey } \\
\text { Creek (Reclaimed) } \ldots \ldots \ldots \\
\text { Unnamed tributary to Sulphur }\end{array}$ & 6.3 & 6.0 & 6.15 & 16.9 & 16.3 & 16.60 & 31.0 & 30.8 & 30.90 & 37.3 & 36.8 & 37.05 \\
\hline $\begin{array}{l}\text { Unnamed tributary to Big Branch } \\
\text { (Unreclaimed) } \ldots \ldots \ldots \ldots \ldots\end{array}$ & 17.5 & 24.7 & 21.10 & 48.9 & 62.1 & 55.50 & 18.3 & 15.1 & 16.70 & 35.8 & 39.8 & 37.80 \\
\hline
\end{tabular}

${ }^{1}$ Annual runoff coefficient is annual runoff divided by annual precipitation multiplied by 100 percent.

${ }^{2}$ Annual water loss is annual precipitation minus annual runoff. 
Table 4. Instantaneous peak discharge at six study watersheds

$\left[\left(\mathrm{ft}^{3} / \mathrm{s}\right) / \mathrm{mi}^{2}\right.$, cubic feet per second per square mile]

\begin{tabular}{|c|c|c|c|c|c|c|}
\hline \multirow[b]{2}{*}{ Watershed } & \multicolumn{3}{|c|}{1981 water year } & \multicolumn{3}{|c|}{1982 water year } \\
\hline & $\begin{array}{l}\text { Peak discharge } \\
\left(\mathrm{ft}^{3} / \mathrm{s}\right) / \mathrm{mi}^{2}\end{array}$ & Date & Time & $\begin{array}{l}\text { Peak discharge } \\
\left(\mathrm{ft}^{3} / \mathrm{s}\right) / \mathrm{mi}^{2}\end{array}$ & Date & Time \\
\hline Big Slough & & & & & & \\
\hline (Unmined) $\ldots \ldots \ldots \ldots \ldots$ & $\begin{array}{r}155.6 \\
123.7 \\
111.5 \\
111.1 \\
93.7\end{array}$ & $\begin{array}{l}\text { July } 27 \\
\text { May } 18 \\
\text { May } 30 \\
\text { May } 27 \\
\text { Aug. } 5\end{array}$ & $\begin{array}{l}1735 \\
0945 \\
0815 \\
0430 \\
1430\end{array}$ & $\begin{array}{l}155.9 \\
153.3 \\
151.5 \\
127.8 \\
101.9\end{array}$ & $\begin{array}{l}\text { Sept. } 1 \\
\text { June } 7 \\
\text { July } 3 \\
\text { July } 19 \\
\text { Jan. } 23\end{array}$ & $\begin{array}{l}0615 \\
1155 \\
0530 \\
0515 \\
0055\end{array}$ \\
\hline Hooker Creek & & & & & & \\
\hline (Unmined) $\ldots \ldots \ldots \ldots \ldots$ & $\begin{array}{r}155.9 \\
17.6 \\
94.9 \\
84.9 \\
68.0\end{array}$ & $\begin{array}{l}\text { May } 27 \\
\text { June } 10 \\
\text { May } 18 \\
\text { Feb. } 10 \\
\text { Feb. } 16\end{array}$ & $\begin{array}{l}0505 \\
0335 \\
0955 \\
1905 \\
1035\end{array}$ & $\begin{array}{l}251.1 \\
212.9 \\
182.4 \\
130.9 \\
102.2\end{array}$ & $\begin{array}{l}\text { Sept. } 1 \\
\text { July } 8 \\
\text { May } 29 \\
\text { Jan. } 23 \\
\text { Mar. } 16\end{array}$ & $\begin{array}{l}0655 \\
0940 \\
1645 \\
0140 \\
0540\end{array}$ \\
\hline $\begin{array}{l}\text { Unnamed tributary to Honey } \\
\text { Creek }\end{array}$ & & & & & & \\
\hline (Reclaimed) $\ldots \ldots \ldots \ldots \ldots$ & $\begin{array}{r}163.6 \\
109.1 \\
72.7 \\
67.3 \\
54.5\end{array}$ & $\begin{array}{l}\text { May } 27 \\
\text { May } 18 \\
\text { Apr. } 22 \\
\text { May } 14 \\
\text { June } 9\end{array}$ & $\begin{array}{l}0245 \\
0855 \\
2135 \\
2020 \\
2325\end{array}$ & $\begin{array}{l}88.2 \\
80.0 \\
68.2 \\
67.3 \\
42.7\end{array}$ & $\begin{array}{l}\text { Sept. } 1 \\
\text { Jan. } 22 \\
\text { July } 3 \\
\text { Jan. } 30 \\
\text { Dec. } 27\end{array}$ & $\begin{array}{l}0620 \\
2400 \\
0520 \\
1400 \\
0045\end{array}$ \\
\hline $\begin{array}{l}\text { Unnamed tributary to Sulphur } \\
\text { Creek }\end{array}$ & & & & & & \\
\hline (Reclaimed) $\ldots \ldots \ldots \ldots \ldots$ & $\begin{array}{c}57.1 \\
22.9 \\
13.8 \\
10.0 \\
4.05\end{array}$ & $\begin{array}{l}\text { May } 27 \\
\text { June } 10 \\
\text { May } 18 \\
\text { Feb. } 10 \\
\text { Feb. } 16\end{array}$ & $\begin{array}{l}0130 \\
0550 \\
1715 \\
2140 \\
1355\end{array}$ & $\begin{array}{l}38.6 \\
33.8 \\
31.4 \\
27.1 \\
19.0\end{array}$ & $\begin{array}{l}\text { Sept. } 1 \\
\text { Jan. } 31 \\
\text { Feb. } 16 \\
\text { Jan. } 23 \\
\text { Mar. } 19\end{array}$ & $\begin{array}{l}1210 \\
0740 \\
2030 \\
0050 \\
1150\end{array}$ \\
\hline $\begin{array}{l}\text { Pond Creek } \\
\text { (Unreclaimed) } \ldots \ldots \ldots \ldots \ldots\end{array}$ & $\begin{array}{l}85.8 \\
57.9 \\
32.0 \\
25.9 \\
20.3\end{array}$ & $\begin{array}{l}\text { May } 27 \\
\text { May } 10 \\
\text { May } 18 \\
\text { May } 15 \\
\text { Feb. } 10\end{array}$ & $\begin{array}{l}0215 \\
1620 \\
1050 \\
0035 \\
1830\end{array}$ & $\begin{array}{l}110.7 \\
\left(^{1}\right) \\
32.5 \\
32.5 \\
28.4\end{array}$ & $\begin{array}{l}\text { July } 8 \\
\text { Sept. } 1 \\
\text { Jan. } 31 \\
\text { Feb. } 16 \\
\text { Jan. } 23\end{array}$ & $\begin{array}{r}0950 \\
\left(\begin{array}{l}1 \\
)\end{array}\right. \\
0820 \\
2100 \\
0115\end{array}$ \\
\hline $\begin{array}{l}\text { Unnamed tributary to Big Branch } \\
\text { (Unreclaimed) } \ldots \ldots \ldots \ldots \ldots \ldots\end{array}$ & $\begin{array}{c}.23 .8 \\
14.7 \\
7.81 \\
7.81 \\
6.88\end{array}$ & $\begin{array}{l}\text { May } 27 \\
\text { June } 10 \\
\text { May } 15 \\
\text { May } 18 \\
\text { May } 10\end{array}$ & $\begin{array}{l}1015 \\
1000 \\
0630 \\
1800 \\
2230\end{array}$ & $\begin{array}{l}19.7 \\
\left(^{1}\right) \\
11.6 \\
7.81 \\
7.50\end{array}$ & $\begin{array}{l}\text { Jan. } 31 \\
\text { Feb. } 17 \\
\text { Sept. } 1 \\
\text { May } 29 \\
\text { Jan. } 23\end{array}$ & $\begin{array}{r}1015 \\
\left(\begin{array}{l}1 \\
)\end{array}\right. \\
1345 \\
2230 \\
0545\end{array}$ \\
\hline
\end{tabular}

${ }^{1}$ Date and relative magnitude of peak flow rate were estimated.

Runoff ranged from 35.1 to 81.7 percent of precipitation (table $5 E$ ). The largest runoff coefficient (95.5 percent) was at Hooker Creek during the storm of January 22, 1982 (table $5 G)$. The smallest runoff coefficient $(8.3$ percent) was at Pond Creek during the storm of June 9-10, 1981 (table 5B).

No pattern in runoff coefficients was apparent among watersheds. Relative rankings of watersheds, based on the runoff coefficients, varied widely from storm to storm and failed to show consistent differences among watersheds. The most consistent patterns were at Hooker Creek and Honey Creek tributary for three of the eight storms; Hooker Creek had the greatest runoff coefficient for three storms, and Honey Creek tributary had the smallest runoff coefficient for three storms. However, the largest runoff coefficient for at least one of the eight storms was at Big Slough, Hooker Creek, Sulphur Creek tributary, and Pond Creek. The smallest runoff coefficient for at least one of the eight storms was at Hooker Creek, Honey Creek tributary, Pond Creek, and Big Branch tributary.
Variations in the relative rankings of watersheds by runoff coefficients for the eight storms cannot be explained by maximum precipitation intensity, precipitation volume, or the amount of precipitation in the previous 3 or 7 days (table 5). Lack of a relation between storm runoff coefficients and precipitation volume, intensity, antecedent moisture, or watershed indicates that the proportion of precipitation that contributes to streamflow cannot be determined solely from land use, watershed morphology, precipitation volume, maximum precipitation intensity, and (or) antecedent moisture as measured in this study.

Lack of a consistent pattern in runoff co ${ }^{\circ}$ fficients among the six watersheds indicates that watershe 1 characteristics (morphology, land use, and soil and vegetation types) are not necessarily consistent, dominant ccntrols on the volume of runoff produced by storms. Diffe"ences or similarities in these watershed characteristics do not cause obvious differences or similarities in runoff volume for these watersheds and storms. Additional factors, such 
as temporal and spatial variations in precipitation distribution, intensity, and volume; antecedent soil moisture; and infiltration rate and capacity also influence storm runoff. Large differences in infiltration rates and capacities occur over small ranges of soil moisture (Wells and others, 1983, p. 27). The effect of a single factor (such as land use) on the volume of storm runoff is difficult to discern because of interactions of storm and watershed characteristics.

\section{Watershed Response}

Storm hydrographs indicate the capability of a watershed to transport water on and in the land, through stream channels and lakes, and to the outlet of the watershed. Watersheds responsive to storms transport water rapidly and are characterized by hydrographs that rise rapidly, have a high peak discharge, and return to base flow rapidly. Less responsive watersheds transport water to the outlet at a slower rate. Hydrographs for these watersheds rise slowly to a lower peak discharge and return to base flow more slowly.

Hydrographs for thunderstorms and frontal storms show marked differences in response among watersheds (fig. 9). Big Slough, Hooker Creek, and Honey Creek tributary respond quickly to precipitation and often have multiple, well-defined peaks corresponding to isolated downpours of precipitation during a storm (fig. 9A, $C, D$, and $H$ ). Sulphur Creek tributary and Big Branch tributary are much less responsive to precipitation. Multiple peaks are subdued at Sulphur Creek tributary and are absent at Big Branch tributary (fig. $9 A, C, D$, and $H$ ). Pond Creek typically responds more rapidly than Sulphur Creek tributary and Big Branch tributary but less rapidly than Big Slough, Hooker Creek, and Honey Creek tributary.

Storm hydrographs for Big Slough, Hooker Creek, and Honey Creek tributary (fig. $9 F, G$ ) and for Big Slough (fig. 9A) show minor peaks that do not correspond to isolated downpours of precipitation. These minor peaks probably indicate interflow, a component of runoff that moves through the shallow saturated horizons of the soil and reaches the stream channels more slowly than overland flow. Interflow, if present, at Sulphur Creek tributary, Pond Creek, and Big Branch tributary is probably obscured by the slow release of surface runoff from the surface mine impoundments.

Watershed response, as indicated by the time from the initial rise of the hydrograph to the peak discharge, was much faster during thunderstorms than during frontal storms (table 5). Times from initial rise to peak during thunderstorms were much faster for Big Slough, Hooker Creek, and Honey Creek tributary than for the other watersheds. This indicator of watershed response failed to show differences among watersheds for frontal storms, probably because of the long duration of frontal storms. During frontal storms, the initial rise in the hydrograph may occur early in the storm, whereas peak discharge often occurs late in the storm. Honey Creek tributary generally had the shortest times from rise to peak, whereas Big Branch tributary had the longest times (table 5).

\section{Ground Water}

\section{General Description of Ground-Water Systems in West-Central Indiana}

\section{Unconsolidated Aquifers}

The unconsolidated aquifers in west-central Indiana are composed of deposits of glacial drift of Pleistocene age, alluvium of Holocene age, and spoil from coal mining. Drift covers most of the area (Martin and otr ors, 1990, p. A2-A3) and ranges from less than 50 to more than $100 \mathrm{ft}$ (feet) in thickness. The drift is composed of outwash from glacial meltwater, clayey till, and small lenses of sand and gravel in till. Glacial drift near streams may b: reworked to form alluvial deposits. Hydrologic properties of the Wabash and Eel River outwash aquifers are described by Martin and others (1990, p. A11).

Illinoian till covers most of west-centrel Indiana and consists of clay, silt, and minor amounts of sand and gravel. Till is not usually considered to be an aquifer, but because of a normally shallow water table in small upland watersheds, till is commonly a source of water for dug wells. Yields of wells in till are low, usually less tl an $3 \mathrm{gal} / \mathrm{min}$ (gallons per minute). Aquifer tests in till indicate decreasing hydraulic conductivity with depth. Hydraulic conductivity estimated from 14 slug tests at 12 wells in til ranged from $4 \times 10^{-4}$ to $9 \times 10^{-1} \mathrm{ft} / \mathrm{d}$ (feet per day), and th $:$ median was $9 \times 10^{-3} \mathrm{ft} / \mathrm{d}$ (table 6).

Differences in hydraulic conductivity of the till can be caused by fractures. Highly fractured zones commonly are found near the surface in areas of glacial till, and fractures can increase the bulk hydraulic conductivity of till by one to three orders of magnitude (Freeze and Cherry, 1979, p. 152). Vertical fractures and thin, horizontal zones of increased permeability were observed in trenches dug into till to examine the soil horizons. The fractures and horizontal zones readily produced water on excaration of the trenches. The till is recharged by infiltration ard percolation of precipitation. Relatively high hydraulic conductivity near the surface suggests that most of the horizontal flow is in the upper part of the till. Flow is primarily toward discharge areas along streams, although some water may enter the bedrock aquifers.

Lenses of sand and gravel within the till are present in some areas. These lenses are often small and discontinuous, but wells in sand and gravel lenses are capable of producing more water than wells in till. Typical yields for wells in 
Table 6. Hydraulic conductivity of till, spoil, and bedrock for six study watersheds

[BBT, unnamed tributary to Big Branch (Unreclaimed); BS, Big Slough (Unmined); HC, Hooker Creek (Unmined); HCT, unnamed tributary to Honey Creek (Reclaimed); PC, Pond Creek (Unreclaimed); SCT, unnamed tributary to Sulphur Creek (Reclaimed). $\mathrm{ft} / \mathrm{d}$, feet per day]

\begin{tabular}{|c|c|c|c|}
\hline Watershed & $\begin{array}{l}\text { Well } \\
\text { number }\end{array}$ & $\begin{array}{l}\text { Aquifer } \\
\text { material }^{1}\end{array}$ & $\begin{array}{l}\text { Calculated hydraulic } \\
\text { conductivity }{ }^{2},(\mathrm{ft} / \mathrm{d})\end{array}$ \\
\hline$\ldots$. & BS-5 & Till & $6 \times 10^{-3}$ \\
\hline BS $\ldots \ldots$ & BS-7 & do. & $4 \times 10^{-4}$ \\
\hline BS $\ldots \ldots$ & BS-9S & do. & $8 \times 10^{-2}, 2 \times 10^{-1}$ \\
\hline BS $\ldots \ldots$ & BS-9M & do. & $4 \times 10^{-3}, 1 \times 10^{-2}$ \\
\hline BS ...... & BS-10S & do. & $4 \times 10^{-2}$ \\
\hline$\ldots \ldots$ & BS-10M & do. & $8 \times 10^{-3}$ \\
\hline$\ldots \ldots$ & BS-10D & do. & $6 \times 10^{-3}$ \\
\hline$\ldots$ & BS-11 & do. & $2 \times 10^{-2}$ \\
\hline SCT & MR-6 & do. & $4 \times 10^{-3}$ \\
\hline PC $\ldots \ldots$ & PC-3 & do. & $4 \times 10^{-2}$ \\
\hline$\ldots \ldots$ & $\mathrm{PC}-4$ & do. & $7 \times 10^{-3}$ \\
\hline $\mathrm{PC} \ldots \ldots$ & $\mathrm{PC}-6 \mathrm{~S}$ & do. & $9 \times 10^{-1}$ \\
\hline HCT . & CR-1 & Spoil & $3 \times 10^{-1}$ \\
\hline НСТ $\ldots \ldots$ & CR-3 & do. & $7 \times 10^{-3}, 1 \times 10^{-2}$ \\
\hline HCT $\ldots$. & CR-5 & do. & $6 \times 10^{-2}$ \\
\hline $\mathrm{PC} \ldots \ldots$ & PC-2S & do. & $6 \times 10^{-2}$ \\
\hline PC $\ldots \ldots$ & PC-2M & do. & $1 \times 10^{-3}$ \\
\hline PC $\ldots \ldots$ & PC-2D & do. & $2 \times 10^{-3}$ \\
\hline BBT $\ldots \ldots$ & MU-1 & do. & $2 \times 10^{-2}$ \\
\hline HC . & CS-2 & Bedrock & $1 \times 10^{-2}$ \\
\hline HC $\ldots \ldots$ & CS-3 & do. & $3 \times 10^{-2}$ \\
\hline $\mathrm{HC} \ldots \ldots$ & HC-2 & do. & $8 \times 10^{-1}$ \\
\hline HC $\ldots \ldots$ & $\mathrm{HC}-3$ & do. & $1 \times 10^{-1}$ \\
\hline SCT $\ldots \ldots$ & MR-2 & do. & $4 \times 10^{-2}, 4 \times 10^{-2}$ \\
\hline SCT $\ldots \ldots$ & MR-3 & do. & $\underset{9 \times 10^{-3}}{3 \times 10^{-3}, 4 \times 10^{-3}, 6 \times 10^{-3}}$ \\
\hline SCT $\ldots \ldots$ & MR-6B & do. & $2 \times 10^{-2}, 3 \times 10^{-2}$ \\
\hline SCT $\ldots \ldots$ & MR-6SS & do. & $2 \times 10^{-3}$ \\
\hline SCT $\ldots \ldots$ & MR-7 & do. & $2 \times 10^{-4}, 3 \times 10^{-4}, 4 \times 10^{-3}$ \\
\hline $\mathrm{PC} \ldots \ldots$ & PC-1SS & do. & $8 \times 10^{-3}$ \\
\hline PC $\ldots \ldots$ & PC-5 & do. & $3 \times 10^{-2}, 2 \times 10^{-1}$ \\
\hline PC $\ldots \ldots$ & PC-7 & do. & $5 \times 10^{-3}$ \\
\hline
\end{tabular}

${ }^{1}$ Till contains various amounts of sand and gravel.

${ }^{2}$ Hydraulic conductivity estimated from slug tests by using the method of Bouwer and Rice (1976, p. 424-425).

${ }^{3}$ Multiple values of hydraulic conductivity at a single well result from using different recovery times for estimating hydraulic conductivity.

sand and gravel lenses range from 3 to $10 \mathrm{gal} / \mathrm{min}$ (Banaszak, 1985, p. 52). The lenses of sand and gravel have hydraulic conductivities several orders of magnitude greater than the surrounding till and act as confined aquifers. Although few lenses of sand and gravel were discovered by drilling for this study, their presence in this area has been documented (Watkins and Jordan, 1962a,b, 1963, p. 6). Larger, more continuous sand and gravel aquifers often are found in bedrock valleys that have been buried by glacial drift. Yields from wells in these confined aquifers range from 5 to $75 \mathrm{gal} / \mathrm{min}$ (Banaszak, 1985, p. 52).

Spoil from mining coal is a heterogeneous mixture that consists primarily of till and shale but commonly contains smaller amounts of soil, siltstone, sandstone, limestone, and (or) coal. Composition, compaction, and distribution of these materials within the spoil are usually highly variable, are largely unknown, and have significant effects on the hydrologic properties of the spoil. S noil has greater volume and porosity than the premining overburden but may or may not have a greater hydraulic condictivity. Weiss and Razem (1984, p. 554) reported values of hydraulic conductivity for spoil in Ohio that ranced from 0.3 to $5.4 \mathrm{ft} / \mathrm{d}$, as much as two orders of magnitude greater than the premining overburden. L.L. Bobo and S.E. Eikenberry (U.S. Geological Survey, written commun., 1980) estimated hydraulic conductivities as great as $130 \mathrm{f} \div / \mathrm{d}$ at the reclaimed mine that contains the Honey Creek tributary watershed. However, the hydraulic conductivity of spoil estimated for this study from eight slug tests at seven wells ranged from $1 \times 10^{-3}$ to $3 \times 10^{-1} \mathrm{ft} / \mathrm{d}$, and the median was $1.5 \times 10^{-2} \mathrm{ft} / \mathrm{d}$ (table 6 ). These values of hydraulic conductivity for spoil are similar to those for till.

The large water-storage capacity of spoil has been well documented (Corbett, 1965, p. 1-8; Grubb an 1 Ryder, 1972, p. 32; Agnew and Corbett, 1973, p. 164-16F; Curtis, 1977, p. 152-153; 1978, p. 18; Cartwright and Hunt, 1981, p. 9; Razem, 1984, p. 33; Banaszak, 1985, p. 55). A water table usually develops in the spoil, but under various hydrogeologic conditions the spoil may remain un aturated or nearly so (Lindorff, 1980, p. 35; Razem, 1984, p. 26, 31).

Hydrologic properties of the spoil are influenced by methods of mining and reclamation. Area mining employs draglines or large shovels to strip the overburden and expose the coal. Stripped overburden is cast in pil \%s where coal has been removed. Boulders and gravel may roll to the base of the piles and form zones of high hydraulic conductivity. In unreclaimed mines, these spoil piles are left as they were created. In reclaimed mines, the spoil ridges are graded to a level or gently rolling surface by bulldozers. Movement of heavy machinery compacts the surface layers of the spoil, thereby reducing shallow hydraulic conductivity and impeding infiltration. Recharge to the spoil is by infiltration of precipitation on the spoil surface, $t y$ percolation of water from surface runoff that has collected in depressions or impoundments above the water table, and (or) by lateral flow from adjacent, unmined aquifers. Discharge is generally toward lakes or streams that cut below the water table in the spoil, although some water may flow to deeper aquifers.

\section{Consolidated Aquifers}

The consolidated bedrock aquifers in west-central Indiana are composed primarily of shale, siltstone, sandstone, coal, and limestone of Pennsylvanian age and limestones of Mississippian age (Martin and others, 1990, p. A2, A11). Ground water flows in the bedrock primarily in fractures, along bedding planes, in the cleats (joints) of coal seams, and in unfractured sandstone having sufficient primary permeability (Heath, 1984, p. 44). 
Shales and siltstones commonly are considered confining beds, but fractures caused by jointing, faulting, or blasting can reduce or destroy the confining effect of these rocks and increase their hydraulic conductivities by several orders of magnitude. Schubert (1980, p. 64-65) presented compelling evidence of fracture-dominated flow in the bedrock of eastern coal-mining regions. The size and amount of fractures and, therefore, the hydraulic conductivity caused by fractures generally decrease with depth. On the basis of this evidence, fractures probably are also a significant hydrologic control in bedrock aquifers of westcentral Indiana. Many wells in the study area are finished in shale and yield enough water for domestic needs. Waterbearing zones also occur along bedding planes and at contacts between different rock types (Stoner, 1983, p. 130). Hydraulic conductivity estimated from 20 slug tests at 12 wells in bedrock ranged from $2 \times 10^{-4}$ to $8 \times 10^{-1} \mathrm{ft} / \mathrm{d}$, and the median was $9.5 \times 10^{-3} \mathrm{ft} / \mathrm{d}$ (table 6 ).

As many as six basal sandstone members of cyclothems (repetitive cycles of deposition) are important aquifers in the study area (Cable and others, 1971, p. 5; Cable and Robison, 1973, p. 9). The sandstone aquifers are either widespread, thin but discontinuous beds associated with deltaic deposits or narrow, thick beds associated with channel deposits. Channel sandstones offer greater potential for ground-water yield because of their greater thickness, although yields of either type can be less than $1 \mathrm{gal} / \mathrm{min}$. Average yields of the various sandstone aquifers range from approximately 3 to $9 \mathrm{gal} / \mathrm{min}$; yields rarely exceed 20 gal $/ \mathrm{min}$ (Cable and others, 1971, table 2, fig. 3). Average hydraulic conductivities range from 0.6 to $3.5 \mathrm{ft} / \mathrm{d}$ (Cable and others, 1971, table 2).

The values of hydraulic conductivity reported by Cable and others (1971) are greater than those estimated for bedrock in this study. The differences in hydraulic conductivity may be attributed to differences in the methods and (or) types of wells used to determine hydraulic conductivity. Cable and others (1971) did not report their methods, but hydraulic conductivity probably was estimated by specific-capacity tests, whereas slug tests (Bouwer and Rice, 1976) were used in this study. Cable and others (1971) used water-supply wells to determine hydraulic conductivity, whereas this study used observation wells. Water-supply wells typically are cased to the surface of the bedrock, but observation wells typically are cased into the bedrock. If fractures are more common at shallow depths, water-supply wells will intercept more fractures than observation wells. Finally, because of use, water-supply wells usually are developed to a greater degree than observation wells.

In addition to basal sandstones, coal seams have been identified as aquifers in sections of the cyclothems lacking more permeable strata. Flow in a coal seam is along cleats that have developed in the seam. Banaszak $(1980$, p. 236 , 239) discussed the importance of stratigraphy in determin- ing the water-bearing potential of shallow coals. To be an aquifer, coal seams must be (1) hydrologically connected (at some point) to permeable strata that recharge the seam and (2) associated with a plastic underclay that perches ground water in the seam. Both stratigraphic conditions are necessary for the development of shallow, perched aquifers in coal seams. If a coal seam is part of a dee eer, saturated section of the bedrock, the presence of a plasti? underclay is not necessary. Because coal seams are usually underlain by a relatively homogeneous underclay (Whitla ${ }^{+} \mathrm{h}, 1933$, p. 63 ; Banaszak, 1980 , p. 236), the presence or absence of a recharging unit is critical in producing coal aquifers. Yields of wells in coal seams range from 1 to $10 \mathrm{gal} / \mathrm{min}$ (Banaszak, 1980, p. 235).

Hydrogeology of the bedrock aquifers is complex, and the occurrence of perched, unconfined, and confined bedrock aquifers in the same section is possible (Banaszak, 1985 , p. 52-53). Perched bedrock aquifers oc ?ur at shallow depths where underclays inhibit the downward flow of water. If recharge through the underclay is less than discharge from the underlying formation, uns turated areas result. Unconfined bedrock aquifers occur at the outcrop or at the subcrop where they are hydrologically connected to the water table in permeable unconsolidated deposits. Where the unconsolidated deposits are much less permeable than the underlying bedrock, the shallow bedrock aquifers are confined. At depth, the bedrock aquifers are confined. Underclay is the principal confining strata.

The bedrock aquifers are recharged by direct infiltration and percolation of precipitation at th: outcrop or through drift or mine spoil at the subcrop or $t y$ percolation of surface water in upland lakes or depression. Flow in the shallow bedrock is primarily local, and topography controls the local flow systems. Flow paths are relatively short; recharge occurs in the uplands, and flow discharges to streams that cut near the surface of the bedrock. Flow deeper in the bedrock is primarily regional ard follows the southwest dip of the strata to points of discharge along the Wabash and Eel Rivers (fig. 1).

\section{Description of Ground-Water Systems in the Study Watersheds}

Big Slough

Information on lithology and stratigraphy at and near the Big Slough watershed was obtained from shallow test holes drilled to bedrock. Approximately 15 to $45 \mathrm{ft}$ of silty clay till overlies shale and sandstone of the Ponnsylvanian Linton Formation (Martin and others, 199C, fig. 14, p. A21). Fourteen observation wells were installed in till, and three wells were installed in bedrock (fig. 10). Hydraulic conductivity of till measured at eight wells ranged from $4 \times 10^{-4}$ to $2 \times 10^{-1} \mathrm{ft} / \mathrm{d}$ (table 6 ). 


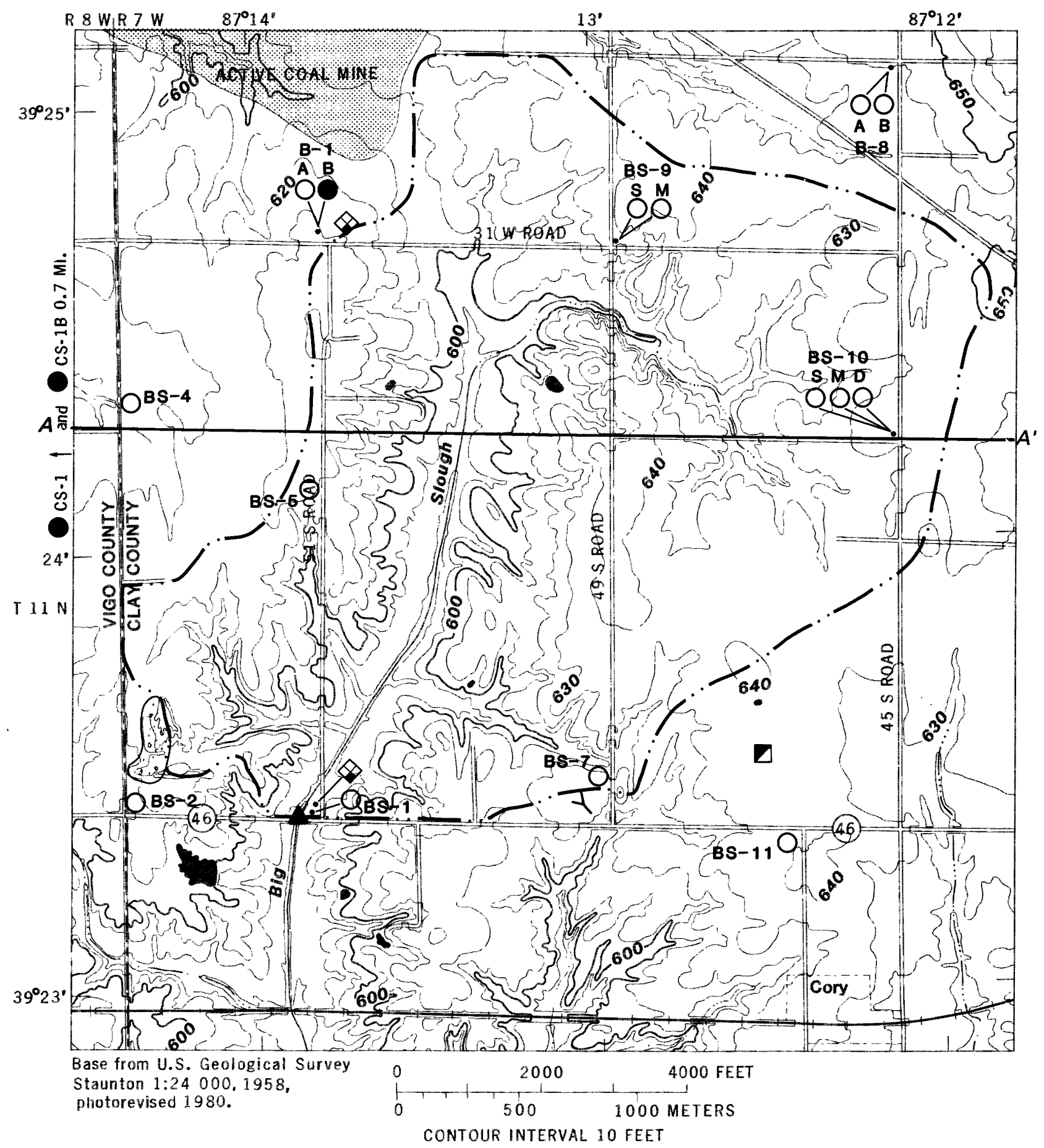

NATIONAL GEODETIC VERTICAL DATUM OF 1929

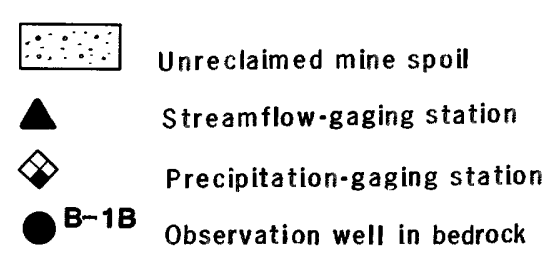

EXPLANATION

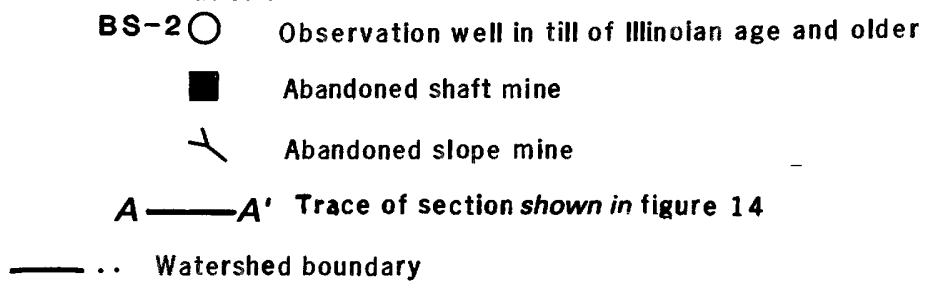

Figure 10. Big Slough watershed and data-collection sites. 


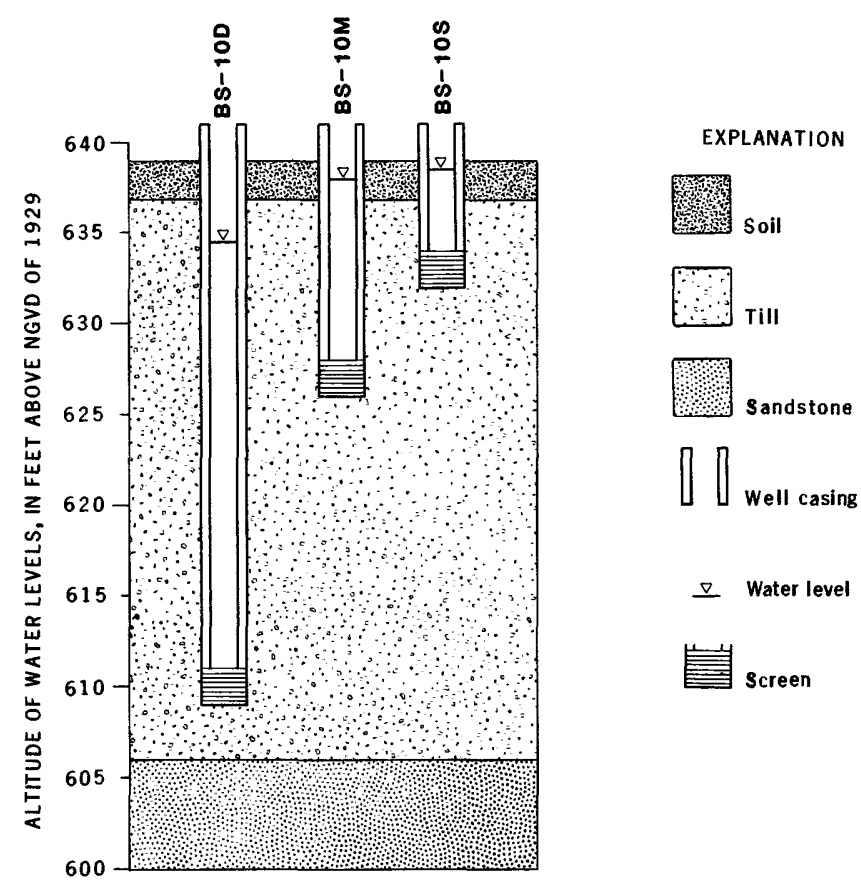

Figure 11. Distribution of water levels in nest of wells finished in till at Big Slough, June 17, 1982.

Aquifer tests indicated that till near land surface had greater hydraulic conductivity than till near bedrock. The majority of horizontal flow probably occurs in the upper part of the till because of the greater conductivity of this zone. Flow is horizontal in zones of greater permeability toward points of discharge but is vertical in zones of lesser permeability toward a zone that provides a more permeable pathway to a discharge area. Water-level data at a site having multiple wells also indicate greater conductivity in the upper till. The distribution of head in the nest of wells at BS-10 (fig. 11) shows that most head loss is in the lower zone, whereas little head loss is in the upper zone. This pattern of head loss indicates the dominance of the horizontal component of flow in the upper till and of the vertical component of flow in the lower till.

The till is recharged by direct infiltration of precipitation to the water table, which is usually within 2 to $6 \mathrm{ft}$ of land surface (fig. 12). The hydrograph of an upland well, BS-4 (fig. 13), shows a seasonally fluctuating water table that generally is recharged in winter and spring when crops and other vegetation are dormant and that declines in summer and fall when evapotranspiration is high. Wells finished in till in the upland recharge areas generally have similar hydrographs and show water-level fluctuations of 2 to $6 \mathrm{ft}$. The deepest well finished in till (BS-10D) exhibited the least fluctuation in water levels (fig. 13). Shallow ground water is discharged into Big Slough or may move downward into the bedrock (fig. 14).
The surface-water and shallow ground-v'ater systems are well connected in the flood plain of Big S'ough. Daily mean water levels in well BS-1 (a shallow well approximately $200 \mathrm{ft}$ from the streamflow-gaging station) are closely associated with peak and low streamflows. The elevation of the water level in BS-1 is generally 2.5 to 5.5 $\mathrm{ft}$ above the elevation of the stream and indica+es that water typically flows from the shallow system into Big Slough (fig. 13).

The Pennsylvanian bedrock underlying the till at Big Slough is an erosional surface cut into the Linton Formation and consists mainly of shale and sandstone. The Seelyville Coal Member (III) marks the top of the underlying Staunton Formation (Martin and others, 1990, fig. 14, p. A21). Water levels in a bedrock well open to the Linton Formation (CS-1) and a bedrock well open to the Staunton Formation (CS-1B) indicate confined aquifer conditions in both formations (fig. 15). Water levels in well CS-1 rise to within $1 \mathrm{ft}$ of land surface and suggest upward movement of water in the shallow bedrock toward points of surfase discharge. Water levels in well CS-1B are much deeper, about $90 \mathrm{ft}$ below land surface and indicate little hydraulic connection between formations. Underclay below the Seolyville Coal Member (III) probably provides a barrier to hydraulic continuity between aquifers and acts as a confining layer for water in the Staunton Formation (fig. 15). Yearly fluctuations of the water levels in both wells are small, about 2.5 $\mathrm{ft}$ in CS-1 and about $1 \mathrm{ft}$ in CS-1B. Wat $r$ levels are generally highest in spring and lowest in fall.

The bedrock is recharged by downward movement of water from the overlying till (fig. 14). The direction of shallow flow in the bedrock is controlled by topography of the land and bedrock. Shallow flow in the bedrock probably discharges to Big Slough because (1) the stream has cut into the till and is near the bedrock surface, (2) the elevation of the stream is below the elevation of the bedroc's, and (3) the surface of the bedrock to the east of $\mathrm{Bir}$. Slough is sandstone. The quantity and direction of flow deep in the bedrock are controlled primarily by the extent of fracturing and by the structure and lithology of the roc'r. Underclay impedes the vertical flow of water betweer formations, predominantly in the downward direction at Big Slough (fig. 14). Regional flow follows the southwest dip of the bedrock and probably discharges to the Wabash and Eel Rivers. If confining layers (underclay and unfractured shale) are thin or absent, water deep in the bedrock may discharge to the surface.

\section{Hooker Creek}

Test drilling and domestic well logs at the Hooker Creek watershed show 10 to $100 \mathrm{ft}$ of glacial drift covering shale and sandstone of the Dugger Formatior (Martin and others, 1990, fig. 16, p. A25). The drift is predominantly a 

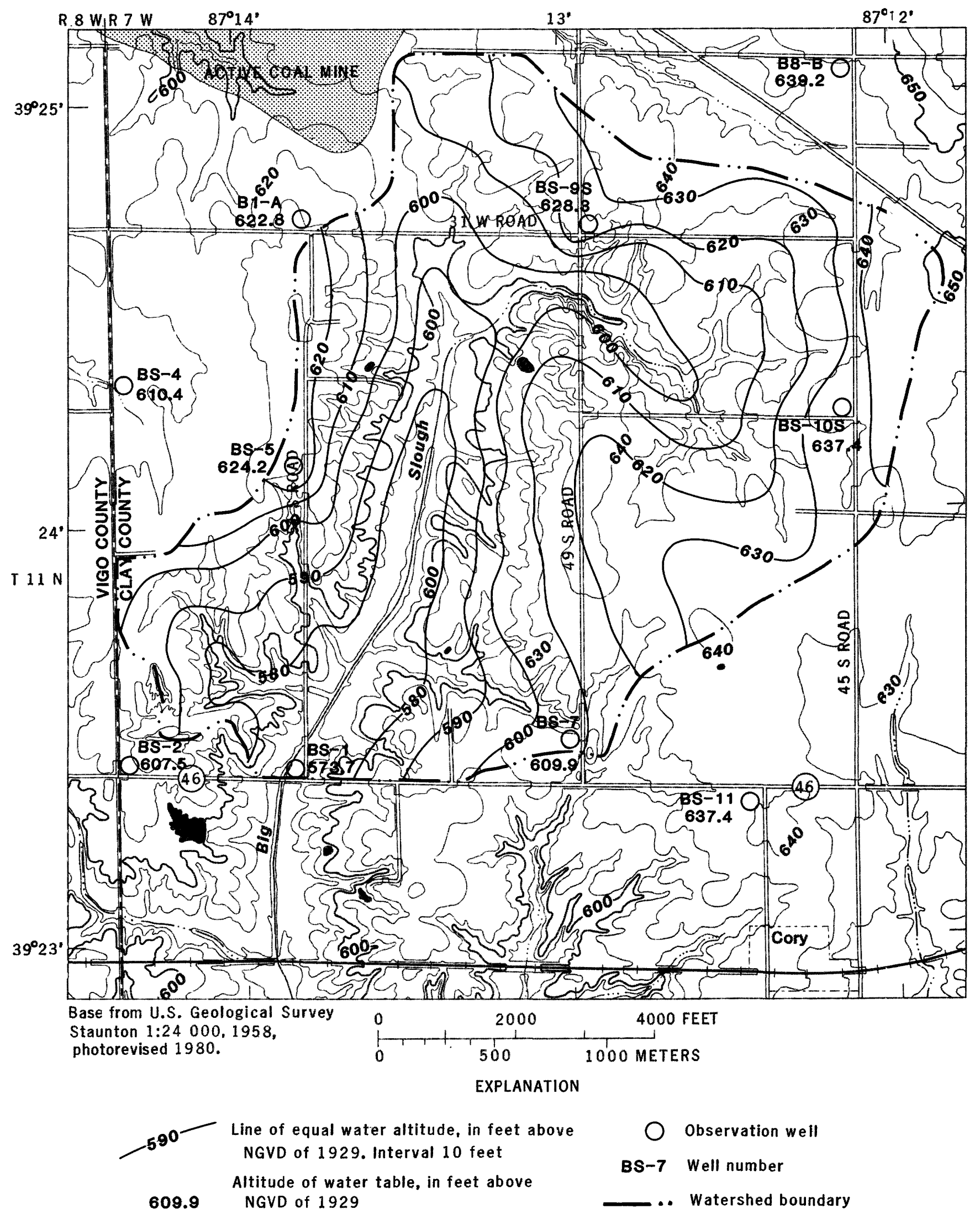

Figure 12. Altitude of water table at Big Slough, May 18, 1982. 

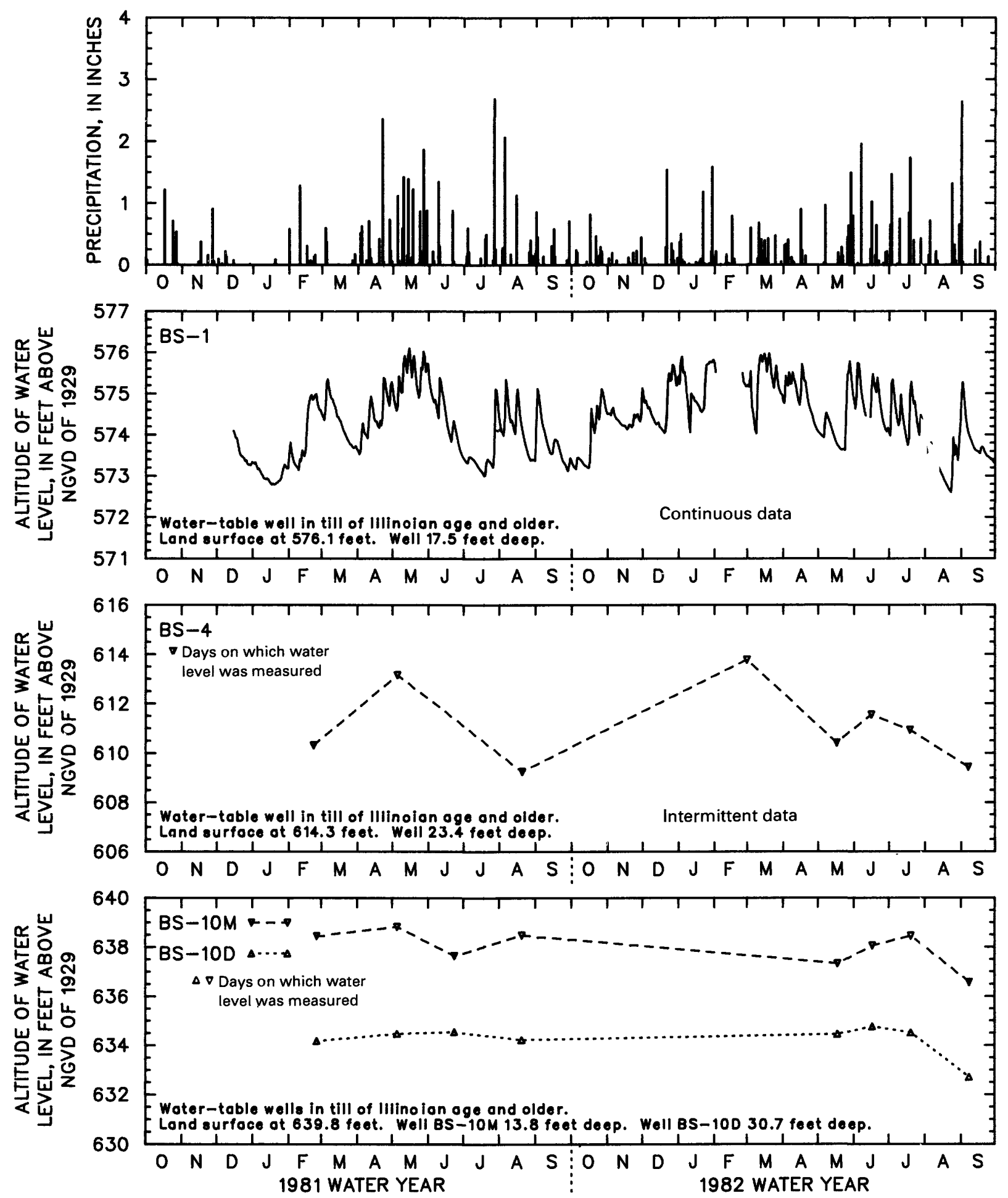

Figure 13. Daily precipitation and ground-water levels at Big Slough, 1981 and 1982 water years. Interruption in water-level data indicates no data available.

silty clay till containing small amounts of sand and gravel, although some loess is present. Well logs indicate a buried bedrock valley trending north-south beneath the Hooker Creek watershed. A bedrock well (HC-2) drilled west of the watershed boundary encountered approximately $15 \mathrm{ft}$ of sand and gravel in the buried valley at a deptl of about 60 $\mathrm{ft}$. Three observation wells were installed in till, and four wells were installed in bedrock (fig. 16). 


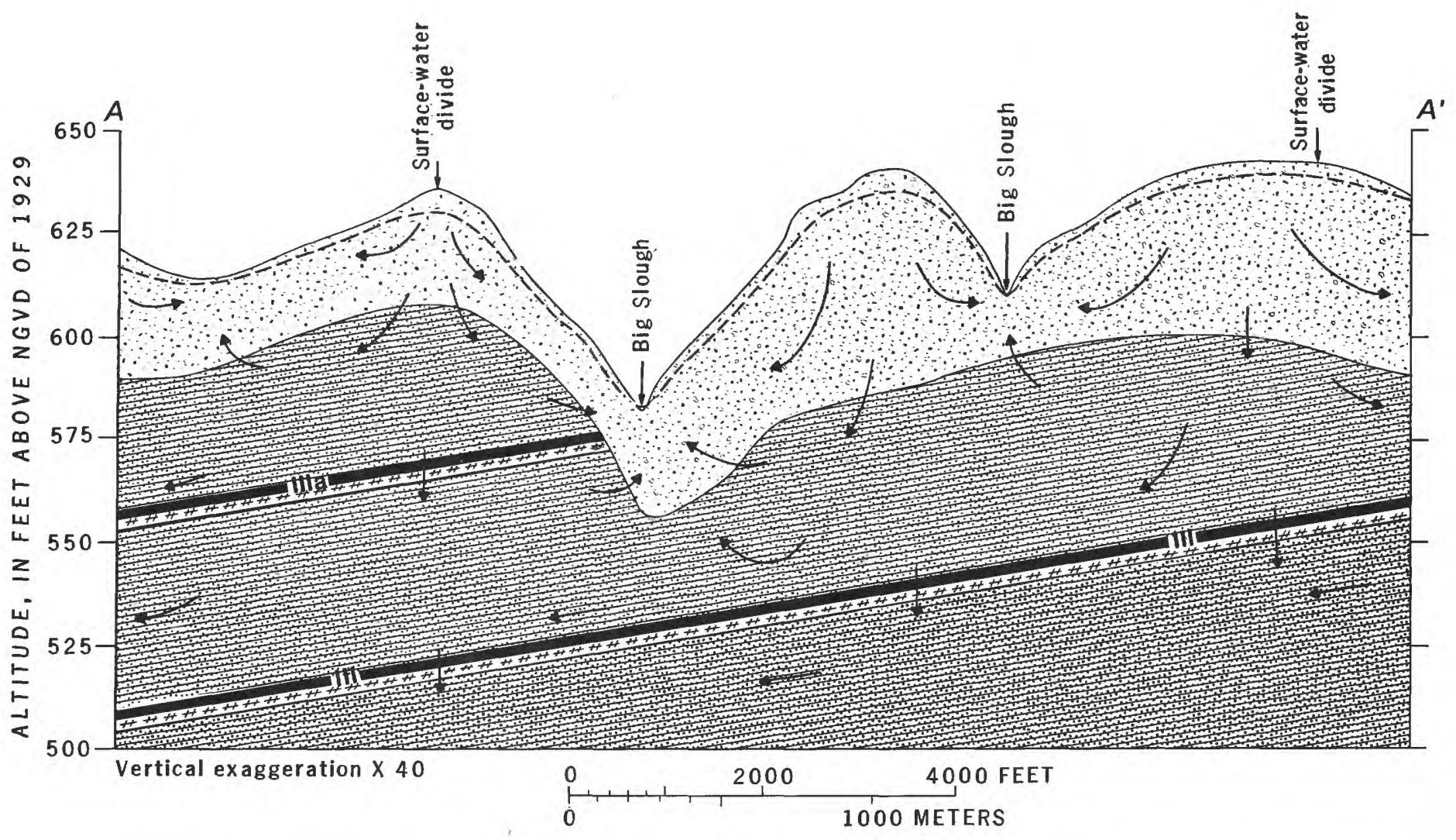

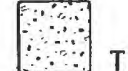

Till

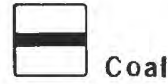

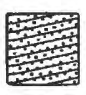

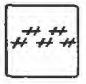

Shale and sandstone

Underclay

EXPLANATION

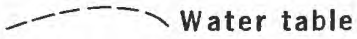

Colchester Coal Member of

Illa the Linton Formation

Figure 14. Hydrogeologic section showing generalized stratigraphy and direction of ground-water flow at Big Slough. Location of section $A-A^{\prime}$ shown in figure 10.

Water levels in the till are generally within 1 to $6 \mathrm{ft}$ of the land surface and fluctuate only about 1 to $2 \mathrm{ft}$. The till is recharged by infiltration of precipitation, and discharge is to Hooker Creek, although some water probably moves downward into the bedrock.

The surface- and ground-water systems at Hooker Creek are not well connected. A shallow well (HC-1B) within $20 \mathrm{ft}$ of Hooker Creek maintained a water level approximately $1 \mathrm{ft}$ above stream level except during peak flows. Water levels in the well fluctuated much less than those in the stream, probably because of the low hydraulic conductivity of the till.

Beneath the till, Pennsylvanian bedrock of the Dugger Formation is predominantly shale in the upper part and about $25 \mathrm{ft}$ of sandstone at the base. The drilling of many local wells through the Dugger Formation into the underlying Petersburg Formation indicates an insufficient supply of water in the Dugger Formation. Hydraulic conductivities calculated for four wells open to the Dugger, Petersburg, and (or) Staunton Formations ranged from $1 \times 10^{-2}$ to
$8 \times 10^{-1} \mathrm{ft} / \mathrm{d}$ (table 6). Although the bedrock wells were open to different formations or combinations of formations, fluctuations of water levels in these wells were similar, about $1.5 \mathrm{ft}$. Water levels in all of the bedrock wells indicated confined conditions; underclay and unfractured shale act as confining layers.

The bedrock is recharged by water in the overlying till. Some water in the shallow bedrock probably discharges to Hooker Creek, and some probably moves downward to become part of the regional flow system. Water deep in the bedrock (beneath the shallowest underclay) probably flows southwest, the direction of the structural dip, to discharge areas along the Wabash River.

\section{Unnamed Tributary to Honey Creek}

Observation wells were installed in nine test holes drilled in or near the Honey Creek tributary watershed. Eight observation wells were finished in reclaimed mine spoil, and one well was finished in bedrock (fig. 17). Well logs showed 60 to $95 \mathrm{ft}$ of mine spoil overlying underclay, 


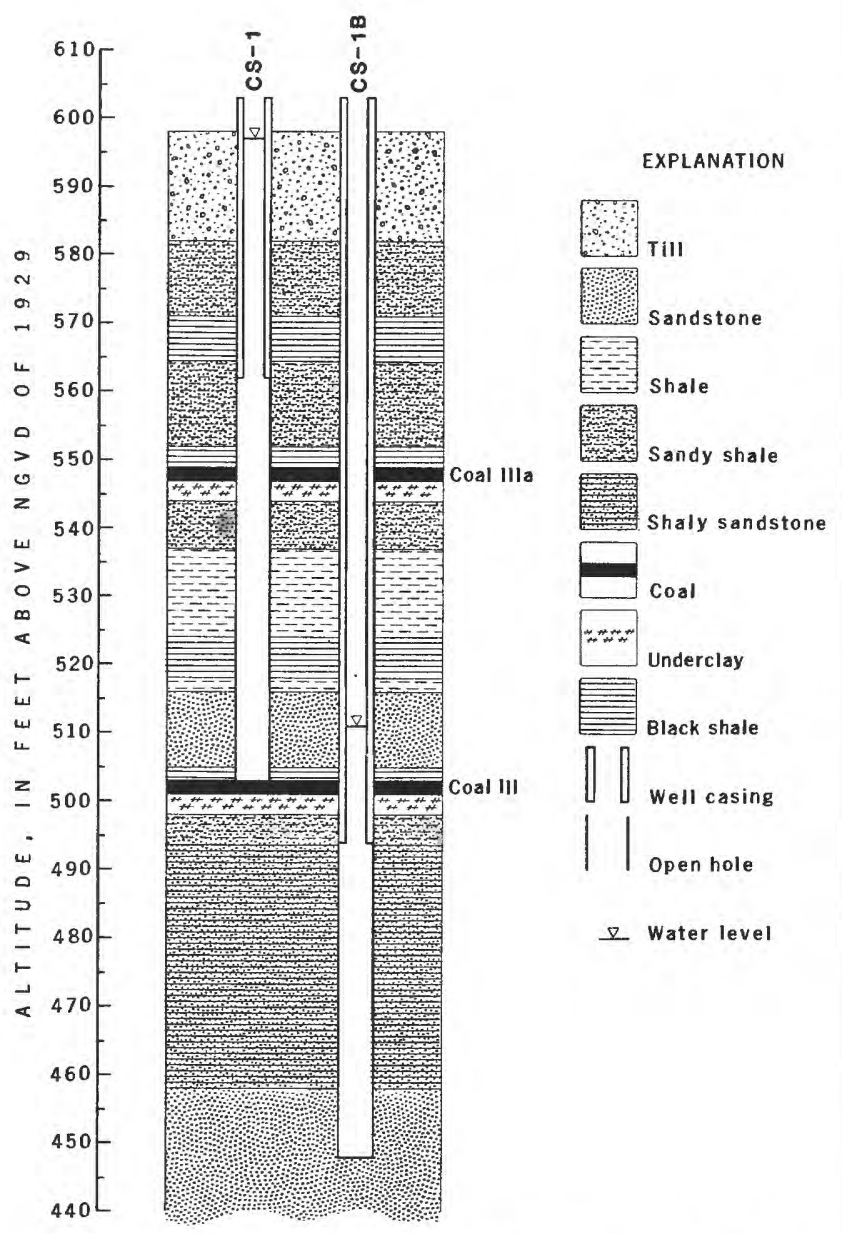

Figure 15. Geologic column showing distribution of water levels in well open to the Linton Formation (CS-1) and well open to the Staunton Formation (CS-1B) near Big Slough, June 17, 1982.

shale, sandstone, limestone, and an unnamed coal of the Staunton Formation (Martin and others, 1990, fig. 18, p. A27).

Hydraulic conductivity calculated from four slug tests at three wells in spoil ranged from $7 \times 10^{-3}$ to $3 \times 10^{-1} \mathrm{ft} / \mathrm{d}$ (table 6). Slug tests from a previous study at this mine site indicate hydraulic conductivities as great as $130 \mathrm{ft} / \mathrm{d}$ in the spoil (L.L. Bobo and S.E. Eikenberry, U.S. Geological Survey, written commun., 1980). The large variation in hydraulic conductivity is probably related to methods used in placing and compacting the spoil.

Prior to August 1981, water levels in the spoil were controlled primarily by the water level in a final-cut lake immediately south of the watershed (fig. 17). A mining company maintained the lake level at an altitude ${ }^{1}$ of $540 \pm 10 \mathrm{ft}$ above the National Geodetic Vertical Datum of

\footnotetext{
${ }^{1}$ Altitude in this report refers to the distance above or below the NGVD of 1929.
}

1929 (NGVD of 1929) by pumping from the lake. Water levels in well CR-1 were above lake levels and fluctuated with lake levels and periods of pumping (fig. 18). Groundwater levels at well R-7A did not fluctuate with lake levels (fig. 18) but may have been associated with water levels in the impoundment created by a road $100 \mathrm{ft}$ northeast of well R-7A (fig. 17). Fluctuations in ground-water levels in the spoil were about $10 \mathrm{ft}$, and the water table was generally 25 to $45 \mathrm{ft}$ below land surface (figs. 17, 19).

In August 1981, pumping from the final-cut lake was discontinued, and lake levels began to rise. Lake levels rose about $40 \mathrm{ft}$ and reached equilibrium in March 1982. Water levels in wells finished in spoil rose 6 to $40 \mathrm{ft}$ in association with rising lake levels; the amount of rise decreased away from the lake (figs. 17, 18). After lake and ground-water levels reached equilibrium, fluctuations in ground-water levels in the spoil ranged from about 1 to $4.5 \mathrm{ft}$. The smallest fluctuations were at wells near the lake, and the largest fluctuations were at wells away from the lake. Although ground-water levels rose 6 to $40 \mathrm{ft}$ throughout the watershed (figs. 19, 20), the water table remained at least $4.5 \mathrm{ft}$ below the stream channel and did not affect flow in the ephemeral stream.

Rising lake levels appear to have altered the location of the ground-water divide. Prior to August 1981, the ground-water divide was north of well CR-6 (fig. 19). After March 1982, the ground-water divide was between wells CR-5 and CR-6 (fig. 20). Inward migration of the groundwater divide is a response to rising lake levels, which decrease the hydraulic gradient and the amount of flow to the lake.

The spoil is recharged by infiltration of precipitation or by percolation of surface water that has collected in depressions. The shallow ground water flows toward and through the final-cut lakes south of the watershed to points of discharge at an active mine about $1 \mathrm{mi}$ south-southeast of the watershed.

Bedrock of the Staunton Formation is separated from the mine spoil by 2 to $6 \mathrm{ft}$ of underclay. Water levels in a well set in spoil just below the water table ( $\mathrm{R}-7 \mathrm{~A})$ are about $2 \mathrm{ft}$ higher than those in a well set in spoil just above the underclay (R-7B; fig. 17) and indicate a downward component of flow in the spoil (Bobo and Eikenberry, 1982, p. 39). Water levels in a well set in the Staunton Formation (R-7C; fig. 17) are generally 20 to $30 \mathrm{ft}$ below those in the spoil but rise above the bedrock. The underclay confines water in the bedrock and impedes downward flow. Water in the bedrock beneath Honey Creek tributary probably discharges to the active mine pit south-southeast of the watershed.

$$
\text { Unnamed Tributary to Sulphur Creek }
$$

Test drilling in and near the Sulphur Creek tributary watershed showed 20 to $60 \mathrm{ft}$ of unconsolidated material 


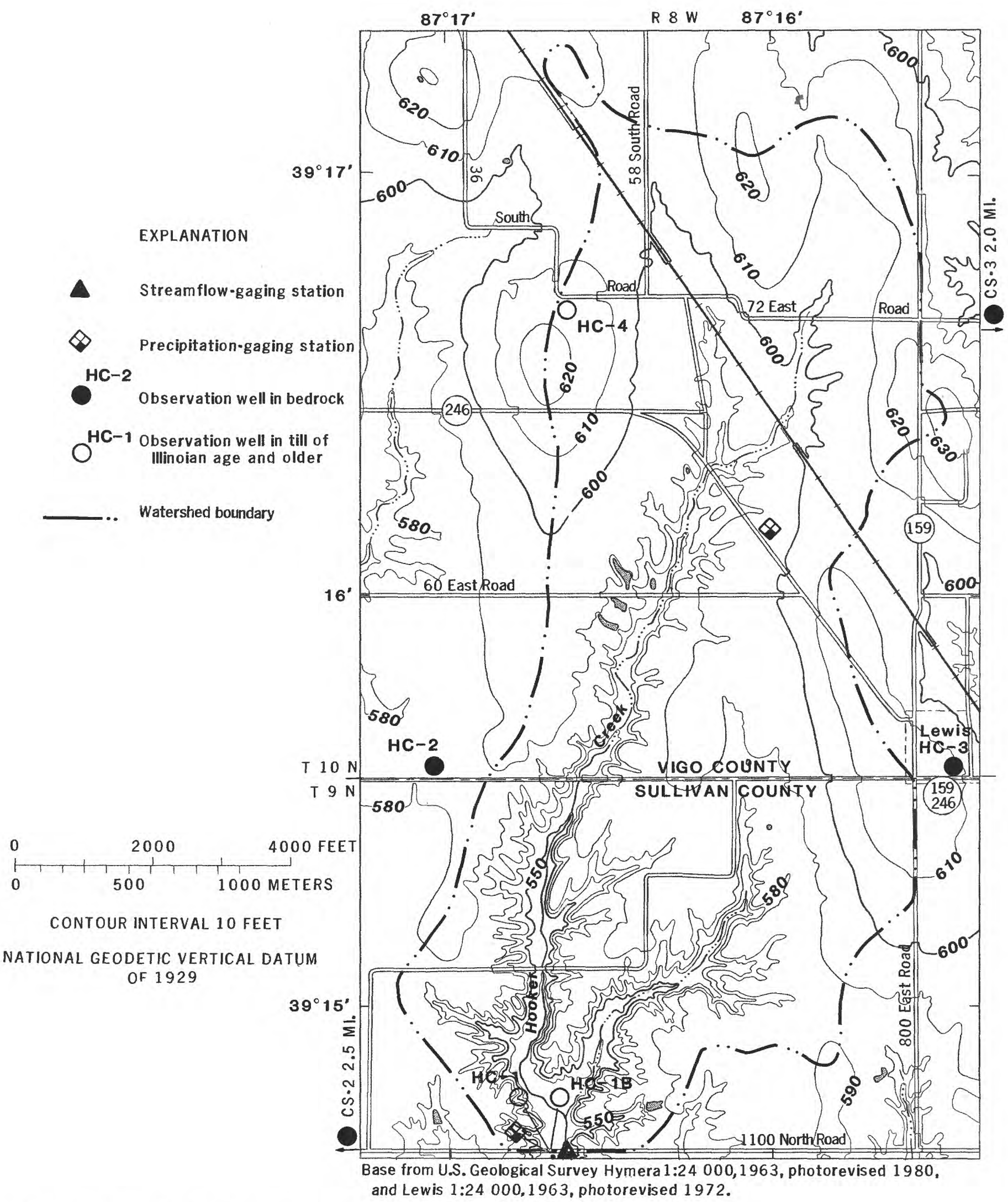

Figure 16. Hooker Creek watershed and data-collection sites. 


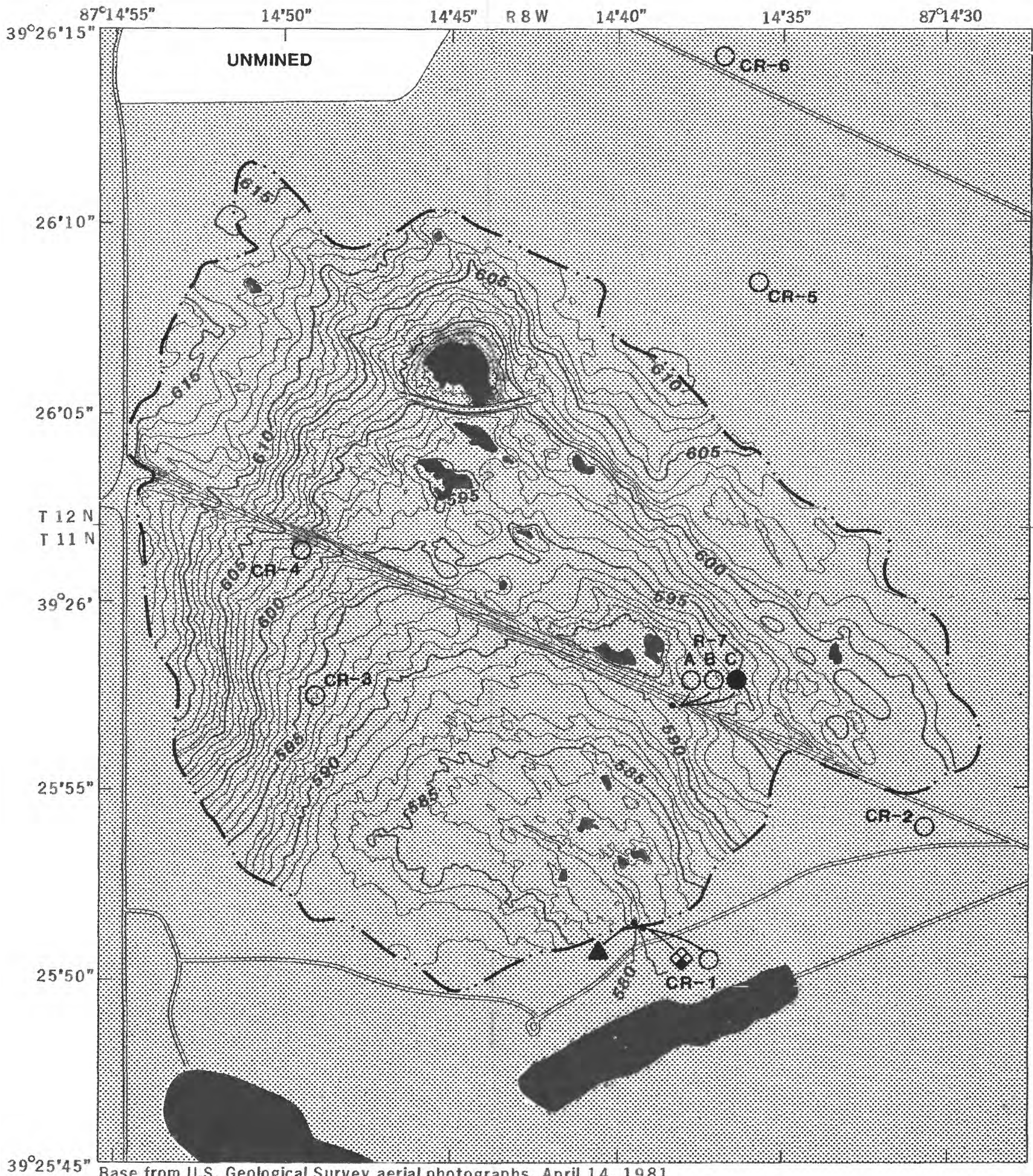

$39^{\circ} 25^{\prime \prime} 45^{\prime \prime}$ Base from U.S. Geological Survey aerial photographs, April 14, 1981

$$
\begin{aligned}
& \qquad, 200,400,600,800 \text { FEET } \\
& 0000150,200 \text { METERS } \\
& \text { CONTOUR INTERVAL } 1 \text { FOOT }
\end{aligned}
$$

NATIONAL GEODETIC VERTICAL DATUM OF 1929

EXPLANATION

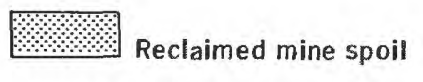

- Watershed boundary $\triangle$ Streamflow-gaging station

Precipitation-gaging station

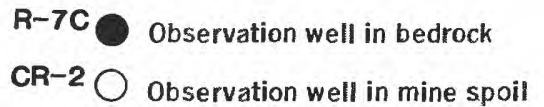
CR-2 Observation well in mine spoil

Figure 17. Unnamed tributary to Honey Creek watershed and data-collection sites. 

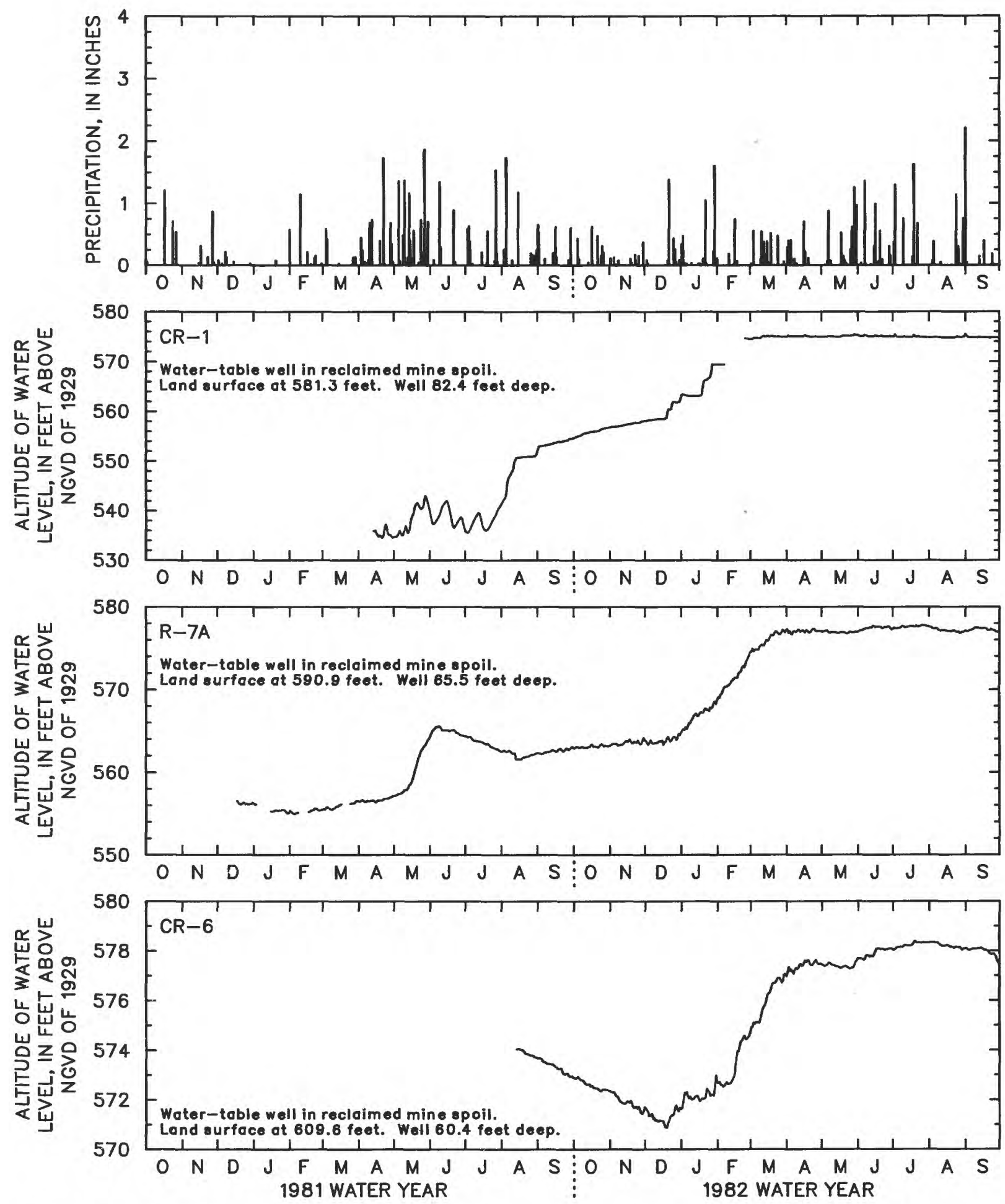

Figure 18. Daily precipitation and daily mean ground-water levels at unnamed tributary to Honey Creek, 1981 and 1982 water years. Interruption in water-level data indicates no data available.

overlying rocks of the Dugger and Petersburg Formations (Martin and others, 1990, fig. 20, p. A30). The unconsolidated material is composed primarily of 0 to $60 \mathrm{ft}$ of mine spoil or 0 to $30 \mathrm{ft}$ of till. More than 90 percent of the watershed is covered by mine spoil. The bedrock is typical of Pennsylvanian strata, mostly shale, sandstone, and 

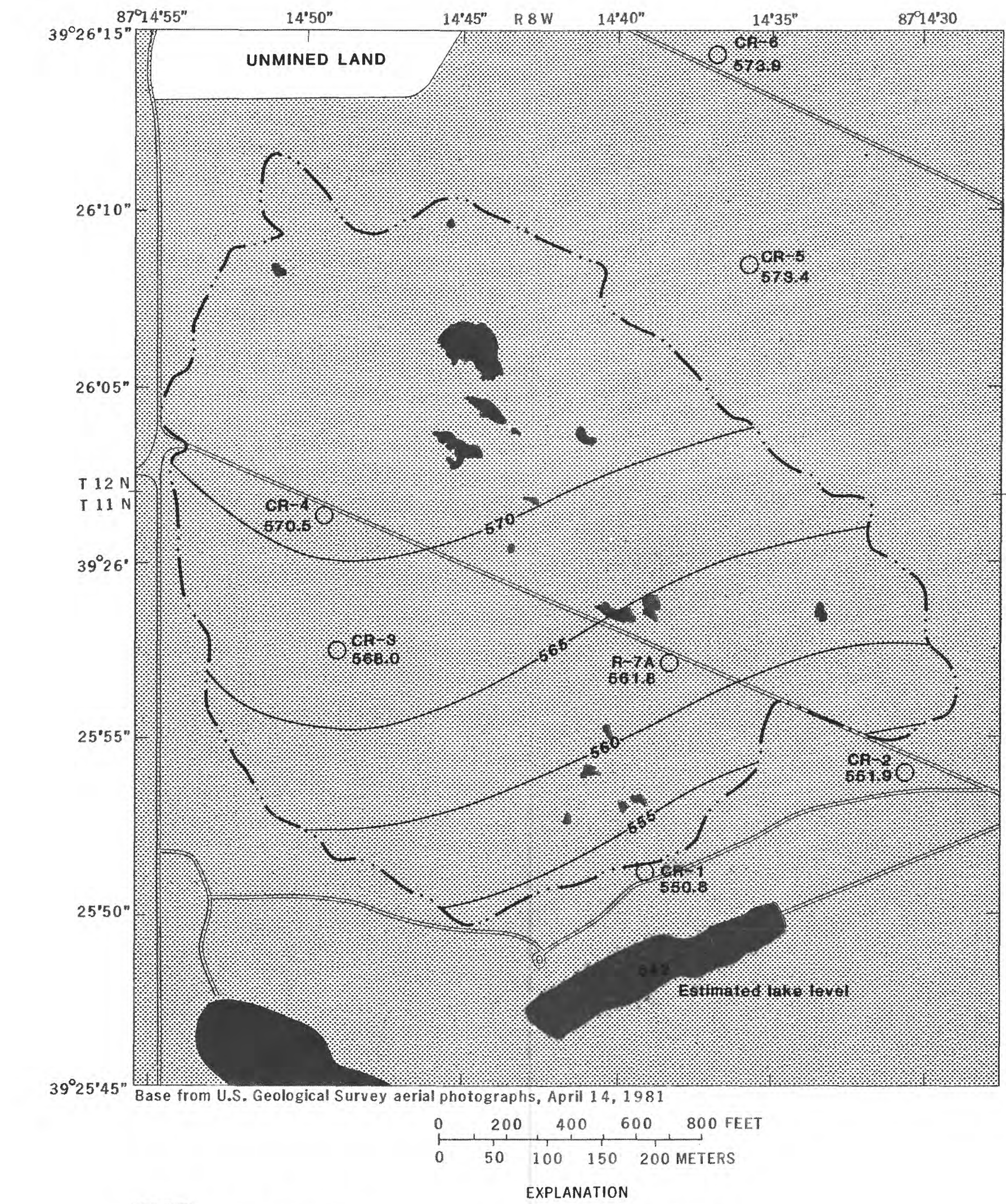
Observation well

CR-2 Well number

$-5_{60}$ - Line of equal water altitude, in feet
above NGVD of 1929 . Interval 5 feet

551.9 Altitude of water table, in feet above NGVD of 1929 -.. Watershed boundary

Figure 19. Altitude of water table at unnamed tributary to Honey Creek, August 20, 1981. 


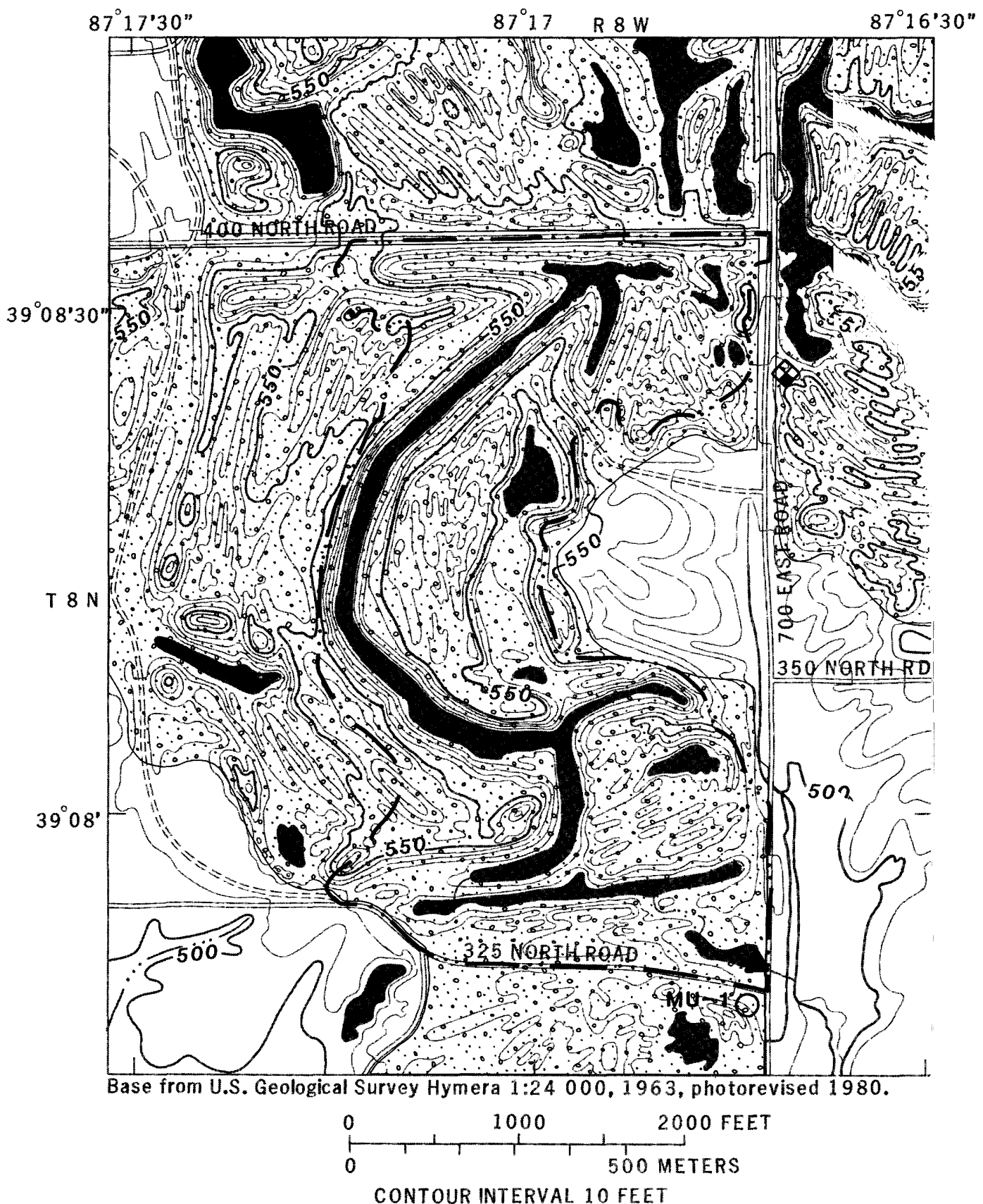

NATIONAL GEODETIC VERTICAL DATUM OF 1929 EXPLANATION

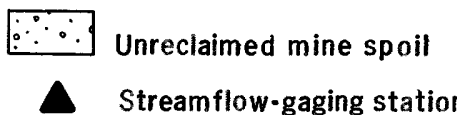

\section{Precipitation-gaging station $M U-1 \bigcirc$ observation well in spoil}

Watershed boundary

Figure 30. Unnamed tributary to Big Branch watershed and data-collection sites. 

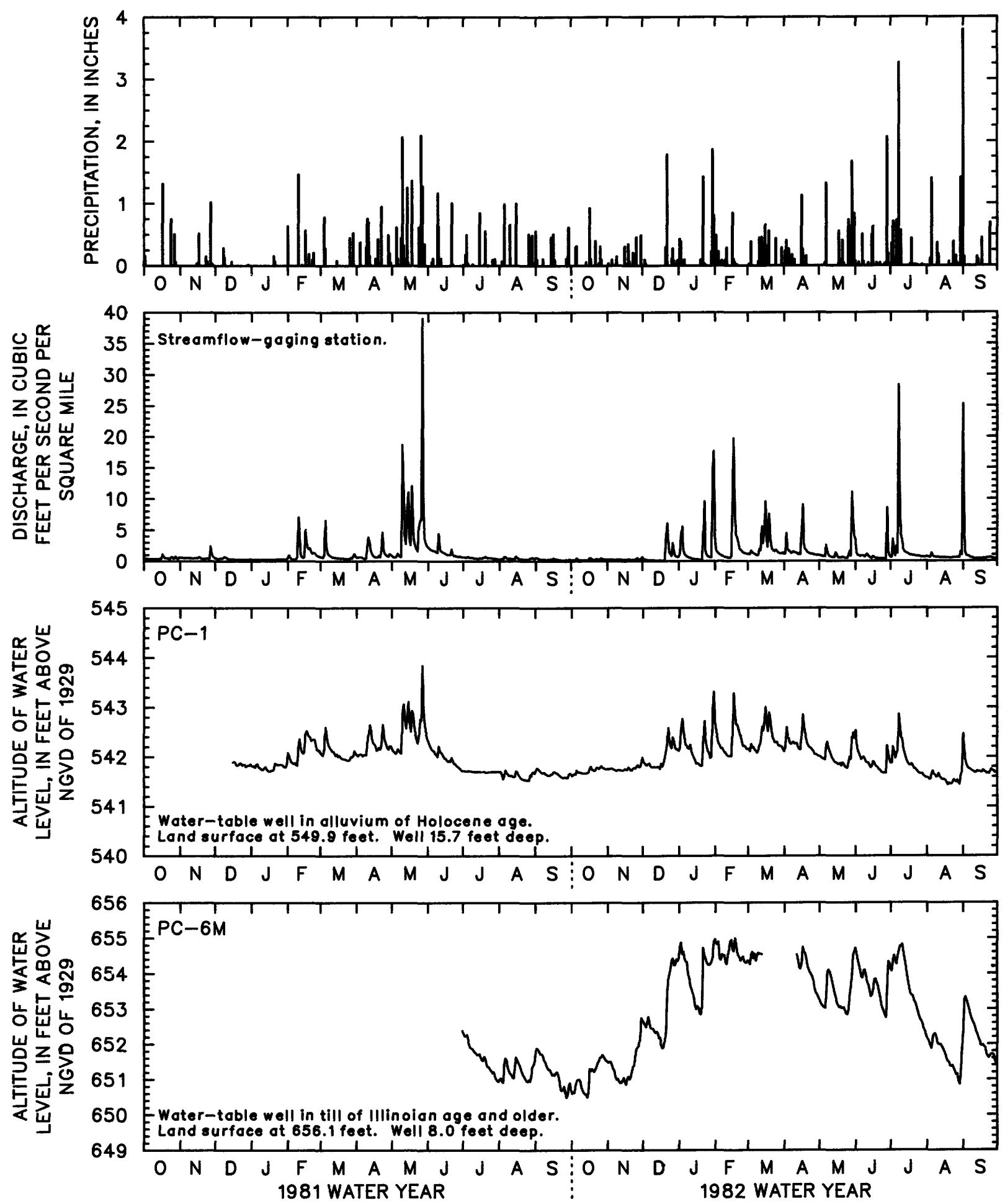

Figure 29. Daily precipitation and daily mean discharge and ground-water levels at Pond Creek, 1981 and 1982 water years. Interruption in water-level data indicates no data available. 

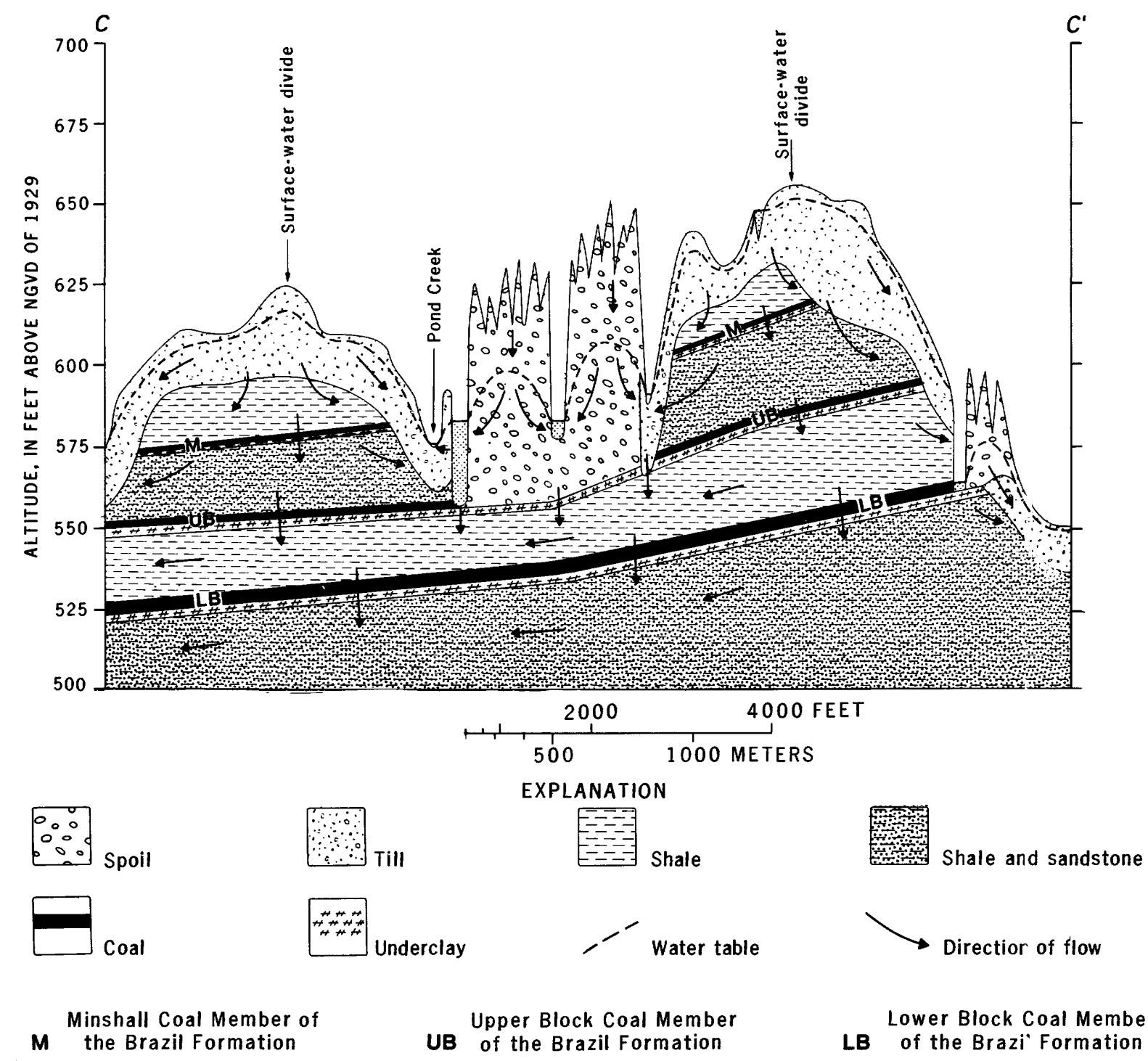
Upper Block Coal Member UB of the Brazil Formation
Lower Block Coal Member LB of the Brazi Formation

Figure 28. Hydrogeologic section showing generalized stratigraphy and direction of ground-water fiow at Pond Creek. Location of section $C_{-} C^{\prime}$ shown in figure 27.

The same characteristics that created local flow systems also created surface- and ground-water drainage basins that do not coincide in the vicinity of well MU-1. Shallow ground water from the small recharge lake southwest of well MU-1 flows beneath the surface-water divide toward the gage and contributes to perennial flow in Big Branch tributary. The surface- and ground-water divides probably do not coincide near the northeastern surface-water divide. Lakes immediately outside of the watershed are 20 to $40 \mathrm{ft}$ above the large lake that forms the main channel of Big Branch tributary (fig. 30). Ground water probably flows into the watershed from these lakes that are beyond the surface-water divide.

Water in the shallow bedrock flows southwestward along the structural dip of the rocks to areas of discharge about $3 \mathrm{mi}$ away along Busseron Creek (fig. 1). Water in the shallow bedrock does not discharge in the vicinity of the watershed because the surface of the bedrock beneath the spoil is relatively flat and no streams or lakes cut into the bedrock. Water in the deeper bedrock follow: the structural dip of the rocks to discharge areas about $15 \mathrm{mi}$ away along the Wabash River. 

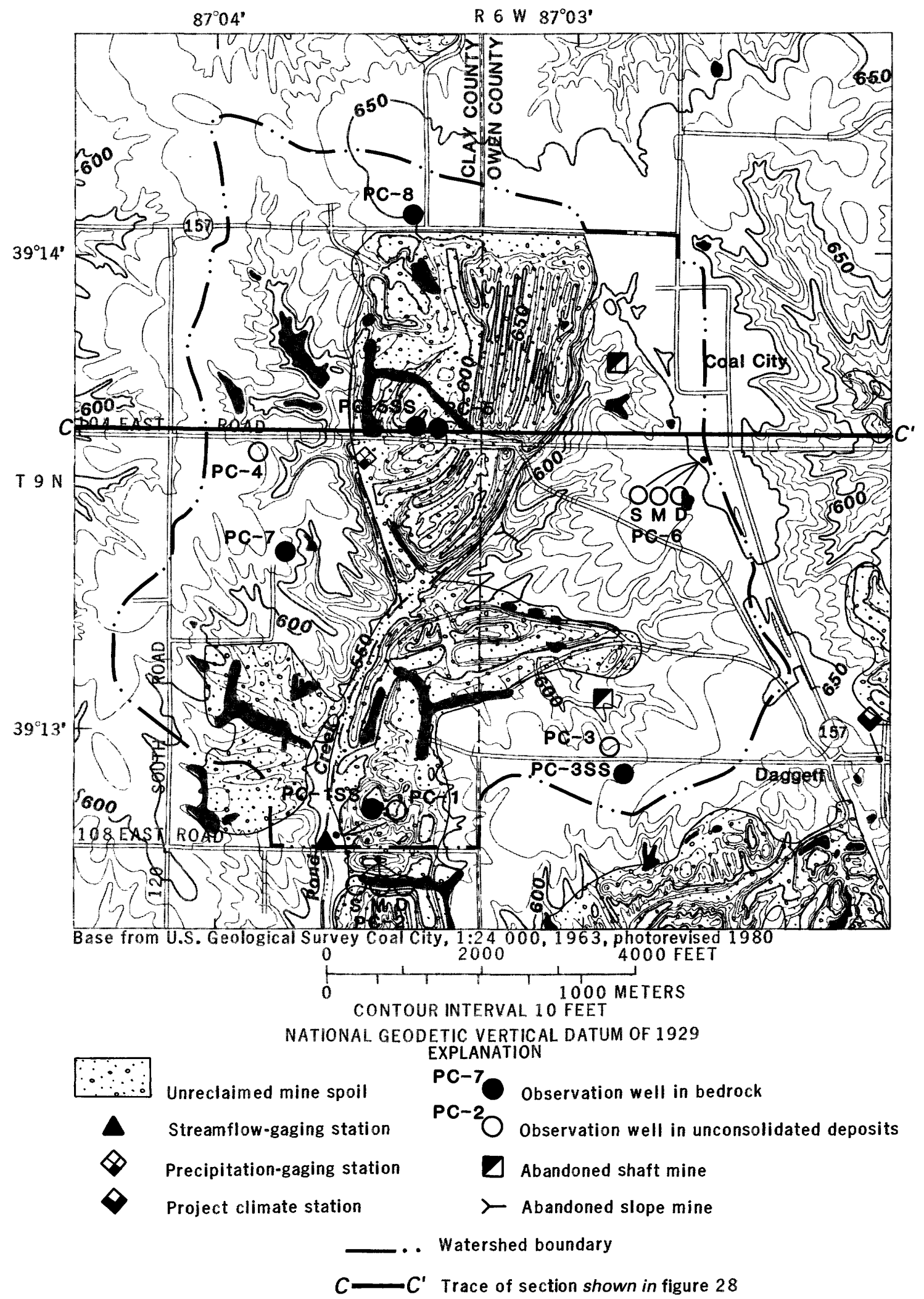

Figure 27. Pond Creek watershed and data-collection sites. 


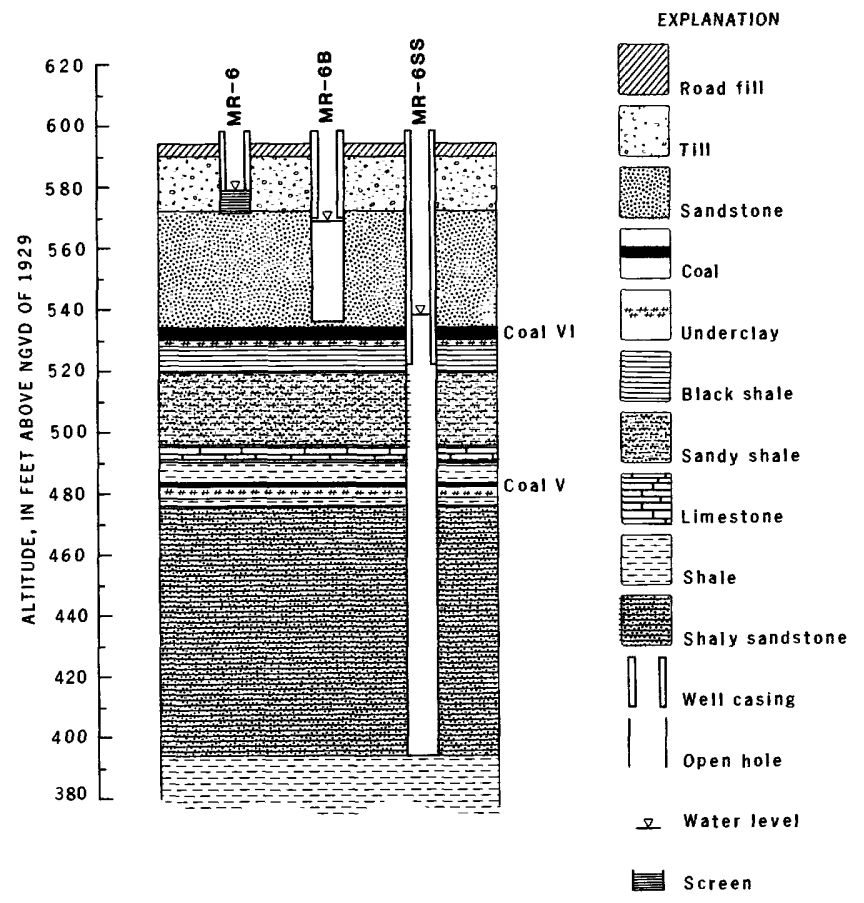

Figure 26. Geologic column showing distribution of water levels in well screened in till $(M R-6)$, well open to the Dugger Formation (MR-6B), and well open to the Dugger and Petersburg Formations (MR-6SS) at unnamed tributary to Sulphur Creek, September 7, 1982.

the gage and well PC-1 are closely related (fig. 29). Water levels in well PC-1 were generally 1 to $2 \mathrm{ft}$ above stream levels and indicate discharge of shallow ground water to Pond Creek. Water levels in all of the wells finished in unconsolidated deposits were above the elevation of Pond Creek.

Hydrographs of wells PC -1 and PC- $6 \mathrm{M}$ illustrate the seasonal pattern of recharge to the unconsolidated deposits (fig. 29). The uplands are recharged by infiltration of precipitation through till. In the center of the watershed, recharge occurs by infiltration of precipitation through spoil and by seepage of water that has collected in depressions above the water table. Water in the till discharges to Pond Creek or flows into the spoil; water in the spoil discharges to Pond Creek or to lakes in the spoil. Some of the water in the unconsolidated deposits and lakes moves downward to recharge the shallow bedrock (fig. 28).

Water in the wells finished in bedrock is confined by underclay or shale. Water levels in the bedrock fluctuated from less than 1 to $4 \mathrm{ft}$, and the amount of fluctuation was not associated with the depth of the formation. The bedrock is recharged by the downward movement of water in till, spoil, and lakes. Water in the shallow bedrock moves laterally to discharge areas near streams and mines, but some water moves downward to deeper bedrock aquifers (fig. 28). Water in the deeper bedrock aquifers flows southwest, approximately $5 \mathrm{mi}$, to areas of discharge along the Eel River (fig. 1).

\section{Unnamed Tributary to Big Branch}

One well was drilled in the Big Branch tributary watershed. This well (MU-1) is screened in unreclaimed mine spoil just above underclay and black shale bedrock. The well is between the lake that contains the gage at the mouth of the watershed and an impoundment outside of the surface drainage divide that is about $20 \mathrm{ft}$ higher in altitude (fig. 30). Hydraulic conductivity estimated for spoil near this well is $2 \times 10^{-2} \mathrm{ft} / \mathrm{d}$ (table 6). The Dugger and Petersburg Formations underlie the spoil and are composed of shale, sandstone, coal, and underclay (Mart'n and others, 1990, fig. 24, p. A36).

Well MU-1 is a flowing artesian well (fig. 31) where artesian conditions are controlled by topograrhy. The small impoundment approximately $200 \mathrm{ft}$ southwest of well MU-1 is at a higher altitude than the well and serves as a recharge area. The well is downgradient $o^{f}$ the recharge area and is screened at a depth were the wator level is less than 1 to $4 \mathrm{ft}$ above land surface. An example of a flowing artesian well that is topographically controlled is given in Freeze and Cherry (1979, p. 199).

Peak water levels in well MU-1 correlated with large precipitation events and peak water levels in the lake containing the gaging station (fig. 31). Peak water levels were not as well correlated from August to December 1981, when precipitation events were smaller. W'ater levels in well MU-1 fluctuated about $3.5 \mathrm{ft}$, wherees those at the gage fluctuated only about $1 \mathrm{ft}$. The difference in fluctuation and response to precipitation suggests that the surfacewater-ground-water interaction may be greater between well MU-1 and the lake that serves as the recharge area than between well MU-1 and the lake that serves as the discharge area and contains the gage. Additional evidence of greater interaction between well MU-1 ard the recharge lake is provided by the construction of a V-notch weir on the discharge lake from April 24 to May 8, 1981. Water levels in the discharge lake rose by about $2 \mathrm{ft}$, but water levels in well MU-1 did not show an associated rise after construction of the weir (fig. 31).

The shallow ground-water flow system in Big Branch tributary is composed of numerous local flov' systems. The local flow systems are created by the steep ridge-and-swale topography and multiple lakes and impoun-ments in and near the watershed. Recharge is by infiltration of precipitation through spoil or by percolation of water that has collected in depressions or impoundments above the water table. Impoundments at high elevations in $\mathrm{tl} \odot$ spoil are the major recharge areas. Impoundments at low elevations, such as the one containing the gage, are the major discharge areas. Some of the water in the spoil and c'eep lakes may move downward through the underclay and recharge the shallow bedrock. 

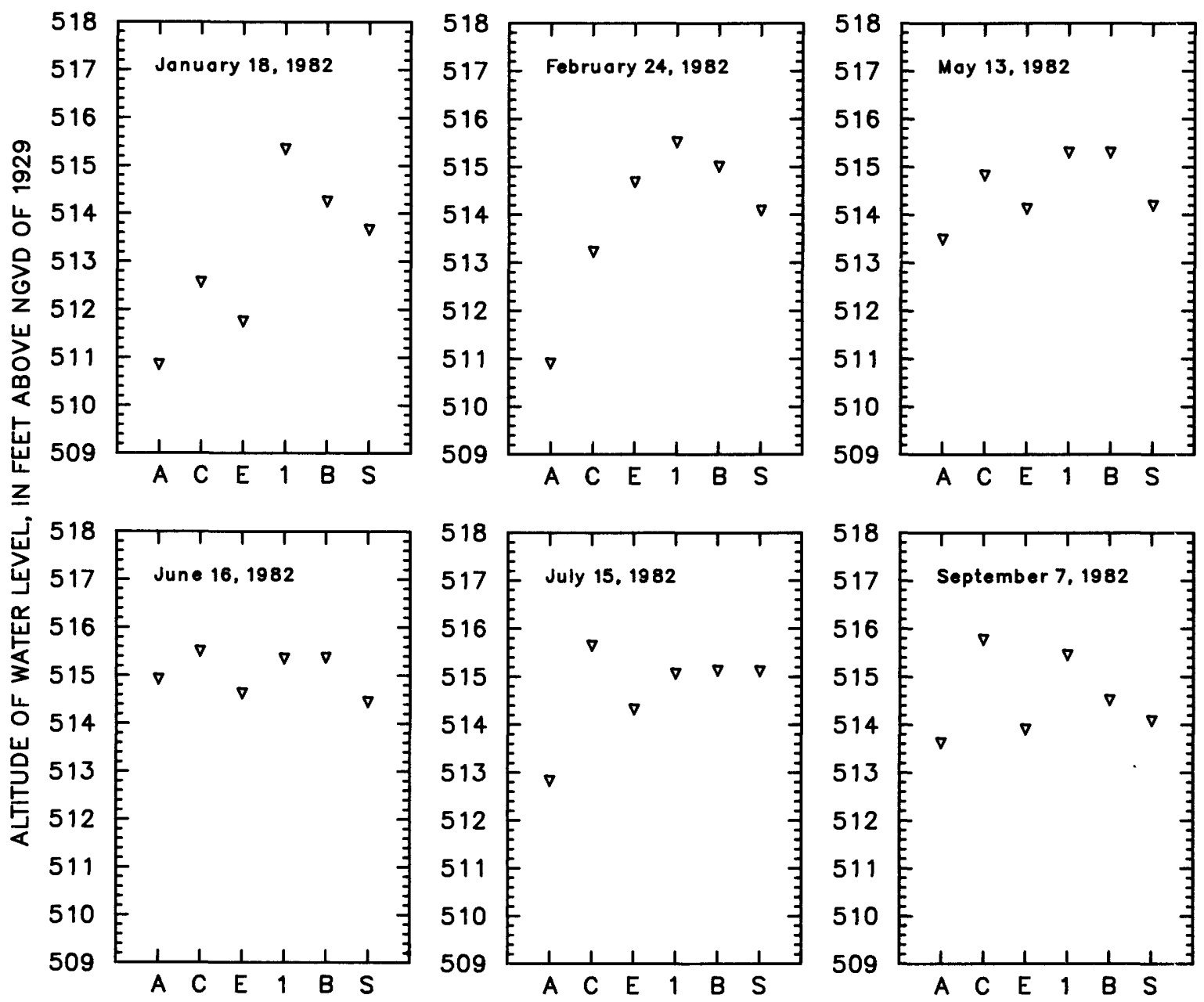

\title{
EXPLANATION
}

\begin{abstract}
A - Well MR-1A, 9.2 feet deep, land surface at 518.4 feet above NGVD of 1929.
C - Well MR-1C, 19.0 feet deep, land surface at 518.6 feet above NGVD of 1929.

E - Well MR-1E, 23.4 feet deep, land surface at 518.6 feet above NGVD of 1929.

1 - Well MR-1, 27.8 feet deep, land surface at 517.0 feet above NGVD of 1929.

B - Well MR-1B, 43.8 feet deep, land surface at 518.5 feet above NGVD of 1929.

S - Well MR-1SS, 101.1 feet deep, land surface at 518.6 feet above NGVD of 1929.
\end{abstract}

Figure 25. Distributions of water levels in nest of wells finished in reclaimed mine spoil or bedrock at unnamed tributary to Sulphur Creek. Wells MR-1A, MR-1B, MR-1C, and MR-1E are finished in spoil, have 2-ft screens, and are cased to land surface. Well MR-1 is finished in spoil, has a $5-\mathrm{ft}$

confined conditions near well $\mathrm{PC}-6 \mathrm{D}$ or from a layer of more permeable till near well $\mathrm{PC}-6 \mathrm{M}$ that is connected hydrologically to a discharge area. Complexities in the flow system at small scales illustrate the importance of structure, composition, and hydraulic properties of the glacial deposits. Although the general direction of flow may be lateral screen, and is cased to land surface. Well MR-1 1 S is finished in bedrock, predominantly shale, ard has $53 \mathrm{ft}$ of casing and $48 \mathrm{ft}$ of open hole. Altituc's of the water level in the final-cut lake ranged from 518.1 to $518.4 \mathrm{ft}$ above NGVD of 1929 on the dates presented in the graphs. 

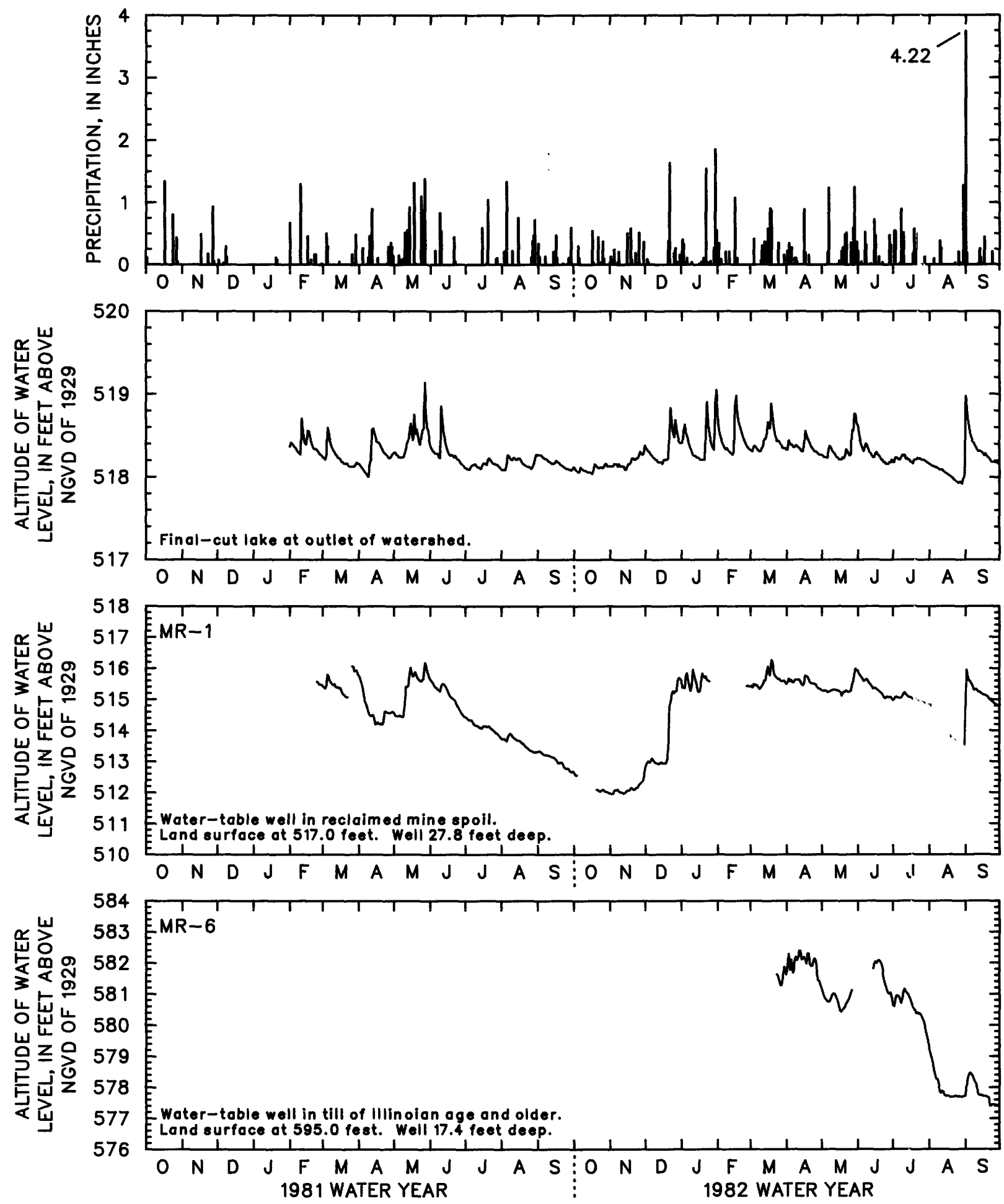

Figure 24. Daily precipitation and daily mean lake and ground-water levels at unnamed tributary to Sulphur Creek, 1981 and 1982 water years. Interruption in water-level data indicates no data available.

suggest confined conditions and an upward component of flow at depth.

Water levels in the nest of wells finished in till show a different pattern of head loss. Wells PC-6S, PC-6M, and
PC-6D are 6,8 , and $10 \mathrm{ft}$ deep, respectively, and have $2-\mathrm{ft}$ screens. Water levels in well PC-6S wer? generally the highest, whereas water levels in well PC- $6 \mathrm{M}$ were generally the lowest. This pattern of head loss can result from 


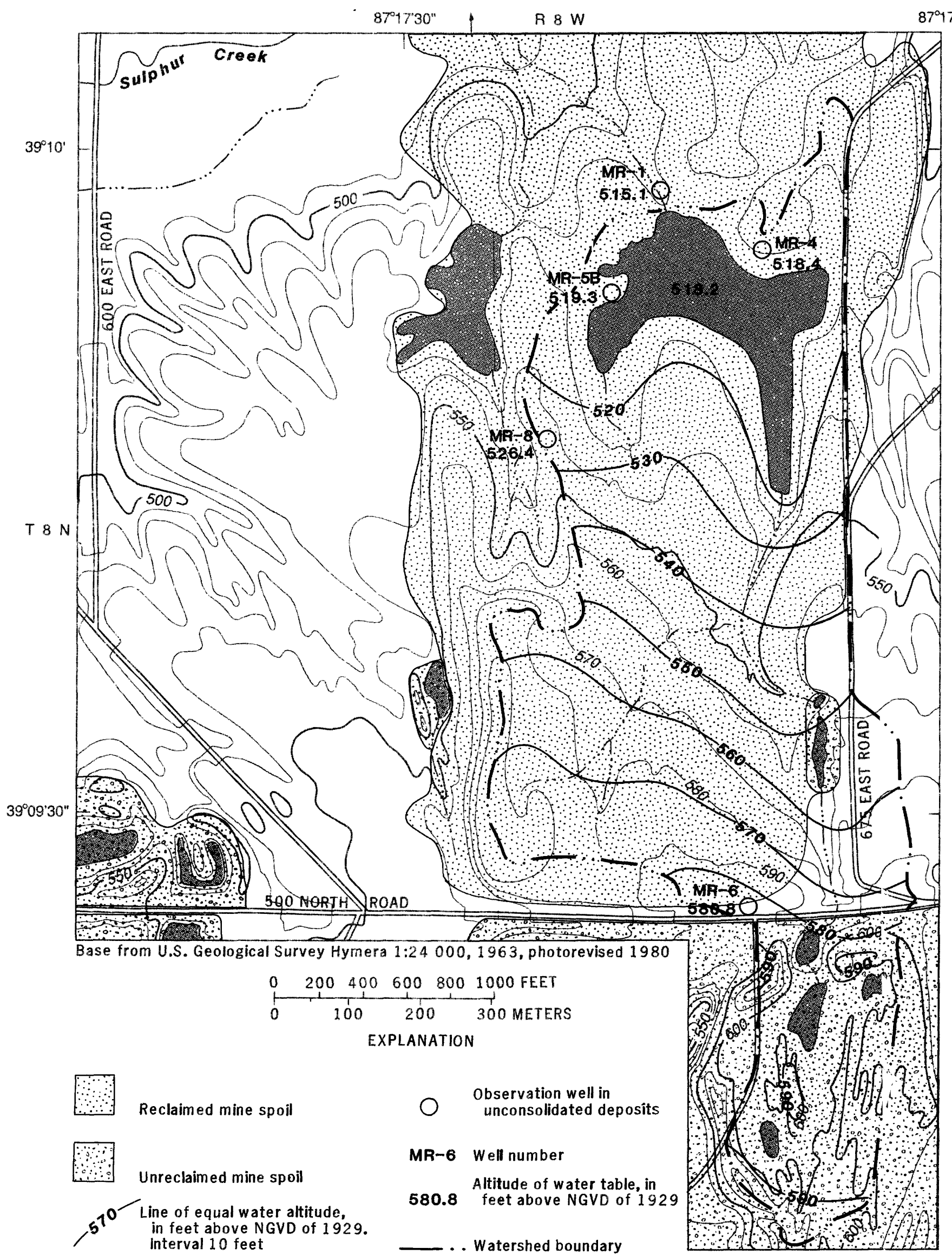

Figure 23. Altitude of water table at unnamed tributary to Sulphur Creek, July 15, 1982. 


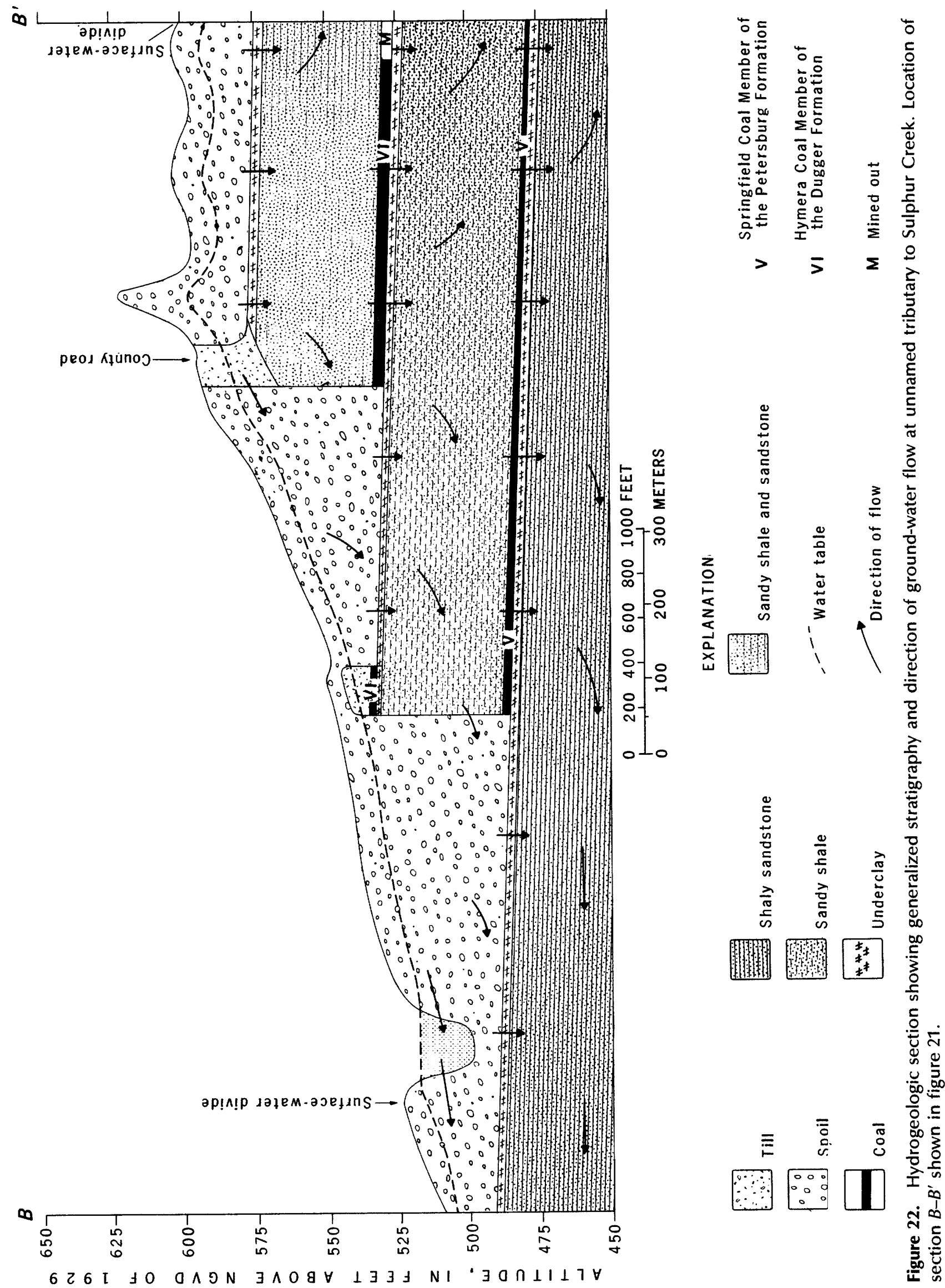


smaller amounts of coal, underclay, and limestone. Eleven wells were installed in mine spoil, one well in till, and six wells in bedrock (fig. 21).

The water table in the spoil is generally about $10 \mathrm{ft}$ below land surface, but because of areas of high relief and the effect of impounded water, depths to water vary from less than 1 to $25 \mathrm{ft}$ (fig. 22). Shallow ground water flows from the headwaters toward a lake. Flow in the vicinity of the lake is mostly toward the lake except near the outlet, where flow is to the north (fig. 23). Ground-water inflow results in sustained surface-water flow in Sulphur Creek tributary in all but a few months of the year.

Water levels in wells finished in spoil fluctuate from 2 to $6 \mathrm{ft}$. Water levels in at least one well near the lake (MR-1) correlate well with lake levels and indicate good hydraulic connection between the surface-water system and the ground-water system (fig. 24). The degree of surfacewater-ground-water interaction in the vicinity of the other wells cannot be readily determined from intermittent ground-water measurements. Interaction is probably good where wells are finished in zones of high hydraulic conductivity and is probably poor in zones of low hydraulic conductivity.

A nest of seven wells was installed at different depths in the spoil to determine flow patterns near the lake (fig. 21). One well, well MR-1D (14.0 ft deep), appeared to have a plugged screen and was not used in the analysis. The pattern of head loss in the nest of wells does not show a predominant direction of movement but usually shows higher heads in the middle of the spoil than near the surface or the bottom of the spoil (fig. 25). Lack of a consistent pattern of head loss probably reflects the great variability of hydraulic conductivity of the spoil and (or) hydrologic connection with the lake or the discharge area. Differing degrees of hydraulic conductivity and hydrologic connection result in a flow system near the lake that is likely composed of many small, relatively isolated flow systems that follow torturous flow paths. Water levels in well MR-1B (finished in spoil just above the underclay at the base of the spoil) are consistently above those in well MR-1SS (open to bedrock below the underclay). This difference indicates a downward component of flow from the spoil to the bedrock. The pattern of water levels in all six wells is not consistent for the six dates of measurement and is not clearly associated with precipitation events (figs. 24,25 ).

Water-level fluctuations show a seasonal pattern typical of ground-water recharge in Indiana. Most of the recharge follows periods of snowmelt or prolonged precipitation during winter and spring when vegetation is dormant (fig. 24). The spoil is recharged by infiltration of precipitation and by infiltration of water in impoundments and depressions. Shallow ground water moves toward the finalcut lake, where some water is discharged. Water in the lake reenters the spoil to the north and flows north to points of discharge along Sulphur Creek. Some water in the spoil moves downward into the bedrock (fig. 22).

Hydraulic conductivity of five wells open to the Dugger, Petersburg, and (or) Linton Formations ranged from $2 \times 10^{-4}$ to $4 \times 10^{-2} \mathrm{ft} / \mathrm{d}$ (table 6 ). Water-level fluctuations in the bedrock ranged from 2.6 to $4.9 \mathrm{ft}$ and decreased in the deeper formations. Water leve's in two wells finished in bedrock (MR-6B and MR-6SS) and one well finished in till (MR-6) near the southern part of the watershed show decreasing water-level elevations with depth and indicate a downward component of flow (fig. 26). Shallow ground water in the sandstone tappet by well MR-6B was unconfined. Water in the other bedrock wells was confined by underclay or by underclay and shale.

Water in the bedrock beneath much of Sulpl "ur Creek tributary follows a local flow path to points of discharge at a final-cut lake approximately $1,000 \mathrm{ft}$ north of the watershed. This final-cut lake forms the channel of Sulphur Creek and is at a much lower elevation than the water levels in the bedrock at Sulphur Creek tributary. Wator in the bedrock beneath the headwaters of Sulphur Creek tributary probably is part of a regional flow system that fo'lows the southwest structural dip and discharges along the Wabash River (fig. 1).

\section{Pond Creek}

Fifteen wells were installed in or near the Pond Creek watershed. Analysis of the well logs showed 10 to $25 \mathrm{ft}$ of sandy clay till near the edges of the watershed and about 65 $\mathrm{ft}$ of unreclaimed mine spoil near the center (Martin and others, 1990, fig. 22, p. A33). These uncorsolidated deposits are underlain by sandstone, shale, coal, and underclay of the Brazil Formation. Beneath th Brazil Formation are sandstone and shale of the Mansfielt Formation. Six observation wells were finished in bedrcck, three in coal-mine spoil, five in till, and one in alluvium (fig. 27).

Till in the uplands of the Pond Creek watershed can have greater hydraulic conductivity than spoil or bedrock. Hydraulic conductivities estimated from slug test: at three wells in till ranged from $7 \times 10^{-3}$ to $9 \times 10^{-1} \mathrm{ft} / \mathrm{d}$ (table 6). Hydraulic conductivities at three wells in spoil ranged from $1 \times 10^{-3}$ to $6 \times 10^{-2} \mathrm{ft} / \mathrm{d}$, whereas hydraulic conductivities at three bedrock wells open to the Brazil and (or) Mansfield Formations ranged from $5 \times 10^{-3}$ to $2 \times 10^{-1} \mathrm{ft} / \mathrm{d}$ (table 6).

Water levels in wells finished in till fluctuated 2 to 6 $\mathrm{ft}$, whereas the water level in the well finished in alluvium fluctuated about $2 \mathrm{ft}$. Fluctuations of the water levels in wells PC-2S and PC-2M (the shallow and medium wells in the nest of wells finished in spoil) were less than $1 \mathrm{ft}$, whereas fluctuation in well PC-2D (the deep well) was greater than $3 \mathrm{ft}$. Water levels in well $\mathrm{PC}-2 \mathrm{~S}$ were slightly higher than those in well PC-2M; this small difference in water levels indicates predominantly horizontal flow in this part of the spoil. Water levels in well PC-2D were 4 to $6 \mathrm{ft}$ higher than those in shallower wells; the higher levels 


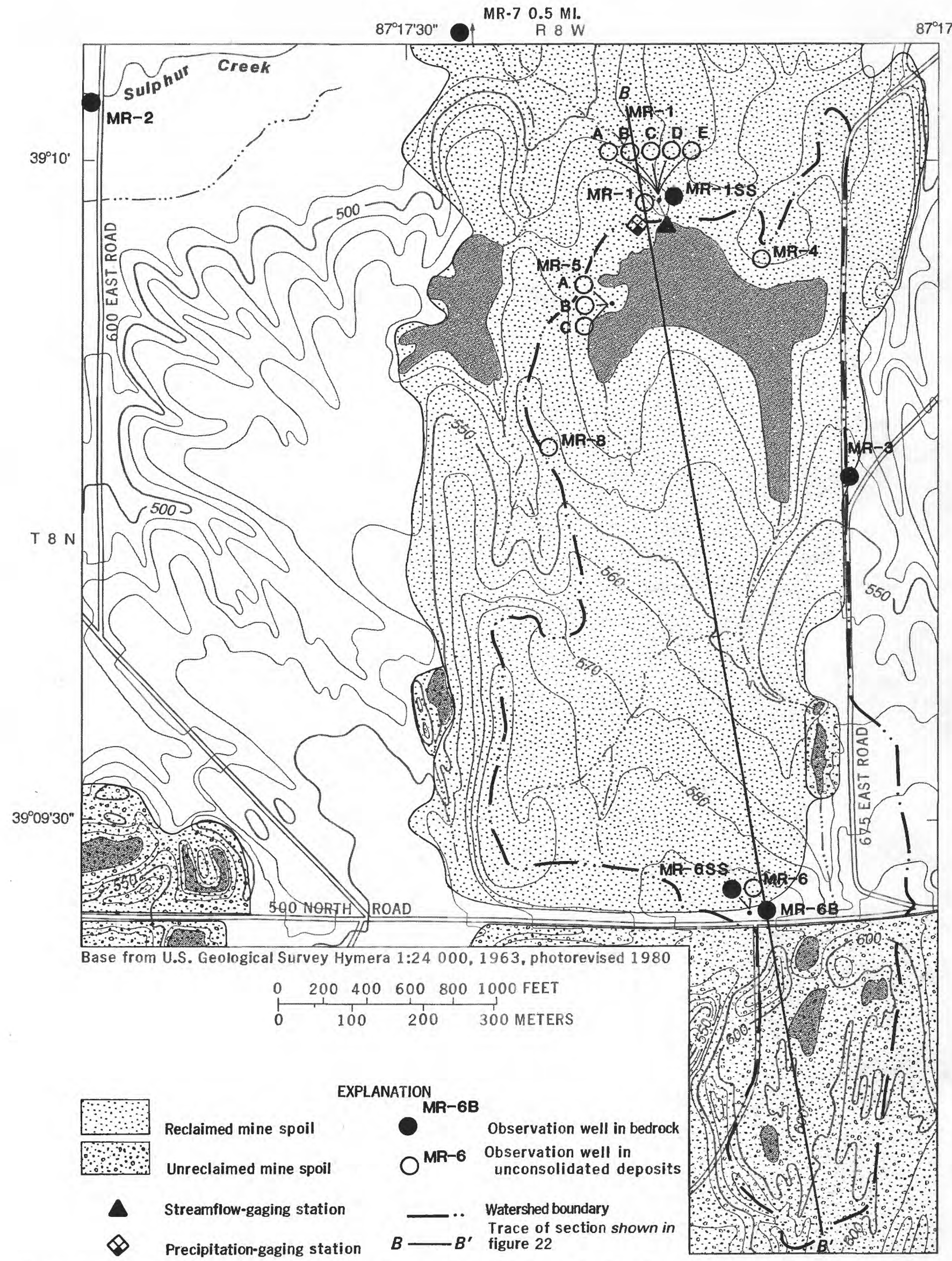

Figure 21. Unnamed tributary to Sulphur Creek watershed and data-collection sites.

B34 Physical Environment and Geohydrologic Effects of Surface Coal Mining in West-Central Indiana 

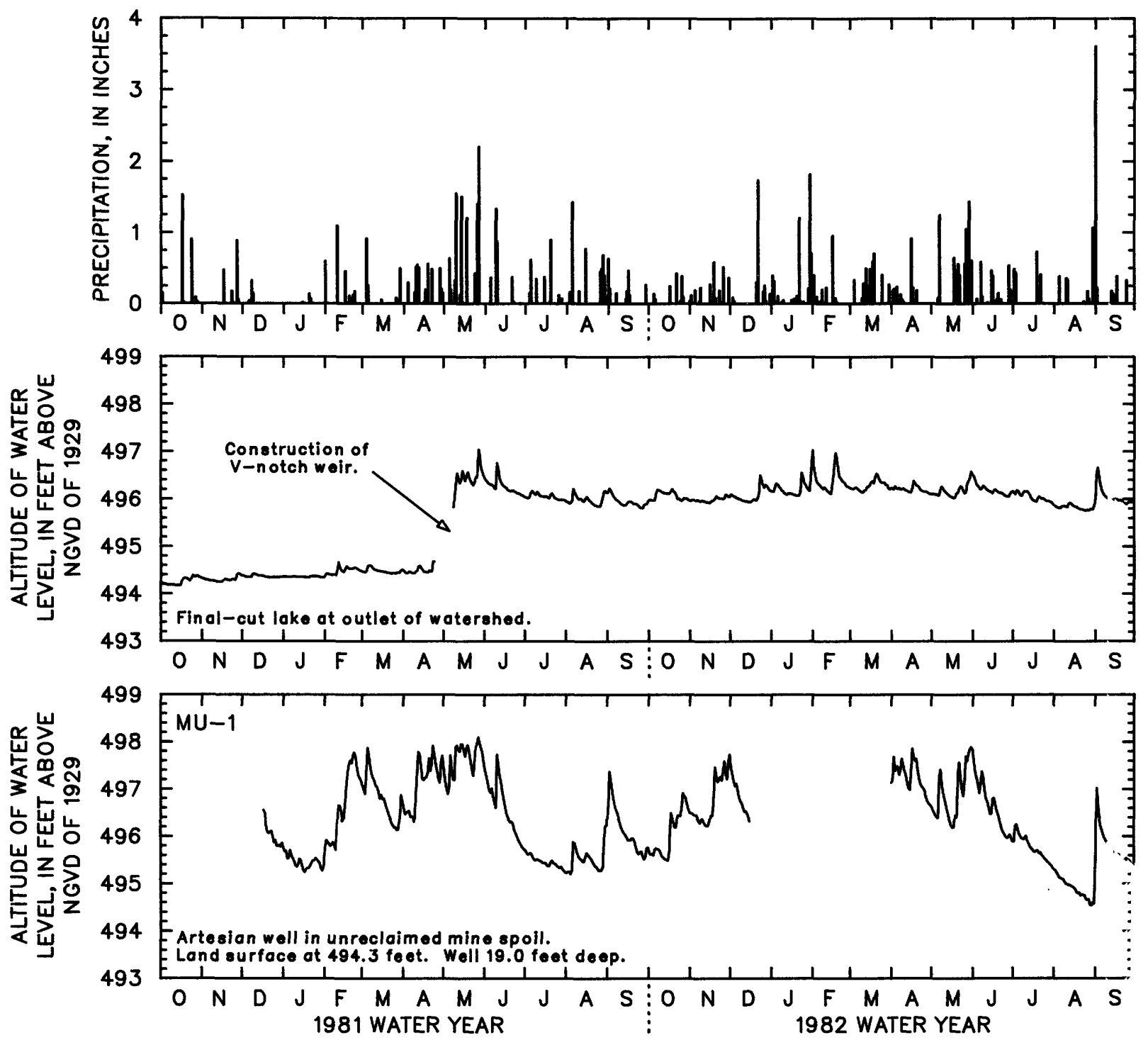

Figure 31. Daily precipitation and daily mean lake and ground-water levels at unnamed tributary to Big Bran-h, 1981 and 1982 water years. Interruption in water-level data indicates no data available.

\section{EFFECTS OF SURFACE COAL MINING AND RECLAMATION ON THE GEOHYDROLOGY OF SMALL WATERSHEDS IN WEST-CENTRAL INDIANA}

Hydrologic effects of surface coal mining and reclamation can be determined by study of watershed hydrology before mining began, during mining, and after reclamation (Curtis, 1973; Emerson, 1981; U.S. Department of Agriculture, Agricultural Research Service and Ohio State University, 1983; Weiss and Razem, 1984); by comparison of nearby mined and unmined watersheds (Corbett, 1965; Collier and others, 1970; Grubb and Ryder, 1972; Zogorski and others, 1981; Brabets, 1984); or by simulation (Wilson and Hamilton, 1978; Meadows and Blandford, 1983; Scott,
1984). For this study, effects of surface coal mining were identified by comparing hydrologic characteristics of mined and unreclaimed watersheds with those of unmined agricultural watersheds (Big Slough and Hooker Creek). Effects of reclamation were identified by comparing mined and reclaimed watersheds (Honey Creek tributary and Sulphur Creek tributary) with mined and unreclaimed watersheds (Pond Creek and Big Branch tributary). The overall effects of mining and reclamation were identified by comparing mined and reclaimed watersheds with unmined agricultural watersheds.

The success of a comparative approach re-ts on a basic assumption - that surface- and ground-water systems at mined watersheds would have been similar to those at unmined agricultural watersheds if surface mining had not occurred. This assumption is probably valid for these six 
watersheds because (1) all are small, upland watersheds in a region of similar soils, geology, and geomorphology; (2) all are within a 12-mi radius and are exposed to similar weather conditions; and (3) row-crop agriculture is the major land use in the region and probably was the major premining land use in the mined watersheds.

The surface- and ground-water systems at Big Slough and Hooker Creek are similar and are representative of the hydrologic systems at the other watersheds before mining. The unmined agricultural watersheds have well-developed, integrated drainage systems, and ground-water divides generally coincide with surface-water divides. Streamflow in both agricultural watersheds is highly variable and has similar magnitudes and patterns of low and high flows (figs. $6 A, B, 7$ and table 2). Both Big Slough and Hooker Creek respond rapidly to thunderstorms and have high peak flows (tables 4, 5 and fig. 9). Both agricultural watersheds have similar total runoff and similar distributions and amounts of monthly runoff (table 3 and fig. 8). Shallow ground water at both watersheds is recharged by precipitation through till in the uplands between streams and is predominantly discharged to streams that cut into the till.

Another assumption is often made when comparing watersheds to determine effects of mining and reclamation. The assumption that unreclaimed watersheds have similar hydrologic systems and that reclaimed watersheds have similar systems is tenuous and often incorrect. For example, both Honey Creek tributary and Sulphur Creek tributary are reclaimed watersheds. However, the gage at Honey Creek tributary is immediately upstream of a final-cut lake, whereas the gage at Sulphur Creek tributary is at the outlet of a final-cut lake. Clearly the hydrologic characteristics of these watersheds, as measured by the gages, are different. The hydrologic effects of mining and reclamation identified by comparing watersheds in this study must be viewed in relation to differences between Honey Creek tributary and Sulphur Creek tributary and to differences between Pond Creek and Big Branch tributary. Moreover, the hydrologic effects identified at these four watersheds must be considered potential effects of mining and reclamation at other watersheds. Extrapolation of the results of this study to other areas must be done with caution and judgment.

Hydrologic effects of surface mining and reclamation are discussed in sections relating to physical characteristics of the watersheds and various components of the hydrologic cycle. Discussion may be repetitive because of interactions and interdependencies of characteristics and components.

\section{Watershed Morphology, Surface Runoff, and Detention Storage}

Surface coal mining creates watersheds that have complex morphologic features that are drastically different than those of unmined watersheds. Spoil created by mining at Pond Creek and Big Branch tributary wa deposited in bands or banks having high relief, narrow ridres, and steep slopes. As mining progressed, new spoil bant-s were placed next to old spoil banks; this system of banks formed a ridge-and-swale topography that contained numerous depressions and impoundments of water. $A$ complicated pattern of spoil banks and depressions was created when the direction of mining changed or when roads used to haul coal were moved. Deep, final-cut lakes were created when mining ceased and the open pits filled with water. The diverse topography of Pond Creek and Big Branch tributary is characterized by complex, discontinuous drainage systems that have many areas enclosed by spoil banks incapable of contributing surface runoff to streams (figs. 27, 30). Parts of the surface drainage systems include depressions or lakes instead of stream channels and incluce water-filled impoundments that contribute to surface runoff only at high stages.

The capacity of the Pond Creek watershed and the Big Branch tributary watershed to delay or store surface runoff has been greatly increased by surface mining. Water stored in the numerous depressions, impoundments, and lakes can be prevented from contributing to surface runoff or can be slowly released. Water held in depressions above the water table recharges the ground water. The hydrologic effects of mining have been to (1) increase base flow and create perennial flow from these unreclaimed watersheds (fig. 7 and table 2), (2) increase the total runoff (table 3), (3) reduce peak flows and variation in flows (fig. 7 and table 4), (4) decrease monthly runoff during w'et months and increase runoff during dry months (fig. 8), (5) lengthen watershed response times to thunderstorms (table 5 and fig. 9), (6) change the relation of surface- and ground-water divides, thus resulting in ground-water inflow from adjacent watersheds (at Big Branch tributary), (7) crecte more local, shallow ground-water flow systems, (8) lower the water table in upland areas not influenced by water impoundments, and (9) increase recharge to the ground'-water system in the bedrock. Pond Creek has higher peak flows and quicker watershed response than Big Branch tributary because the gage at Pond Creek is on a stream channel, whereas the gage at Big Branch tributary is at the outlet of a lake. Additionally, all of Big Branch tributary has been mined, but only about 40 percent of Pond Creek has been mined.

The primary objective of reclamation is to change the topography, hydrology, soils, and vegetation of recently mined land to those that will be most benoficial for the intended postmining land use. Common postmining land uses in Indiana are pasture, hay, row-cron agriculture, wildlife habitat, forest, and recreation. The intended postmining land uses for Honey Creek tributary and Sulphur Creek tributary are not known but are probably pasture or hay. Activities used to reclaim these watersheds included (1) grading the spoil to a level or gently undulating 
topography that minimizes depressions and approximates the premining topography and drainage system, (2) replacing 6 to 12 in. of soil over graded spoil, (3) seeding and fertilizing grasses and legumes to achieve a vegetative cover, and (4) mulching and other practices to control erosion. The final cuts were allowed to fill with water.

The principal effects of reclamation on the morphology of Honey Creek tributary and Sulphur Creek tributary were to eliminate the ridge-and- swale topography of unreclaimed mines and to make the surface drainage systems simpler and more continuous. Reclamation at Sulphur Creek tributary has removed nearly all of the depressions and water impoundments created by mining, except for the final-cut lake and the unreclaimed area in the headwaters. The surface drainage system can be identified easily, and all reclaimed areas contribute to surface runoff. The capacity of the mined land to store surface runoff by detention storage has been reduced, although substantial capacity still exists because of the final-cut lake, two impoundments located along the stream, and several impoundments in the headwaters (fig. 21).

The capacity to store surface runoff at Honey Creek tributary also has been reduced by reclamation. However, the capacity is still much greater than it would have been if not for impoundments created for livestock and by building a road. Approximately 15 percent of the watershed drains into the livestock impoundment and does not contribute to surface runoff. Approximately 42 percent of the watershed (not including the drainage area of the livestock pond) drains into an impoundment created by the road (fig. 17). This impoundment can hold approximately 0.33 acre-ft (acre-feet) of water (the volume of water from 0.15 in. of precipitation, assuming an impervious surface) before flow through a culvert will occur. Although the detention storage capacity of the reclaimed watersheds is much less than that of the unreclaimed watersheds, it is much greater than that of the agricultural watersheds.

The hydrologic effects of reclamation differed between the reclaimed watersheds, probably because of the effect of the final-cut lake at Sulphur Creek tributary. The final-cut lake at Sulphur Creek tributary serves as the mouth of the watershed and has a gage at the outlet (fig. 21), whereas the final-cut lake at Honey Creek tributary is immediately downstream from the gage (fig. 17). The hydrologic effects of reclamation at Sulphur Creek tributary were to make discharge intermittent and more variable and to decrease the total amount of runoff (fig. 7 and tables 2, 3 ). The increase in flow variation and no flow was probably caused by the elimination of depressions (which previously enhanced ground-water recharge that sustained streamflow) and the reconstructed drainage system. Peak discharges increased (table 4), probably because surface runoff reached the final-cut lake much more rapidly than at unreclaimed watersheds and opportunity for ground-water recharge was diminished.
Reclamation at Honey Creek tributary hes made discharge ephemeral and therefore highly variahle and responsive to thunderstorms (figs. 7, 9). Peak discharge and the number of no-flow days have increased in reclaimed watersheds in comparison to unreclaimed watersheds (tables 2, 4). Ephemeral discharge also results in th: lowest annual runoff at Honey Creek tributary (table 3). "The lack of base flow at Honey Creek tributary is caused primarily by the topographic relation of the stream channel and the final-cut lake but is caused partly by the elimination of water bodies in the watershed that had provided detention storage and opportunity for ground-water recharge.

Some of the overall effects of mining and reclamation on watershed morphology, surface runoff, and detention storage also were influenced by the final-cut lake in the Sulphur Creek tributary watershed. Annual runoff at the reclaimed watersheds was less than that at the agricultural watersheds (table 3 ), but the monthly distribution $c^{f}$ runoff was not noticeably different between reclaimed and unmined watersheds (fig. 8). At Sulphur Creek tributary, the duration and magnitude of base flows and flow variation have not been noticeably affected (figs. 7, 8 and table 2), but peak flows have been reduced, and the response time of the watershed to thunderstorms has been lengthened (tables 4, 5). At Honey Creek tributary, peak flows and the response time of the watershed to thunderstorms lave not been noticeably affected, but the magnitude and duration of base flow have decreased, and flow has become more variable. Elimination of detention storage provided by the water impoundments created for livestock and by the haul road probably would increase peak discharge to a magnitude comparable to or greater than that at the unmined, agricultural watersheds.

\section{Soils, Vegetation, Infiltration, and Evapotranspiration}

Soils, vegetation, and the processes of infiltration and evapotranspiration are components of a complex hy drologic system that controls the movement and distribution of water. Each of these components influences and is influenced by the others through feedback mechanisms typical of hydrologic systems. Infiltration is the process whereby water at land surface enters the soil. Soil water-holding capacity, soil texture and structure, and surface conditions are characteristics of the soil that influence infiltration. Evapotranspiration is the process that removes water from near the surface of the soil by evaporation and removes water in the rooting zone by transpiring vegetation. Soil moisture, soil water-holding capacity, and the type and extent of vegetation influence evapotranspiration.

Surface mining changes the soils and vegetation of agricultural lands in a variety of ways. Surface mining destroys soil structure and horizons by mixing the soil with 
till and fragments of bedrock. Spoil created by mining is classified as the Fairpoint soil series and generally has greater moist bulk density, slope, and large fragments but lower available water capacity and organic matter than soils in agricultural watersheds (McCarter, 1982, table 17, p. 145-147; Wells and others, 1983, table 1, p. 16). The permeability of the top 2 to $3 \mathrm{ft}$ of thoroughly wet Fairpoint soils is usually less than that of most agricultural soils (McCarter, 1982, table 17, p. 145-147). However, some agricultural soils in the study area have a fragipan or other impermeable layer at a depth of 2 to $3 \mathrm{ft}$ (Martin and others, 1990, table 10). The permeability of Fairpoint soils at this depth is usually greater than that of agricultural soils containing an impermeable layer but is usually less than or equal to that of agricultural soils lacking an impermeable layer.

Most of the land surface mined for coal in Indiana is agricultural land, either row crop, pasture, or hay. Vegetation characteristic of these land uses includes corn, soybeans, alfalfa, clover, grasses, and oaks and hickories in small woodlots. Surface mining results in a change of vegetation from agricultural crops to trees and other plants that can tolerate the harsh, inhospitable conditions of bare mine spoil. Typical tree species found on unreclaimed spoil include black locust, ash, silver maple, cottonwood, Virginia pine, and jack pine. Early-successional plants (including grasses, weeds, and trees) usually invade and recolonize most spoil banks, but many unreclaimed spoil banks are covered with trees planted by man. The extent of vegetative cover on unreclaimed mines varies greatly; at Pond Creek and Big Branch tributary, trees planted by man generally cover the spoil banks, but the surface of the spoil is usually bare.

Modern reclamation techniques require grading spoil to a rolling topography, replacement of topsoil, and seeding and mulching to produce vegetative cover and reduce erosion. Approximately 6 to 12 in. of topsoil was placed over graded spoil at Honey Creek tributary and Sulphur Creek tributary. The topsoil was distinguished from the underlying spoil by its brown color and relative absence of stones and boulders. The topsoil contained an extensive mass of fine to very fine roots, and some roots extended into the spoil (U.S. Soil Conservation Service, written commun., 1982). Grasses and legumes were sown and have developed in both watersheds. Vegetative cover is dense at Sulphur Creek tributary but is sparse at Honey Creek tributary.

Infiltration and evapotranspiration were not measured during this study. As a consequence, the effects of mining and reclamation on these components of the hydrologic cycle could not be directly evaluated. Indirect methods of evaluating infiltration and evapotranspiration (such as analysis of precipitation-runoff hydrographs and calculation of annual water loss) were hampered by the short period of record and different detention-storage characteristics and ground-water systems. Analysis of runoff cxefficients for the storm hydrographs (table 5) may indicate a smaller infiltration capacity at Hooker Creek than at Honey Creek tributary. However, differences in runoff coefficients more likely are influenced by detention storage, and inferences regarding infiltration are largely speculative.

Annual water loss (table 3 ) indicates that the combined effects of evapotranspiration and subsurface flow out of the watershed were greater at Honey Creek tributary than at the other watersheds. Recharge of water detained in impoundments and subsurface outflow or eve joration from impoundments are more likely causes of high water loss than high transpiration. Low water loss $\mathrm{a}^{+} \mathrm{Big}$ Branch tributary is probably caused by subsurface irflow of water from lakes outside of the watershed rather th?n by reduced evapotranspiration. Assuming that surface- and groundwater divides coincide and that ground-water flow beneath the gages is negligible, average annual evarotranspiration estimated from annual water loss for the 1981 and 1982 water years is about 26 to 27 in. for Big Slough, Hooker Creek, Sulphur Creek tributary, and Pond C ceek (table 3). Estimates of evapotranspiration at Honey Creek tributary and Big Branch tributary are more uncertain because of uncertainty about the amount of subsurface outflow or inflow.

\section{Ground-Water Systems}

Surface mining can change the relation between surface- and shallow ground-water divides, especially in watersheds that have been extensively mined. Shallow ground-water divides generally coincide with surface-water divides in the unmined agricultural watershe ts. The placement of spoil can create several small watersheds in the same location as the original, larger watershed. Groundwater basins can be larger than surface-water basins if the surface drainage systems created by mining are abruptly truncated by spoil banks or altered by haul roads. Groundwater basins can be smaller than surface-water basins if topography and surface-mine impoundments create numerous local, shallow ground-water flow cells.

Hydrologic effects caused by changing the size of the ground-water basin in relation to that of the surface-water basin are primarily a potential increase in both the magnitude and duration of base flow, if the ground-water basin is larger than the surface-water basin, or a potential decrease in base flow, if the ground-water basin is smaller. Increased base flow at Big Branch tributary has resulted from a larger ground-water basin, but base flow from this source is probably less important than that from ncmerous water impoundments within the watershed. The re'ation between surface- and shallow ground-water divides at Pond Creek does not appear to have been significantly affected by mining, probably because mining occurred near the center 
of the watershed. The ground-water divide may have moved outward if shallow ground-water flow to the mined area increased or inward if ground-water flow to the mined area decreased from premining conditions.

The effect of reclamation on the relation between surface-water and ground-water divides largely depends on the extent that grading eliminates depressions and produces surface-water divides that incorporate the local upland areas where ground-water divides occur. The mine that formed the Sulphur Creek tributary watershed was small, and much of the surrounding upland area is unmined. Grading has restored the approximate premining topography, and surface- and ground-water divides probably coincide. Duration and magnitude of base flow at Sulphur Creek tributary are similar to those at the agricultural watersheds (fig. 7 and table 2). The mine that formed the Honey Creek tributary watershed is much more extensive than the mine that formed the Sulphur Creek tributary watershed. Premining and postmining topography differ. Several small watersheds have been formed by grading the land to allow drainage into large impoundments. Much of the local upland areas is north of the surface-water divide. The ground-water basin at Honey Creek tributary is much larger than the surface-water basin, but because the surface- and ground-water systems are not connected, an increase in base flow was not observed.

In association with altered surface- and ground-water divides, surface mining can change ground-water flow systems. Shallow ground-water flow in agricultural watersheds is predominantly from recharge areas in the uplands between streams toward discharge areas along the streams. The diverse topography and scattered impoundments of water at Pond Creek and Big Branch tributary have created patterns of ground-water flow that are more localized than those at Big Slough and Hooker Creek. Recharge is from infiltration of precipitation through spoil and percolation from water-filled depressions above the water table. Ground water commonly flows to areas of discharge along streams or lakes that are at lower altitudes but not necessarily within the watershed. In watersheds that have been completely mined, such as Big Branch tributary, ground water recharged in one watershed may flow beneath surface-water divides to points of discharge in another watershed. Clearly, the effects of mining on flow systems must be determined individually for each mine.

Reclamation has simplified ground-water flow paths at Honey Creek tributary and Sulphur Creek tributary by removing impoundments above the water table and by grading the spoil banks to a more level topography. Recharge from spoil flows toward and through the final-cut lakes where some water is discharged (figs. 19, 20, 22, 23). The water table beneath Honey Creek tributary is below the elevation of the stream near the gage; consequently, ground water does not contribute to streamflow in the watershed. At Sulphur Creek tributary, ground water probably does not contribute to streamflow in the reaches of the stream that flow over graded spoil but does contribute to strea nflow in the unreclaimed headwaters and the unmined react north of the headwaters.

Shallow water levels in spoil, except in areas influenced by impoundments or final-cut lakes, generally are farther below land surface than those in till. In upland areas, water levels in till are generally within 1 to $8 \mathrm{f}^{\star}$ of land surface, whereas those in spoil are usually within 10 to 30 $\mathrm{ft}$ (figs. 20, 22, 28). Deeper water levels in spoil may be caused by greater hydraulic conductivity of spoil than till. Water may move through spoil at a greater rate than through till, and the water table in spoil may not rise to levels found in unmined watersheds. However, the greater hydraulic conductivity of spoil was not confirmed by slug te ts (table 6). A lower water table in spoil probably is not caused by nonsteady-state conditions because of slow resaturation of the spoil. The relatively fast rate at which the water table can rise is demonstrated by the time required for groundwater levels at Honey Creek tributary to equilibate after pumping was terminated in the final-cut lake. Wa+or levels reached equilibrium in less than 1 year (fig. 18).

Flow in the bedrock aquifers can by affected by mining and reclamation. If spoil has a greater vertical hydraulic conductivity than till, then increased recharge to the bedrock may result. Coal mining can increase the hydraulic connection between flow systems in the unconsolidated deposits and in the shallow bedrock by destroying the confining effect of underclay and shale or by creating lakes in direct contact with the bedrock. Underclay and shale may be fractured by blasting or drilling, and sump pumps and drains are often installed in holes dug into or through the underclay during mining. Water levels in the unconsolidated deposits are usually higher than those in the bedrock; consequently, lakes in contact with the bedrock and fractures and holes in confining layers provide pathways for increased recharge to the flow system in the bedrock. Reclamation may reduce recharge to the bedrock to the extent that lakes that cut in or near the surfece of the bedrock are often eliminated.

\section{SUMMARY AND CONCLUSIONS}

Six small watersheds in west-central Indiana were selected for study of the hydrologic effects of surface coal mining and reclamation. This report (1) describes and compares the hydrologic systems of the six watersheds, (2) identifies and discusses the geohydrologic effects of mining and reclamation on these watersheds, and (3) discusses potential effects of mining and reclamation on the geohydrology of small watersheds in west-central Indiana. The six watersheds include mined and reclaimed (Horey Creek 
tributary and Sulphur Creek tributary), mined and unreclaimed (Pond Creek and Big Branch tributary), and unmined agricultural land uses (Big Slough and Hooker Creek) and are each less than $3 \mathrm{mi}^{2}$ in area. A gaging station, at least one precipitation gage, and at least one ground-water well were installed in each watershed. Hydrologic and climatologic data for the 1981 and 1982 water years were analyzed in this report.

Annual mean temperatures for the 1981 and 1982 water years were cooler than the 30-year average (1951-80), and the 1982 water year was cooler than the 1981 water year. Annual precipitation was generally less than the 30-year average (about 41 in.) during the 1981 water year but was generally greater than the 30-year average during the 1982 water year. Monthly precipitation was greatest during May and least during January for the 1981 water year and was generally greatest during May and least during October or November for the 1982 water year. The study area was covered with a substantial amount of snow during the winter of the 1982 water year.

Discharge at the mined and unreclaimed watersheds is continuous and less variable than discharge at either the mined and reclaimed or the unmined agricultural watersheds. Periods of no flow occurred about 2 and 24 percent of the time at Big Slough and Hooker Creek, respectively, and about 21 and 76 percent of the time at Sulphur Creek tributary and Honey Creek tributary, respectively.

Total runoff was greatest at mined and unreclaimed watersheds, intermediate at unmined agricultural watersheds, and least at mined and reclaimed watersheds. Annual runoff expressed as a percentage of annual precipitation averaged 55.5 percent at Big Branch tributary, 39.5 percent at Pond Creek, 35.5 percent at Big Slough, 35.3 percent at Hooker Creek, 29.2 percent at Sulphur Creek tributary, and 16.6 percent at Honey Creek tributary.

Peak discharges were greatest at the agricultural watersheds and, to a lesser degree, at Honey Creek tributary. Peak discharges were smaller at the unreclaimed watersheds because of lakes, impoundments, and discontinuous drainage systems. Some areas of the unreclaimed watersheds do not contribute to surface runoff. Some lakes store and slowly release surface runoff. Small peak discharges at Sulphur Creek tributary were attributed to the dampening effect of the large final-cut lake at the mouth of the watershed.

The relations between precipitation and runoff were examined for eight storms during the 1981 and 1982 water years. No consistent pattern was apparent among watersheds in the volumes of runoff generated from these eight storms. Big Slough, Hooker Creek, and Honey Creek tributary responded more rapidly to thunderstorms than did the other watersheds, probably because of well-integrated drainage systems and low detention storage in these watersheds.
Till and spoil are the primary unconso'idated aquifers in the watersheds, whereas coal seams and fractured shale and sandstone are the primary consolidated a uifers. Underclays beneath coal seams and unfractured shale and siltstone act as confining layers for most of the bedrock aquifers. In the agricultural watersheds, recharge percolates through.till overlying bedrock, and flow is generally from the uplands to points of discharge along streams. Bedrock is mostly recharged by downward movement of water from the water-table aquifer in the till. Flow in the bedrock is primarily regional, toward discharge areas along the Wabash and Eel Rivers, although some water in the shallow bedrock discharges to streams in and near the watersheds.

Recharge to the spoil in the unreclaimed watersheds is from infiltration of precipitation in the spoil and from percolation of surface water stored in lakes above the water table. Shallow flow systems are more local than those in agricultural or reclaimed watersheds, and ground water may discharge to lakes in adjacent watersheds. Because water in some final-cut lakes is in direct contact with bedrock, the potential for recharge to the bedrock aquifers is increased. Recharge in reclaimed watersheds is from infiltration through spoil, and flow is toward points of discharge at lakes and streams. To the extent that reclamation eliminates impoundments and final-cut lakes in direct contact with the bedrock, the potential for recharge to the bedrock aquifers is reduced.

Hydrologic effects of mining were identified by comparing the hydrologic systems at mined and unreclaimed watersheds with those at unmined agricultural watersheds. Surface coal mining at Big Branch tributary and at Pond Creek has (1) increased base flow and created perennial flow, (2) increased annual runoff, (3) reduced peak flow rates and variation in flow, (4) decreased monthly runoff during wet months and increased runoff during dry months, (5) lengthened watershed response time to thunderstorms, (6) changed the relation of surface- and groundwater divides, thus resulting in ground-water inflow from adjacent watersheds at Big Branch tributary, (7) created numerous, local flow systems in the shallow' ground water, (8) lowered the water table in upland areas not influenced by water impoundments, and (9) increased recharge to the ground-water system in the bedrock.

Hydrologic effects of reclamation were identified by comparing the hydrologic systems at mined and reclaimed watersheds with those at mined and unre-laimed watersheds. Some of the hydrologic effects of reclamation are different at Honey Creek tributary than at Sulphur Creek tributary, primarily because of a final-cut lake at the mouth of the Sulphur Creek tributary watershed. Reclamation at Honey Creek tributary and Sulphur Creek tributary has (1) decreased base flow and created intermittent or ephemeral discharge, (2) decreased annual runoff, (3) increased peak flow rates at Honey Creek tributary and increased variation in flow, (4) increased monthly runoff during wet months 
and decreased runoff during dry months, (5) shortened watershed response time to thunderstorms at Honey Creek tributary, (6) reestablished the premining relation between surface- and ground-water divides at Sulphur Creek tributary, (7) created fewer local flow systems in the shallow ground water, and (8) decreased recharge to the bedrock aquifer by eliminating or backfilling final-cut lakes.

The overall hydrologic effects of mining and reclamation were identified by comparing the hydrologic systems at the mined and reclaimed watersheds with those at the unmined agricultural watersheds. As with the effects of reclamation, the overall effects of mining and reclamation were influenced by the presence or absence of a final-cut lake; consequently, some major differences between Honey Creek tributary and Sulphur Creek tributary are evident. Surface coal mining and reclamation at Honey Creek tributary and Sulphur Creek tributary has (1) decreased base flow and created ephemeral discharge at Honey Creek tributary, (2) decreased annual runoff, (3) decreased peak flow rates at Sulphur Creek tributary, (4) lengthened watershed response time to thunderstorms at Sulphur Creek tributary, (5) changed the relation between surface-' and ground-water divides at Honey Creek tributary, (6) increased recharge to the bedrock aquifer, and (7) lowered the water table in upland areas.

\section{REFERENCES CITED}

Agnew, A.F., and Corbett, D.M., 1973, Hydrology of a watershed containing flood-control reservoirs and coal surfacemining activity, in Huntnik, R.J., and Davis, Grant, eds., Ecology and reclamation of devastated land, v. 1: New York, Gordon and Breach, p. 159-173.

Banaszak, K.J., 1980, Coals as aquifers in the eastern United States, in Graves, D.H., ed., 1980 symposium on surface mining hydrology, sedimentology, and reclamation, Lexington, Ky., December 1-5, 1980, Proceedings: University of Kentucky, Office of Engineering Services, p. 235-241.

1985, Potential effects on ground water of a hypothetical surface mine in Indiana: Ground Water Monitoring Review, v. 5 , no. 1 , p. 51-57.

Bobo, L.L., and Eikenberry, S.E., 1982, Water-quality and other hydrologic data collected in and around a surface coal mine, Clay and Vigo Counties, Indiana, 1977-80: U.S. Geological Survey Open-File Report 82-639, 117 p.

Bouwer, Herman, and Rice, R.C., 1976, A slug test for determining hydraulic conductivity of unconfined aquifers with completely or partially penetrating wells: Water Resources Research, v. 12, no. 3, p. 423-428.

Brabets, T.P., 1984, Runoff and water-quality characteristics of surface-mined lands in Illinois: U.S. Geological Survey Water-Resources Investigations Report 83-4265, 78 p.

Cable, L.W., and Robison, T.M., 1973, Hydrogeology of the principal aquifers in Sullivan and Greene Counties, Indiana: Indiana Department of Natural Resources, Division of Water, Bulletin 35, $26 \mathrm{p}$.

Cable, L.W., Watkins, F.A., Jr., and Robison, T.M., 1971, Hydrogeology of the principal aquifers in Vigo and Clay
Counties, Indiana: Indiana Department of Natural Resources, Division of Water, Bulletin 34, 34 p.

Cartwright, Keros, and Hunt, C.S., 1981, Hydrogeologic aspects of coal mining in Illinois - An overview: Illinois Institute of Natural Resources, State Geological Survey Division, Environmental Geology Notes 90,19 p.

Collier, C.R., Pickering, R.J., and Musser, J.J., eds., 1970, Influences of strip mining on the hydrologic environment of parts of Beaver Creek basin, Kentucky, 1955-66: U.S. Geological Survey Professional Paper 427-C, 80 f.

Cooper, H.H., Jr., Bredehoeft, J.D., and Papadopul's, L.S., 1967, Response of a finite diameter well to an inst $>$ ntaneous charge of water: Water Resources Research, v. 3, no. 2, p. 263-269.

Corbett, D.M., 1965, Water supplied by coal surface mines, Pike County, Indiana: Indiana University, Water Resources Research Center, Report of Investigations no. 1, 67 p.

1969, Acid mine-drainage problem of the Patoka River watershed, southwestern Indiana: Indiana University, Water Resources Research Center, Report of Investigaticns no. 4, $173 \mathrm{p}$.

Corbett, D.M., and Agnew, A.F., 1968, Coal mining effect on Busseron Creek watershed, Sullivan County, Indiana: Indiana University, Water Resources Research Center, Report of Investigations no. 2, $187 \mathrm{p}$.

Curtis, W.R., 1973, Effects of strip mining on the hycrology of small mountain watersheds in Appalachia, in Hunt -ik, R.J., and Davis, Grant, eds., Ecology and reclamation of devastated land, v. 1: New York, Gordon and Breach, p. 145-157. 1977, Hydrologic aspects of surface mining in the East: Society of American Foresters, Proceedings, Berea, Ky., p. 152-157 (reprint).

-1978, Effects of surface mining on hydrology, erosion, and sedimentation in eastern Kentucky, in Fourth Kentıcky Coal Refuse Disposal and Utilization Seminar, Lexing ${ }^{+}$, Ky., June 6-7, 1978: University of Kentucky, Institute for Mining and Minerals Research, p. 17-19 (reprint).

Emerson, D.G., 1981, Progress report on the effects of surface mining on the surface-water hydrology of selected basins in the Fort Union Coal Region, North Dakota and Montana: U.S. Geological Survey Open-File Report 81-678, 28 p.

Freeze, R.A., and Cherry, J.A., 1979, Groundwater: Englewood Cliffs, N.J., Prentice-Hall, 604 p.

Gregory, K.J., and Walling, D.E., 1973, Drainage basir form and process, a geomorphological approach: New York, Halsted Press, $458 \mathrm{p}$.

Grubb, H.F., and Ryder, P.D., 1972, Effects of coal mining on the water resources of the Tradewater River basin, Kentucky: U.S. Geological Survey Water-Supply Paper 1940, 83 p.

Heath, R.C., 1984, Ground-water regions of the Unit ${ }^{\prime}$ States: U.S. Geological Survey Water-Supply Paper 2242, 78 p.

Hoyt, W.G., and others, 1936, Studies of relations of rcinfall and runoff in the United States: U.S. Geological Survey WaterSupply Paper 772, $301 \mathrm{p}$.

Langbein, W.B., and Iseri, K.T., 1960, General surface-water techniques; General introduction and hydrologic definitions, Manual of hydrology; pt. 1: U.S. Geological Surv yy WaterSupply Paper 1541-A, 29 p.

Lindorff, D.E., 1980, Hydrogeology of surface coal mines in Illinois, in Graves, D.H., ed., 1980 symposium on surface 
mining hydrology, sedimentology, and reclamation. Lexington, Ky., December 1-5, 1980, Proceedings: University of Kentucky, Office of Engineering Services, p. 33-46.

Martin, J.D., Crawford, C.G., Duwelius, R.F., and Renn, D.E., 1990, Description of the physical environment and coalmining history of west-central Indiana, with emphasis on six small watersheds: U.S. Geological Survey Water-Supply Paper 2368-A, 38 p.

McCarter, Paul, Jr., 1982, Soil survey of Clay County, Indiana: U.S. Department of Agriculture, Soil Conservation Service, and Purdue University Agricultural Experiment Station, 152 p., 56 maps.

Meadows, M.E., and Blandford, G.E., 1983, Improved methods and guidelines for modeling stormwater runoff from surface coal mine lands: University of Kentucky, Water Resources Research Institute, Research Report no. 147, 133 p.

Peters, J.G., 1981, Effects of surface mining on water quality in a small watershed, Sullivan County, Indiana: U.S. Geological Survey Open-File Report 81-543, 61 p.

Razem, A.C., 1984, Ground-water hydrology and quality before and after strip mining of a small watershed in Jefferson County, Ohio: U.S. Geological Survey Water-Resources Investigations Report 83-4215, 39 p.

Renn, D.E., Duwelius, R.F., Keeton, C.R., and Tyler, J.W., Jr., 1985, Hydrologic data in small watersheds, coal-mining region, west-central Indiana, October 1980 to June 1983, and instrumentation and methods of collecting the data: U.S. Geological Survey Open-File Report 85-402, 177 p.

Schubert, J.P., 1980, Fracture flow of groundwater in coalbearing strata, in Graves, D.H., ed., 1980 symposium on surface mining hydrology, sedimentology, and reclamation, Lexington, Ky., December 1-5, 1980, Proceedings: University of Kentucky, Office of Engineering Services, p. 61-73.

Scott, A.G., 1984, Analysis of characteristics of simulated flows from small surface-mined and undisturbed Appalachian watersheds in the Tug Fork basin of Kentucky, Virginia, and West Virginia: U.S. Geological Survey Water-Resources Investigations Report 84-4151, 169 p.

Skibitzke, H.E., 1958, An equation for potential distribution about a well being bailed: U.S. Geological Survey Open-File Report 58-96, 11 p.

Stoner, J.D., 1983, Probable hydrologic effects of subsurface mining: Ground Water Monitoring Review, v. 3, no. 1, p. 128-137.

U.S. Department of Agriculture, Agricultural Research Service and Ohio State University, 1983, Results in Jefferson County, Ohio-Research on the hydrology and water quality of watersheds subjected to surface mining: U.S. Department of the Interior, Bureau of Mines, Mining Research Contract Nos. J0166054 and J0166055 Report, 177 p.

U.S. Department of Commerce, 1980-82, Climatological data, annual summary, Indiana: U.S. Department of Commerce, National Oceanic and Atmospheric Administration, v. $85-87$, no. 13 , variable pagination.

1982a, Climatography of the United States No. 81 (by State), monthly normals of temperature, precipitation, and heating and cooling degree days, 1951-80, Indiana: U.S. Department of Commerce, National Oceanic and Atmospheric Administration, variable pagination. 1982b, Local climatological data, annual summary with comparative data, 1982, Indianapolis, India 7a: U.S. Department of Commerce, National Oceanic and Atmospheric Administration, variable pagination.

U.S. Geological Survey, 1977, National handhook of recommended methods for water-data acquisition: U.S. Geological Survey, Office of Water Data Coordination, variable pagination.

Wangsness, D.J., 1982, Reconnaissance of stream biota and physical and chemical water quality in areas of selected land use in the coal-mining region, southw'estern Indiana, 1979-80: U.S. Geological Survey Open-File Report 82-566, $43 \mathrm{p}$.

Wangsness, D.J., and others, 1981a, Hydrolngy of area 32 , eastern region, Interior Coal Province, Indiana: U.S. Geological Survey Water-Resources Investigetions Open-File Report 81-498, 76 p.

1981b, Hydrology of area 33, eastern region, Interior Coal Province, Indiana and Kentucky: U.S. Geological Survey Water-Resources Investigations Open-File Report 81-423, 84 p.

1983, Hydrology of area 30, eastern region, Interior Coal Province, Illinois and Indiana: U.S. Geological Survey Water-Resources Investigations Open-File Report 82-1005, $82 \mathrm{p}$.

Watkins, F.A., Jr., and Jordan, D.G., 1962a, Ground-water resources of west-central Indiana, preliminary report-Clay County: Indiana Department of Conservation, Division of Water Resources, Bulletin 16, 309 p.

$1962 b$, Ground-water resources of west-central Indiana, preliminary report-Sullivan County: Indiana Department of Conservation, Division of Water Resources, Bulletin 14, $345 \mathrm{p}$.

1963, Ground-water resources of west-central Indiana, preliminary report-Vigo County: Indiane Department of Conservation, Division of Water Resources, Bulletin 17, $358 \mathrm{p}$.

Weiss, J.S., and Razem, A.C., 1984, Simulatior of ground-water flow in a mined watershed in eastern Ohio: Ground Water, v. 22 , no. 5 , p. 549-560.

Wells, L.G., Ward, A.D., and Phillips, R.E., 1983, Predicting infiltration and surface runoff from reconst ucted spoils and soils: University of Kentucky, Water Resources Research Institute, Research Report 143, 44 p.

Whitlatch, G.I., 1933, The clay resources of Indiana: Indiana Department of Conservation, Division of Geology, Publication $123,298 \mathrm{p}$.

Wilber, W.G., and Boje, R.R., 1982, Reconnaissance for determining effects of land use and surficial geology on concentrations of selected elements on streambed materials from the coal-mining region, southwestern Indiana, October 1979 to March 1980: U.S. Geological Survey Water-Resources Investigations Report 82-4013, 39 p.

Wilber, W.G., Crawford, C.G., Renn, D.E., Ragone, S.E., and Wangsness, D.J., 1980, Preliminary assessment of the factors affecting water quality in the coal-mining region, southwestern Indiana, March to October 1979, in Warner, R.E., and Clark, P.E., eds., Water resources and land-use manage- 
ment in Indiana, a symposium, Marshall, Indiana, June 12-14, 1980, Proceedings: Indiana Water Resources Association, p. 215-234.

Wilber, W.G., Renn, D.E., and Crawford, C.G., 1985, Effects of land use and surficial geology on flow and water quality of streams in the coal-mining region of southwestern Indiana, October 1979 through September 1980: U.S. Geological Survey Water-Resources Investigations Report 85-4234, $49 \mathrm{p}$.

Williams, G.R., and others, 1940, Natural water loss in selected drainage basins: U.S. Geological Survey Water-Supply Paper 846,62 p.
Wilson, J.L., and Hamilton, D.A., 1978, Influence of strip mines on regional ground-water flow: Journa' of the Hydraulics Division, Proceedings of the America $\uparrow$ Society of Civil Engineers, v. 104, no. HY9, p. 1213-122.3.

Zogorski, J.S., Ramey, D.S., Lambert, P.W., Martin, J.D., and Warner, R.E., 1981, Hydrologic evaluation of a hypothetical coal-mining site near Chrisney, Spencer County, Indiana: U.S. Geological Survey Open-File Report 80-1107, $133 \mathrm{p}$. 
FIGURE 9 AND TABLE 5 

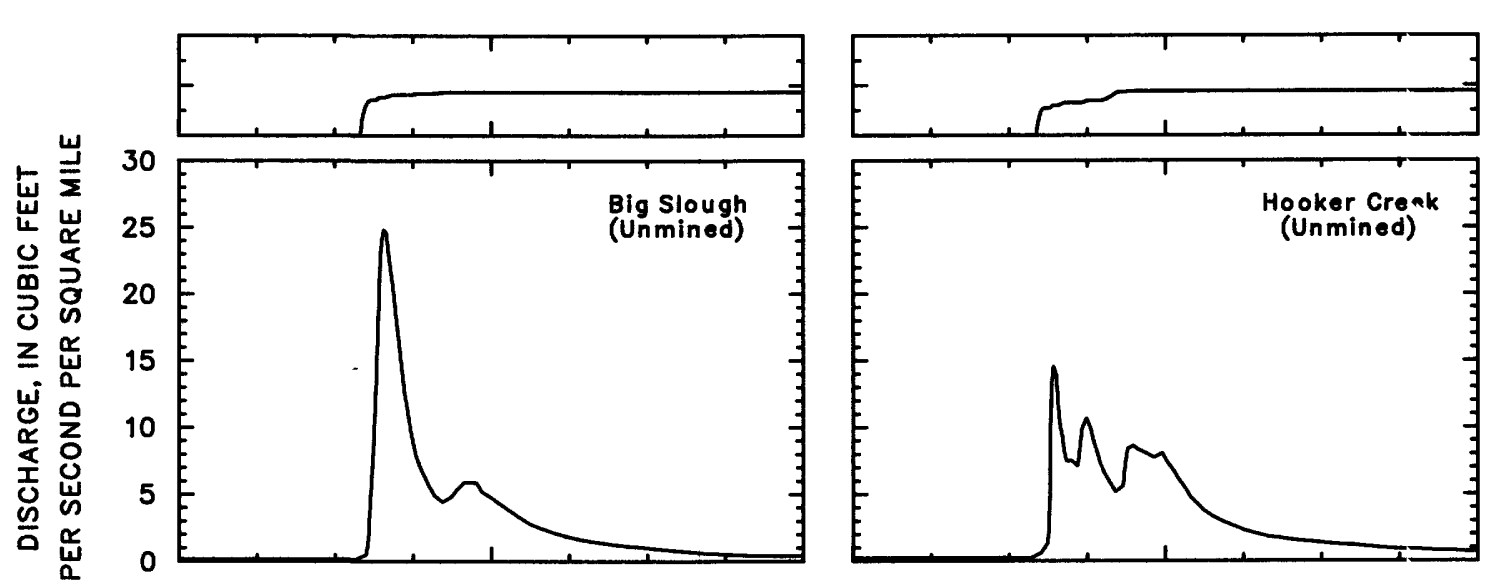

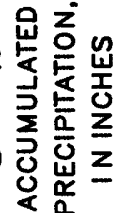
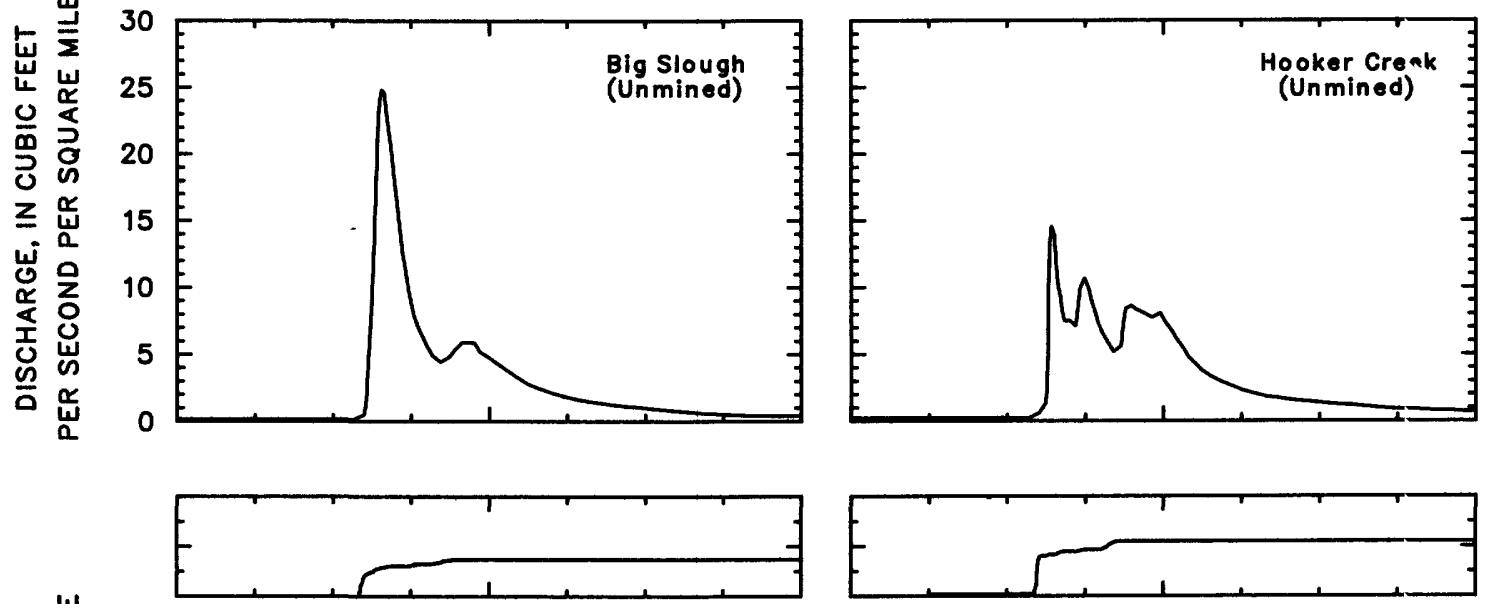

는

눈은 때
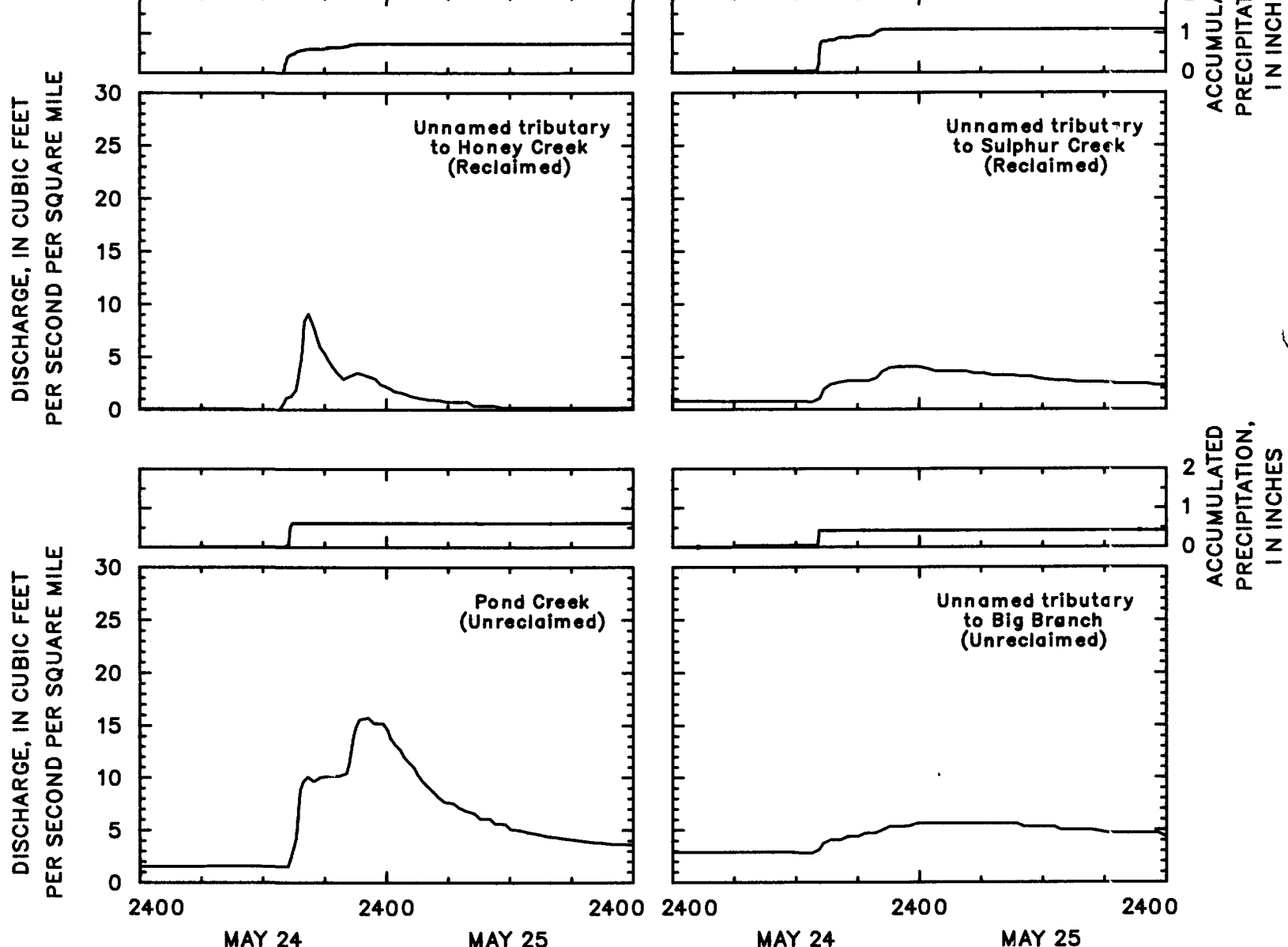

Figure 9A. Instantaneous discharge and accumulated precipitation for six study watersheds for thunderstorm of May 24, 1981. 
Table $5 A$. Volumes of precipitation and runoff and times from beginning of rise to peak discharge at six study wate "sheds for the thunderstorm of May 24, 1981

[in., inch]

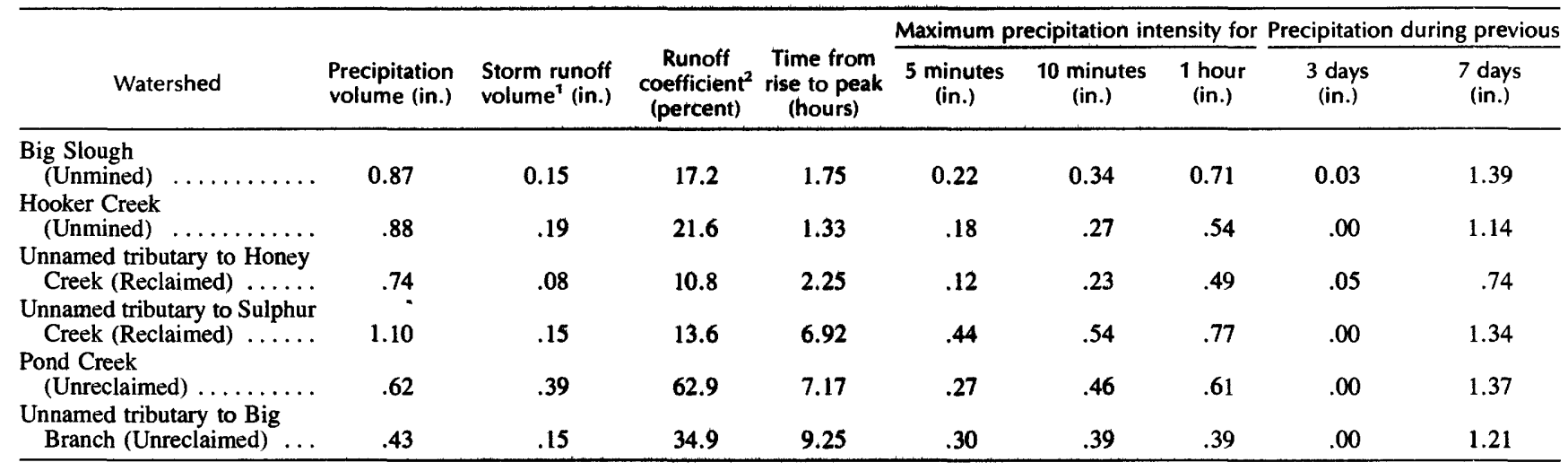

${ }^{1}$ Storm runoff volume is the total runoff volume minus the base-flow volume.

${ }^{2}$ Runoff coefficient is storm runoff volume divided by precipitation volume multiplied by 100 percent. 

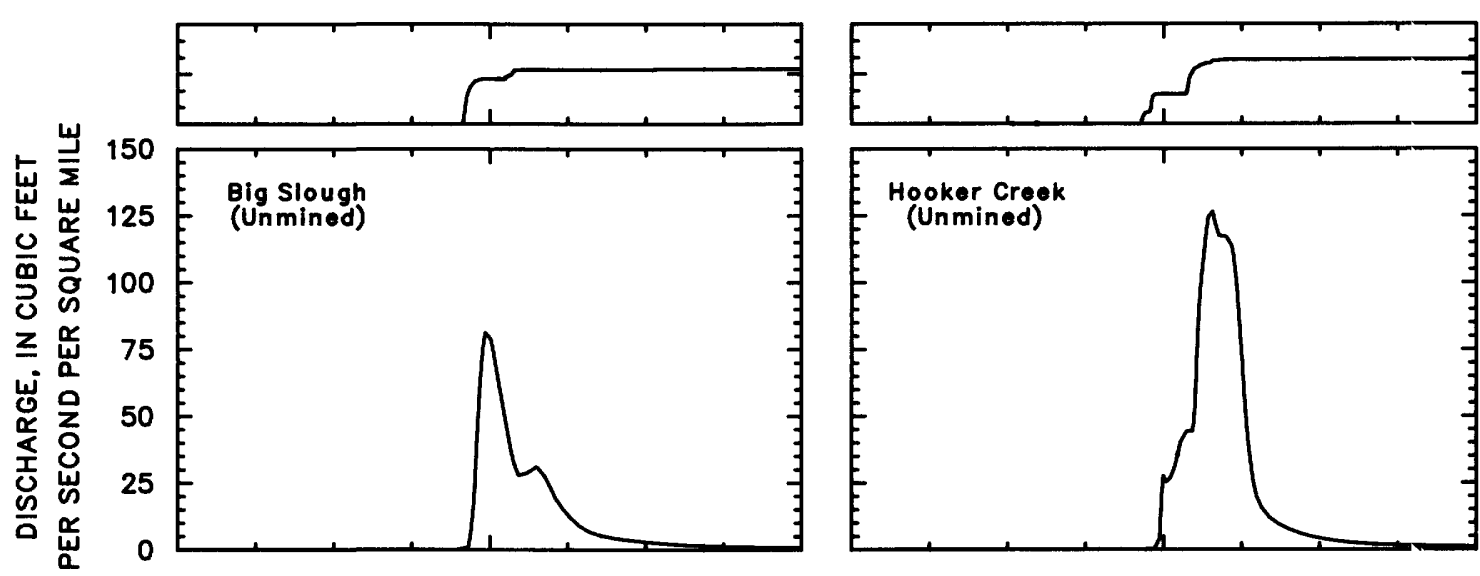

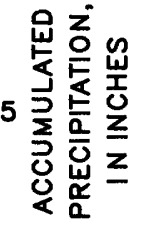
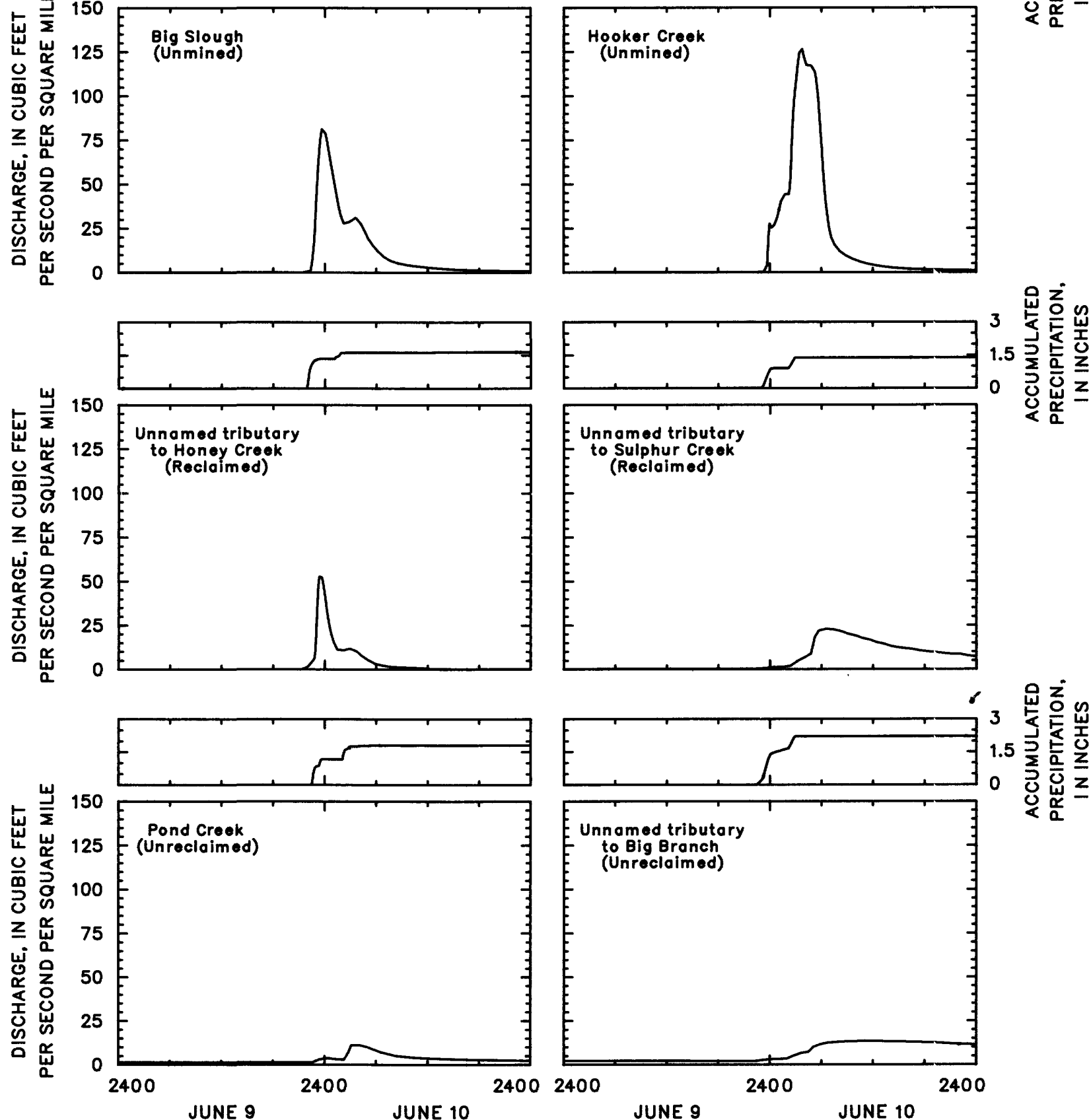

Figure $9 B$. Instantaneous discharge and accumulated precipitation at six study watersheds for thunderstorm of June 9-10, 1981. 
Table $5 B$. Volumes of precipitation and runoff and times from beginning of rise to peak discharge at six study watersheds for the thunderstorm of June 9-10, 1981

[in., inch]

\begin{tabular}{|c|c|c|c|c|c|c|c|c|c|}
\hline \multirow[b]{2}{*}{ Watershed } & \multirow[b]{2}{*}{$\begin{array}{l}\text { Precipitation } \\
\text { volume (in.) }\end{array}$} & \multirow[b]{2}{*}{$\begin{array}{l}\text { Storm runoff } \\
\text { volume }^{1} \text { (in.) }\end{array}$} & \multirow[b]{2}{*}{$\begin{array}{l}\begin{array}{l}\text { Runoff } \\
\text { coefficient }\end{array}{ }^{2} \\
\text { (percent) }\end{array}$} & \multirow{2}{*}{$\begin{array}{l}\text { Time from } \\
\text { rise to peak } \\
\text { (hours) }\end{array}$} & \multicolumn{3}{|c|}{ Maximum precipitation intensity for } & \multicolumn{2}{|c|}{ recipitation during previous } \\
\hline & & & & & 5 minutes & $10 \underset{\text { (in.) }}{\text { minutes }}$ & $\begin{array}{l}1 \text { hour } \\
\text { (in.) }\end{array}$ & $\begin{array}{l}3 \text { days } \\
\text { (in.) }\end{array}$ & $\begin{array}{l}7 \text { days } \\
\text { (in.) }\end{array}$ \\
\hline $\begin{array}{l}\text { Big Slough } \\
\text { (Unmined) }\end{array}$ & 1.65 & 0.53 & 32.1 & 1.67 & 0.27 & 0.53 & 1.30 & 0.00 & 0.29 \\
\hline $\begin{array}{l}\text { Hooker Creek } \\
\text { (Unmined) } \ldots \ldots \ldots \ldots\end{array}$ & 1.93 & .97 & 50.3 & 5.17 & .27 & .40 & .85 & .00 & .46 \\
\hline $\begin{array}{l}\text { Unnamed tributary to Honey } \\
\text { Creek (Reclaimed) } \ldots . . . \\
\text { Unnamed tributary to Sulphur }\end{array}$ & 1.65 & .21 & 12.7 & 1.42 & .27 & .53 & 1.30 & .00 & .09 \\
\hline $\begin{array}{l}\text { Creek (Reclaimed) ....... } \\
\text { Pond Creek }\end{array}$ & 1.39 & .73 & 52.5 & 6.00 & .11 & .18 & .85 & .00 & .23 \\
\hline $\begin{array}{l}\text { (Unreclaimed) } \ldots \ldots \ldots \\
\text { Unnamed tributary to } \mathrm{Big}\end{array}$ & 1.81 & .15 & 8.3 & 5.25 & .24 & .47 & 1.04 & .00 & .18 \\
\hline Branch (Unreclaimed) ... & 2.22 & .75 & 33.8 & 10.75 & .14 & .24 & 1.15 & .00 & .37 \\
\hline
\end{tabular}

${ }^{1}$ Storm runoff volume is the total runoff volume minus the base-flow volume.

${ }^{2}$ Runoff coefficient is storm runoff volume divided by precipitation volume multiplied by 100 percent. 

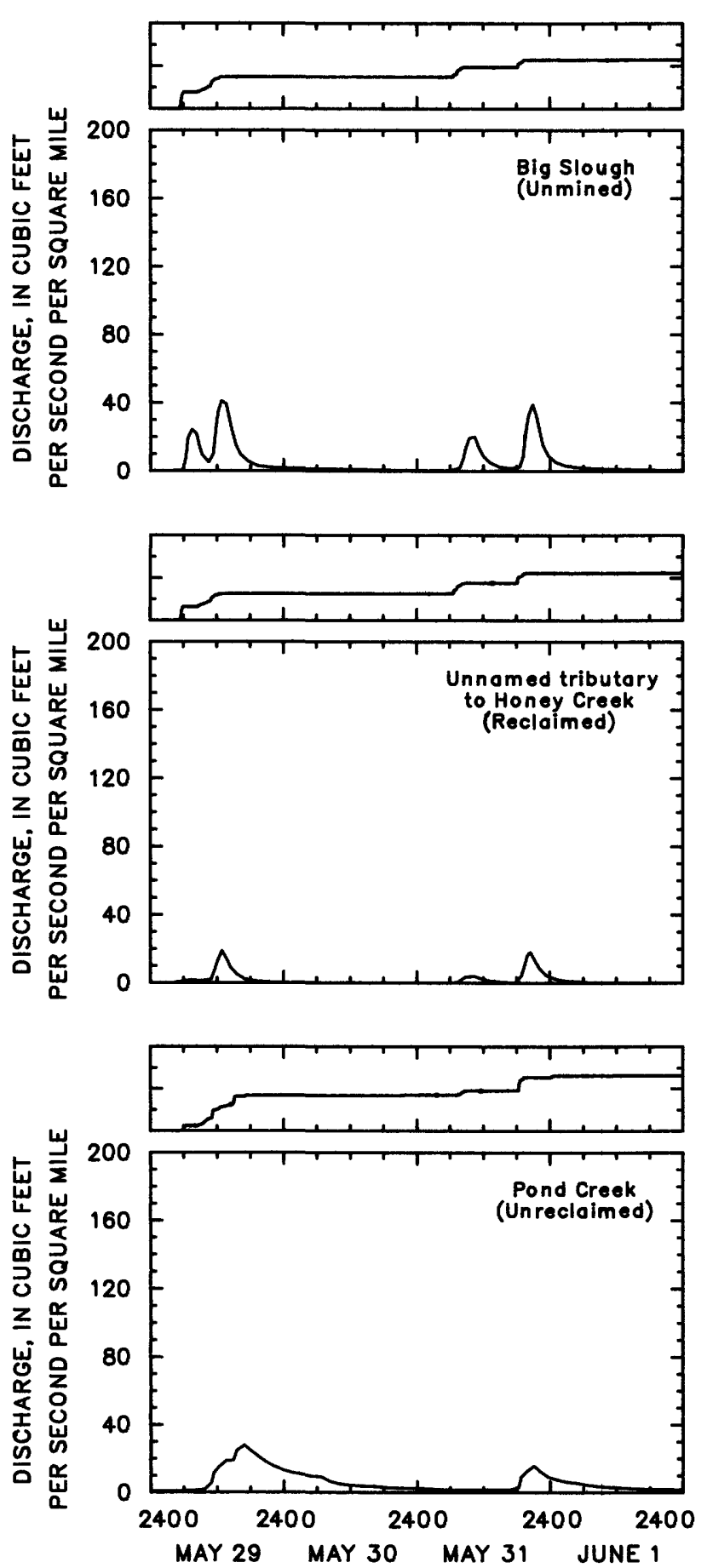
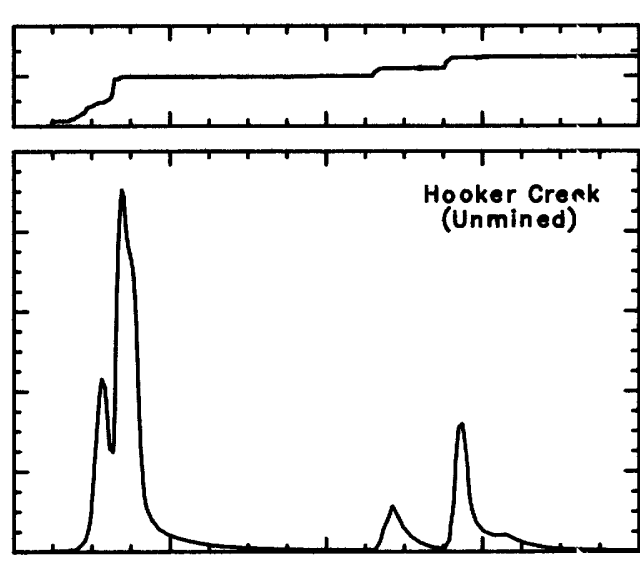

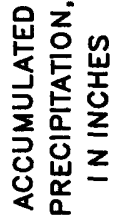

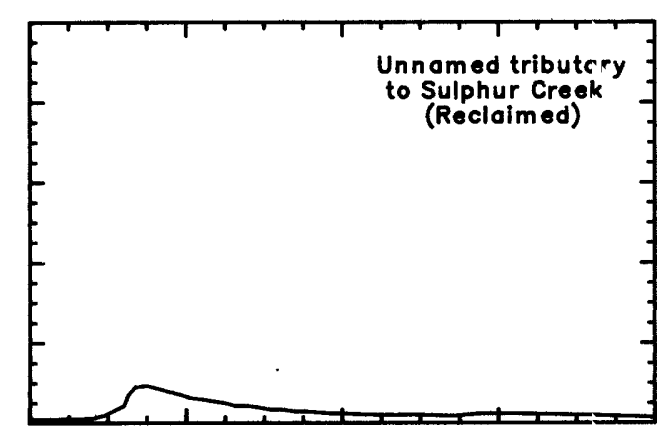

它 노은

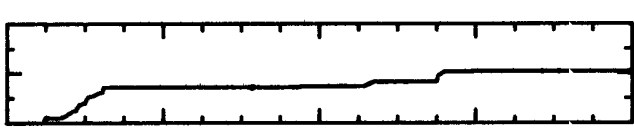

$2 \frac{5}{\Sigma} \frac{1}{2}$ 0 导岕

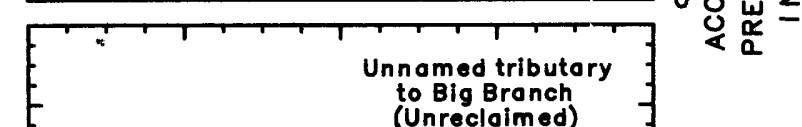

Figure $9 C$. Instantaneous discharge and accumulated precipitation for six study watersheds for thinderstorm of May 29, 1982. 
Table 5C. Volumes of precipitation and runoff and times from beginning of rise to peak discharge at six study watersheds for the thunderstorm of May 29, 1982

[in., inch]

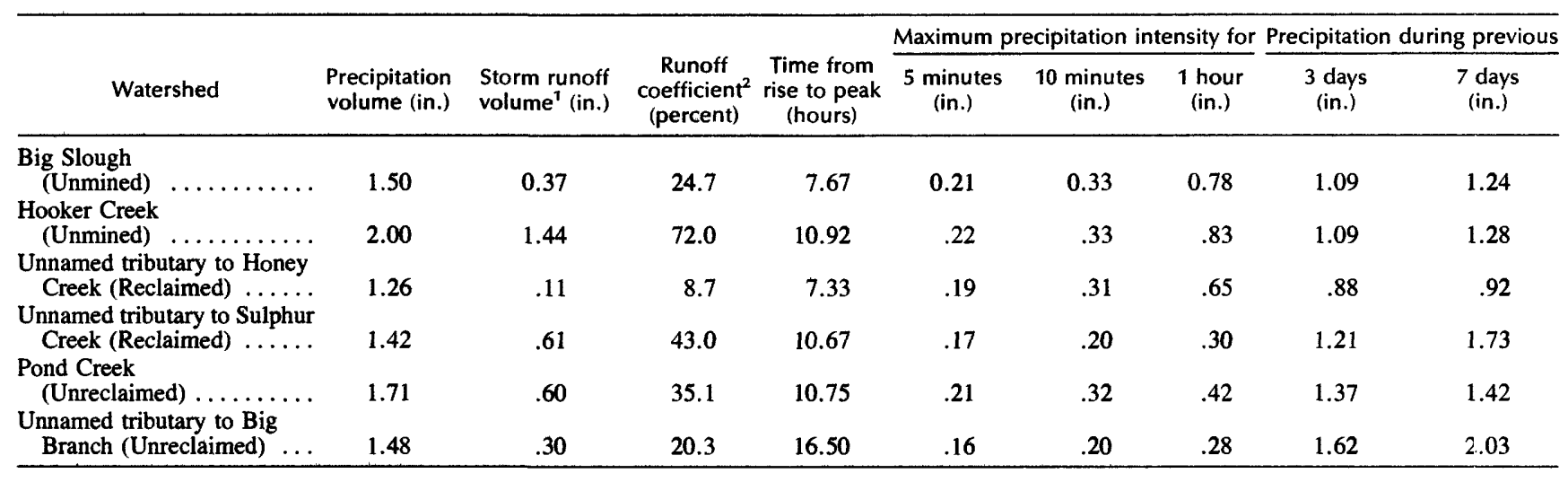

${ }^{1}$ Storm runoff volume is the total runoff volume minus the base-flow volume.

${ }^{2}$ Runoff coefficient is storm runoff volume divided by precipitation volume multiplied by 100 percent. 

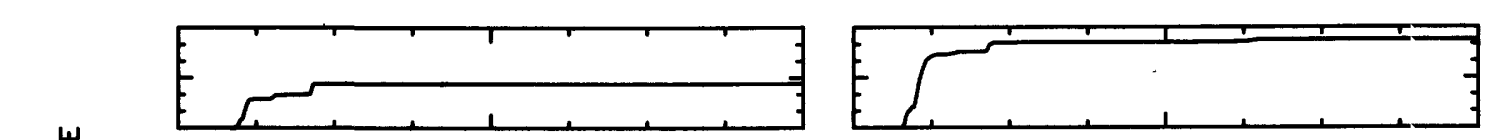

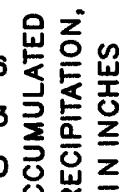
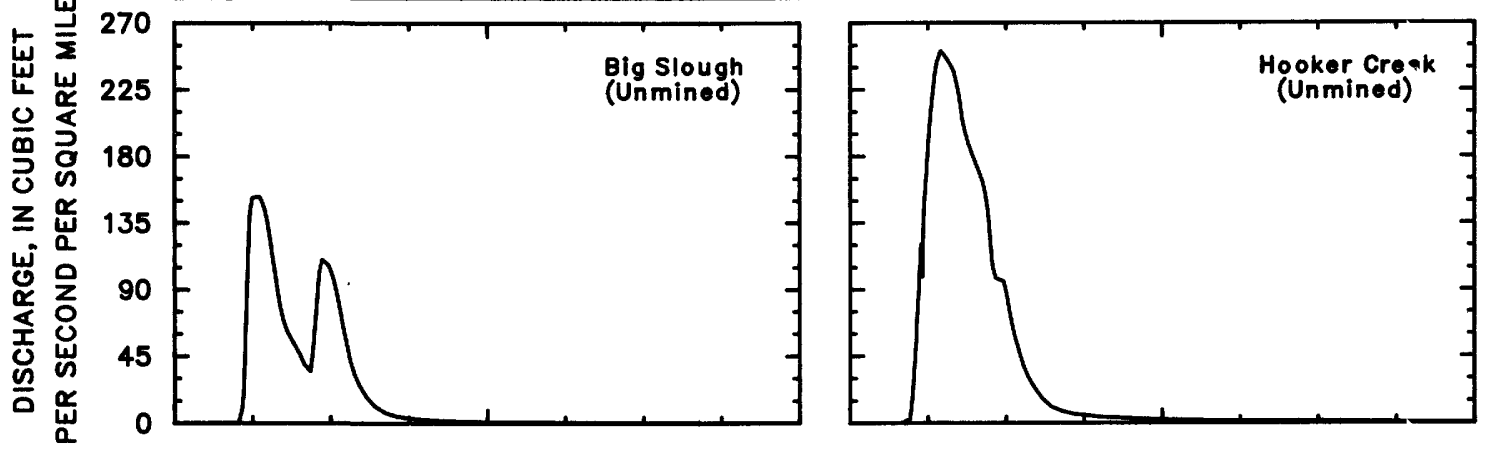

$<\frac{0}{\alpha}$
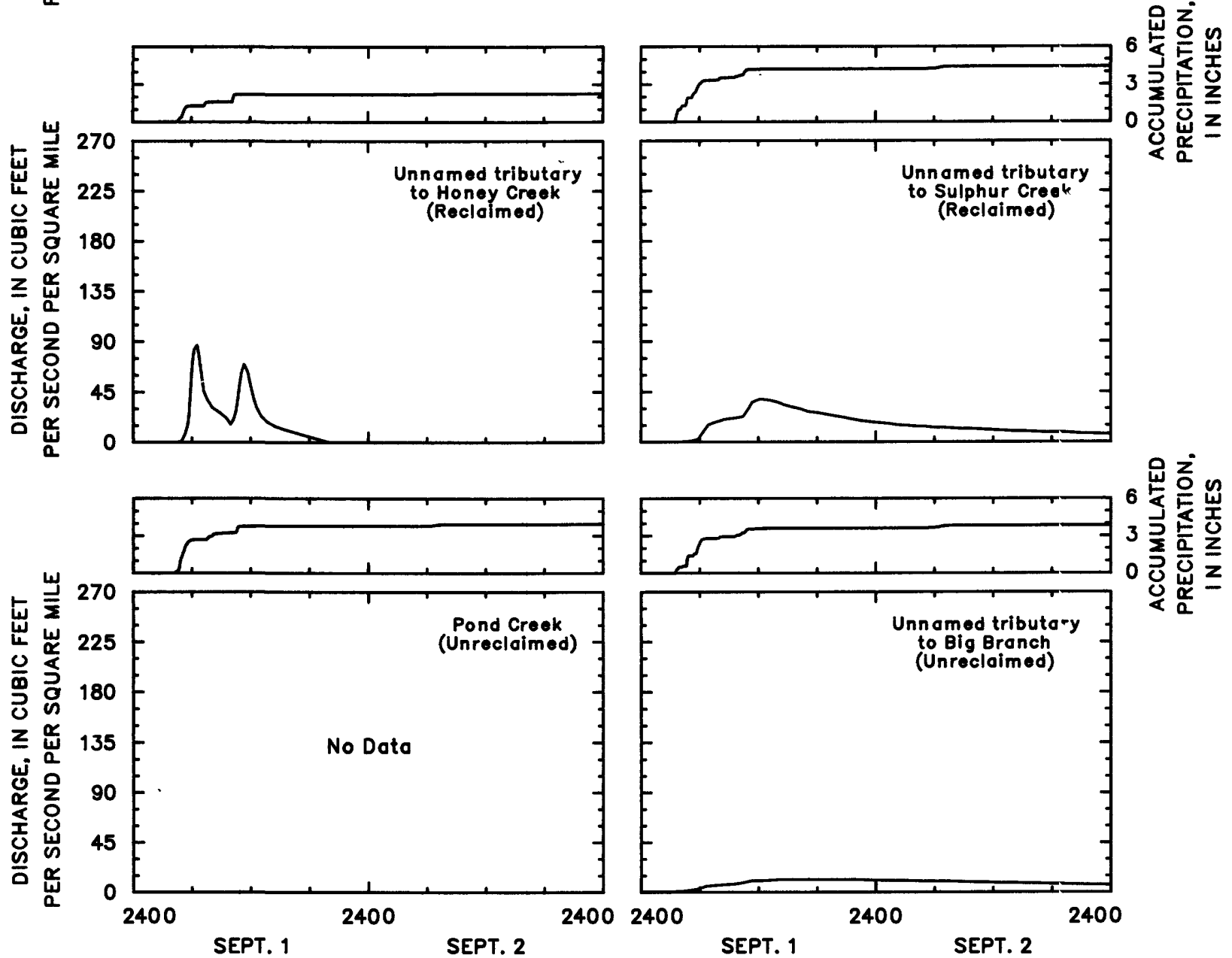

Figure 9D. Instantaneous discharge and accumulated precipitation for six study watersheds for thunderstorm of September 1, 1982. 
Table $5 D$. Volumes of precipitation and runoff and times from beginning of rise to peak discharge at six study watersheds for the thunderstorm of September 1, 1982

$[-$, no data available; in., inch]

\begin{tabular}{|c|c|c|c|c|c|c|c|c|c|}
\hline \multirow[b]{2}{*}{ Watershed } & \multirow[b]{2}{*}{$\begin{array}{l}\text { Precipitation } \\
\text { volume (in.) }\end{array}$} & \multirow[b]{2}{*}{$\begin{array}{l}\text { Storm runoff } \\
\text { volume }^{1} \text { (in.) }\end{array}$} & \multirow[b]{2}{*}{$\begin{array}{l}\text { Runoff } \\
\text { coefficient } \\
\text { (percent) }\end{array}$} & \multirow[b]{2}{*}{$\begin{array}{l}\text { Time from } \\
\text { rise to peak } \\
\text { (hours) }\end{array}$} & \multicolumn{5}{|c|}{ Maximum precipitation intensity for Precipitation during previous } \\
\hline & & & & & 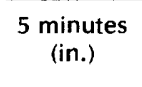 & $\begin{array}{l}10 \text { minutes } \\
\text { (in.) }\end{array}$ & $\begin{array}{l}1 \text { hour } \\
\text { (in.) }\end{array}$ & $\begin{array}{l}3 \text { days } \\
\text { (in.) }\end{array}$ & $\begin{array}{l}7 \text { days } \\
\text { (in.) }\end{array}$ \\
\hline $\begin{array}{l}\text { Big Slough } \\
\text { (Unmined) }\end{array}$ & 2.64 & 1.23 & 46.6 & 1.58 & 0.28 & 0.53 & 1.62 & 0.81 & 1.21 \\
\hline $\begin{array}{l}\text { Hooker Creek } \\
\text { (Unmined) } \ldots \ldots \ldots \ldots\end{array}$ & 5.26 & 2.19 & 41.6 & 2.33 & .38 & .68 & 2.84 & 1.14 & 1.36 \\
\hline $\begin{array}{l}\text { Unnamed tributary to Honey } \\
\text { Creek (Reclaimed) } \ldots . . .\end{array}$ & 2.26 & .60 & 26.6 & 1.58 & .30 & .52 & 1.21 & .89 & 1.23 \\
\hline $\begin{array}{l}\text { Unnamed tributary to Sulphur } \\
\text { Creek (Reclaimed) } \ldots \ldots\end{array}$ & 4.42 & 1.84 & 41.6 & 8.58 & .39 & .58 & 1.29 & 1.46 & 1.71 \\
\hline $\begin{array}{l}\text { (Unreclaimed) .......... } \\
\text { Unnamed tributary to Big }\end{array}$ & 3.95 & - & - & - & .40 & .72 & 2.25 & 1.55 & 1.75 \\
\hline Branch (Unreclaimed) $\ldots$ & 3.84 & .92 & 24.0 & 10.00 & .52 & .75 & 1.34 & 1.25 & 1.50 \\
\hline
\end{tabular}

${ }^{1}$ Storm runoff volume is the total runoff volume minus the base-flow volume

${ }^{2}$ Runoff coefficient is storm runoff volume divided by precipitation volume multiplied by 100 percent. 

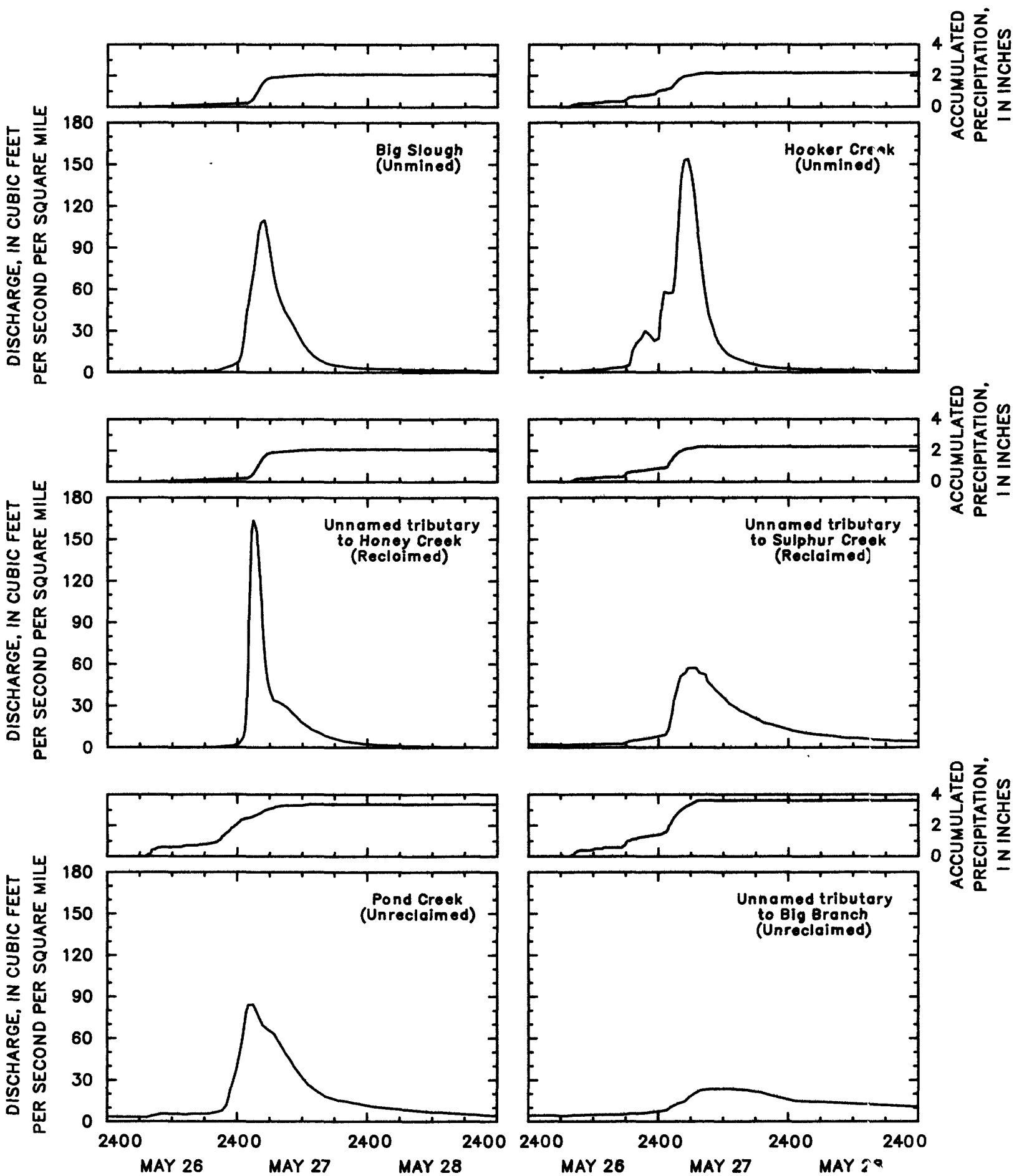

Figure 9E. Instantaneous discharge and accumulated precipitation for six study watersheds for frontal storm of May 26-27, 1981. 
Table 5E. Volumes of precipitation and runoff and times from beginning of rise to peak discharge at six study watersheds for the frontal storm of May 26-27, 1981

[in., inch]

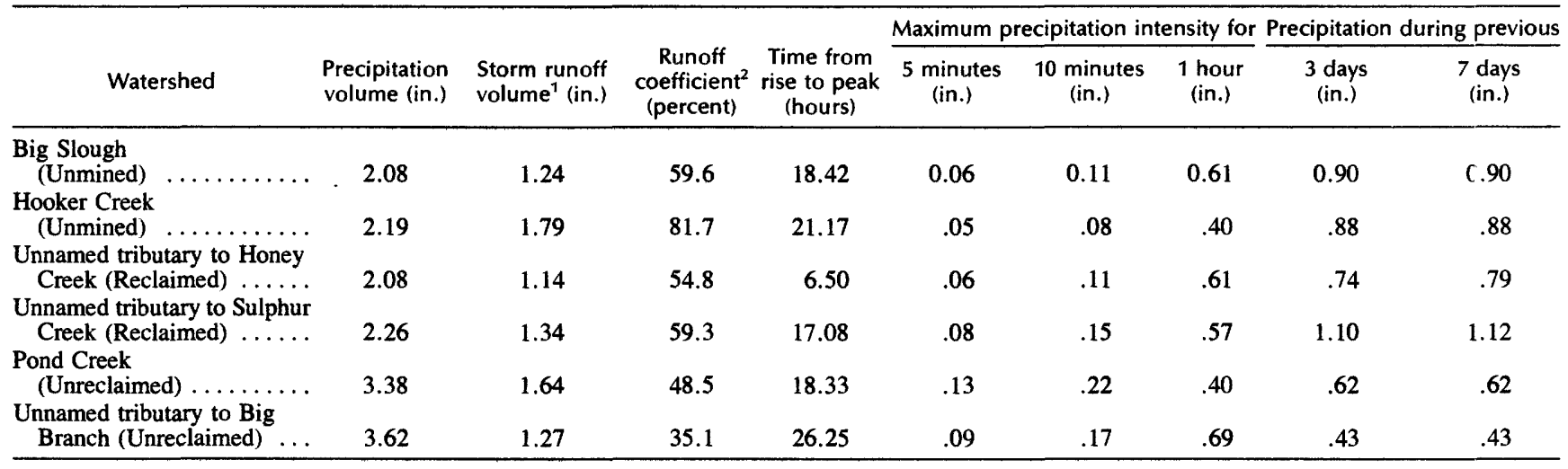

${ }^{1}$ Storm runoff volume is the total runoff volume minus the base-flow volume.

${ }^{2}$ Runoff coefficient is storm runoff volume divided by precipitation volume multiplied by 100 percent. 

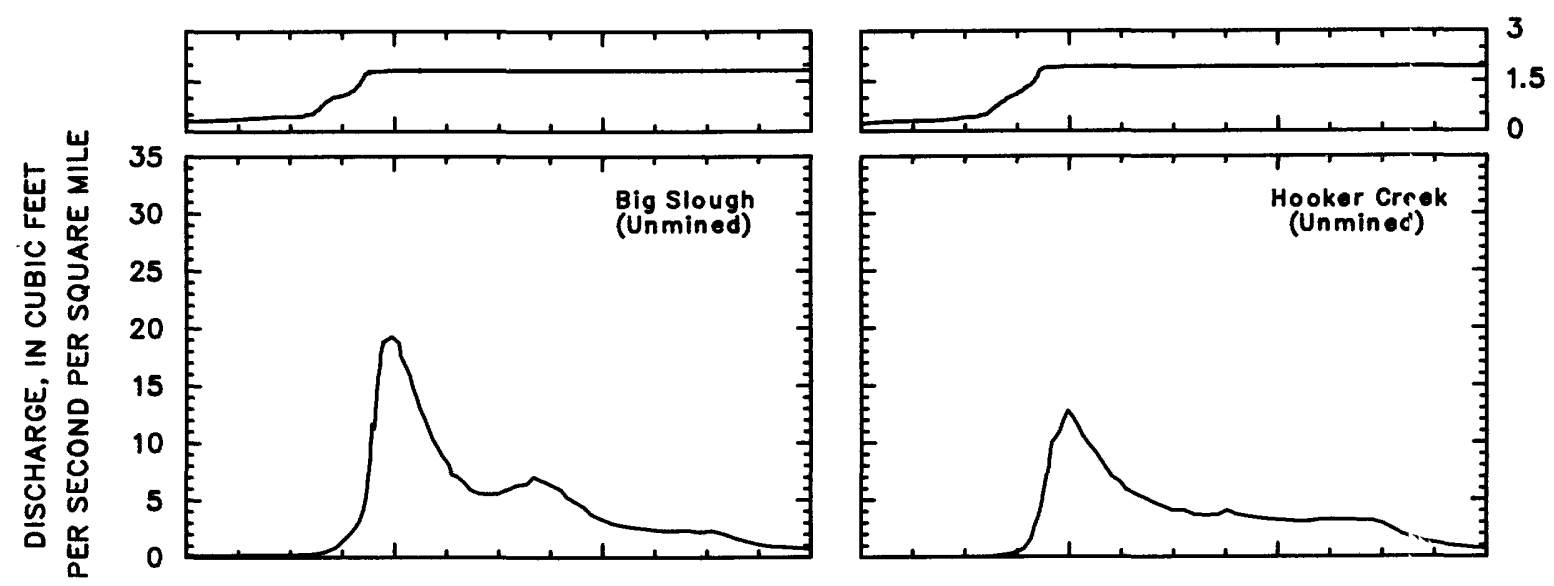

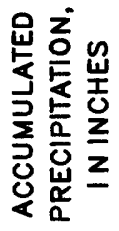
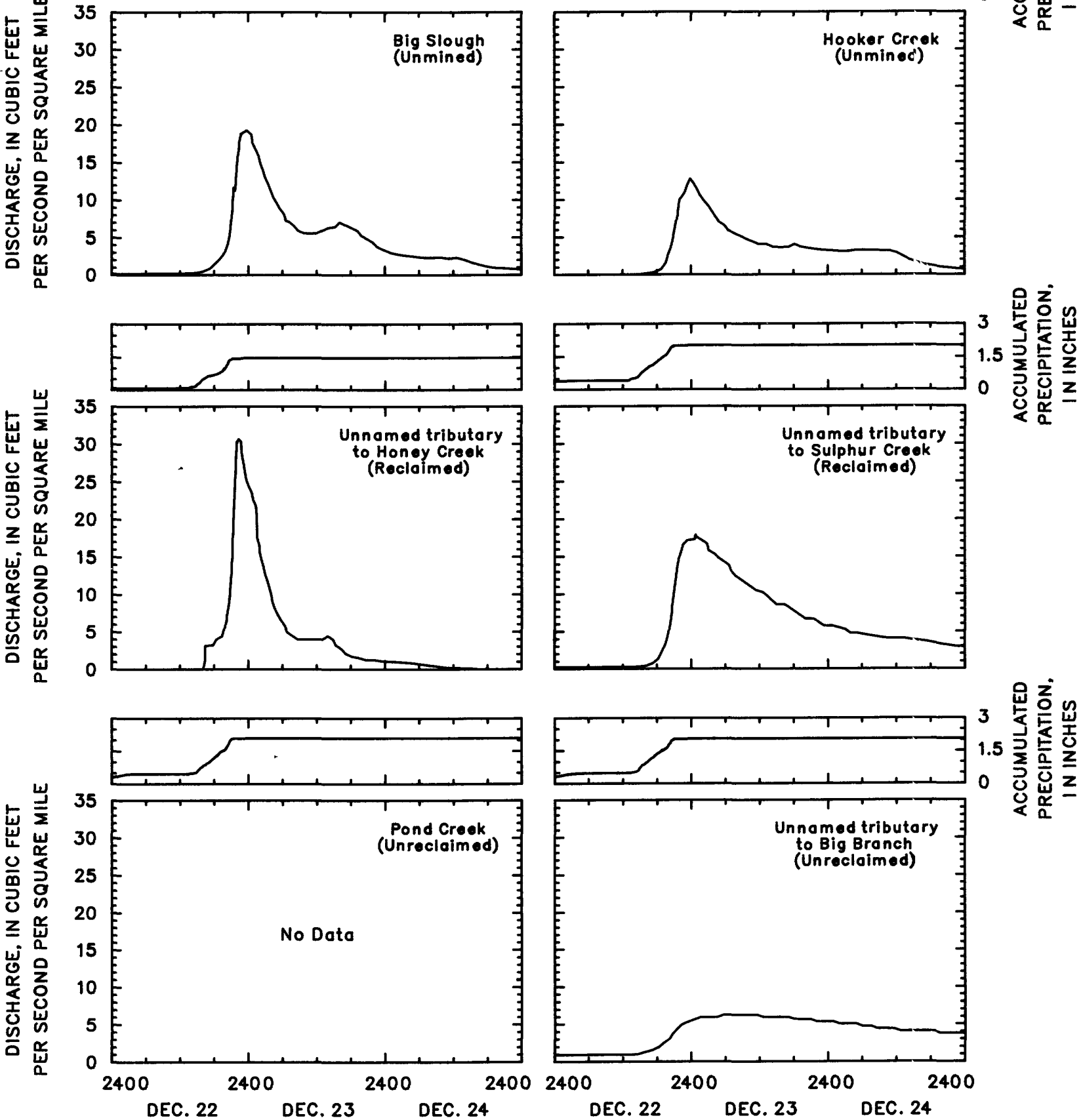

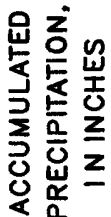

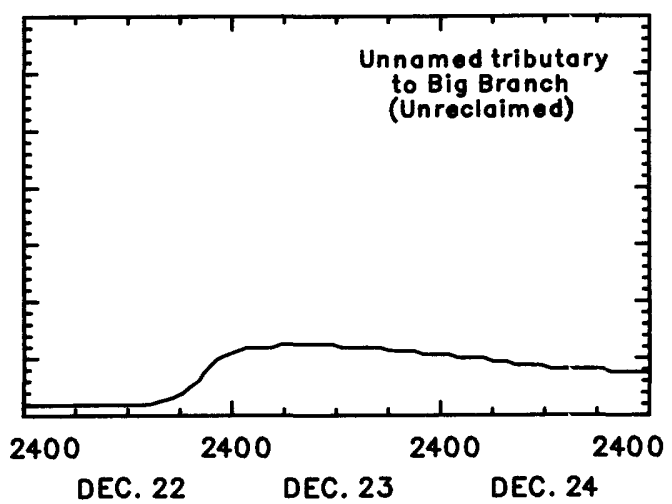

Figure $9 F$. Instantaneous discharge and accumulated precipitation for six study watersheds for frontal storm of December 21-22, 1981. 
Table $5 F$. Volumes of precipitation and runoff and times from beginning of rise to peak discharge at six study watersheds for the frontal storm of December 21-22, 1981

$[-$, no data available; in., inch $]$

\begin{tabular}{|c|c|c|c|c|c|c|c|c|c|}
\hline \multirow[b]{2}{*}{ Watershed } & \multirow[b]{2}{*}{$\begin{array}{l}\text { Precipitation } \\
\text { volume (in.) }\end{array}$} & \multirow[b]{2}{*}{$\begin{array}{l}\text { Storm runoff } \\
\text { volume }^{1} \text { (in.) }\end{array}$} & \multirow[b]{2}{*}{$\begin{array}{l}\text { Runoff } \\
\text { coefficient }{ }^{2} \\
\text { (percent) }\end{array}$} & \multirow{2}{*}{$\begin{array}{l}\text { Time from } \\
\text { rise to peak } \\
\text { (hours) }\end{array}$} & \multicolumn{3}{|c|}{ Maximum precipitation intensity for } & \multicolumn{2}{|c|}{ Precipitation during previous } \\
\hline & & & & & 5 minutes & $\begin{array}{l}10 \text { minutes } \\
\text { (in.) }\end{array}$ & $\begin{array}{l}1 \text { hour } \\
\text { (in.) }\end{array}$ & $\begin{array}{l}3 \text { days } \\
\text { (in.) }\end{array}$ & $\begin{array}{l}7 \text { days } \\
\text { (in.) }\end{array}$ \\
\hline $\begin{array}{l}\text { Big Slough } \\
\text { (Unmined) }\end{array}$ & 1.83 & 0.43 & 23.5 & 15.83 & 0.05 & 0.09 & 0.40 & 0.00 & 0.00 \\
\hline $\begin{array}{l}\text { Hooker Creek } \\
\text { (Unmined) } \ldots \ldots \ldots \ldots\end{array}$ & 1.93 & .35 & 18.1 & 15.92 & .11 & .14 & .61 & .00 & .00 \\
\hline $\begin{array}{l}\text { Unnamed tributary to Honey } \\
\text { Creek (Reclaimed) ....... }\end{array}$ & 1.47 & .38 & 25.9 & 5.75 & .07 & .12 & .41 & .00 & .00 \\
\hline $\begin{array}{l}\text { Unnamed tributary to Sulphur } \\
\text { Creek (Reclaimed) } \ldots \ldots \text {. }\end{array}$ & 2.03 & .76 & 37.4 & 10.50 & .07 & .09 & .37 & .00 & .00 \\
\hline $\begin{array}{l}\text { Pond Creek } \\
\text { (Unreclaimed) } \ldots \ldots \ldots \ldots \\
\text { Unnamed tributary to Big }\end{array}$ & 2.09 & - & - & - & .08 & .13 & .44 & .00 & .00 \\
\hline Branch (Unreclaimed) ... & 2.05 & .57 & 27.8 & 25.00 & .06 & .09 & .36 & .00 & .00 \\
\hline
\end{tabular}

${ }^{1}$ Storm runoff volume is the total runoff volume minus the base-flow volume.

${ }^{2}$ Runoff coefficient is storm runoff volume divided by precipitation volume multiplied by 100 percent. 

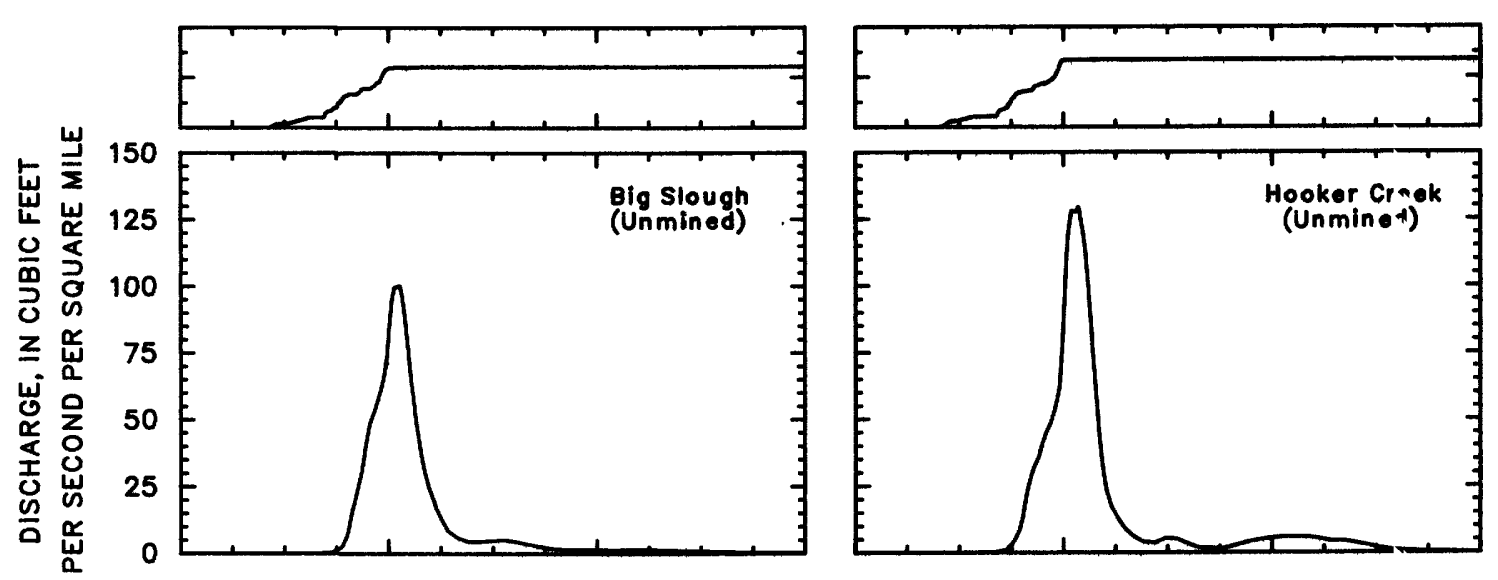

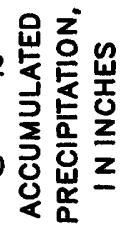
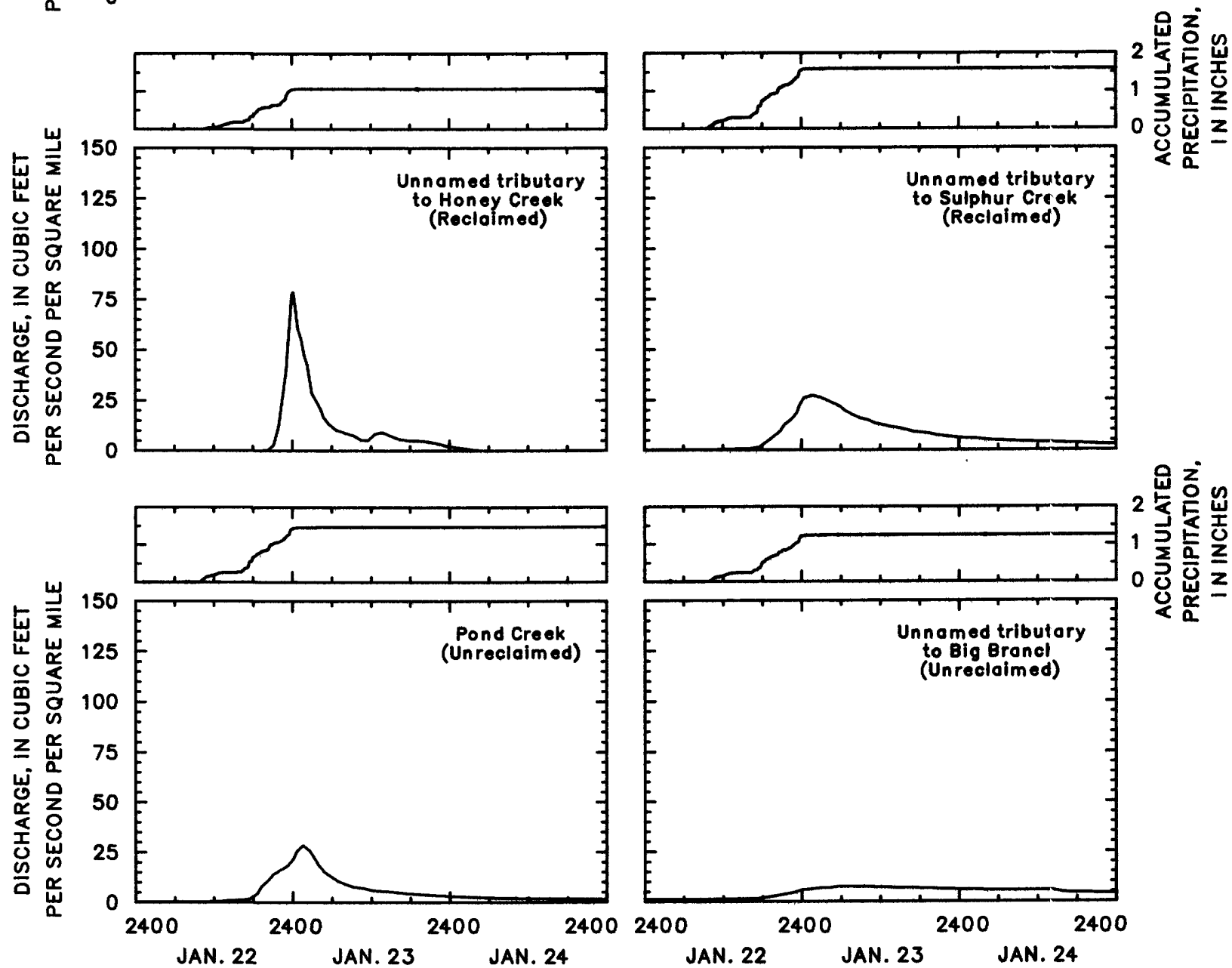

Figure 9G. Instantaneous discharge and accumulated precipitation for six study watersheds for frontal storm of January 22, 1982. 
Table 5G. Volumes of precipitation and runoff and times from beginning of rise to peak discharge at six study wate"sheds for the frontal storm of January 22, 1982

[in., inch]

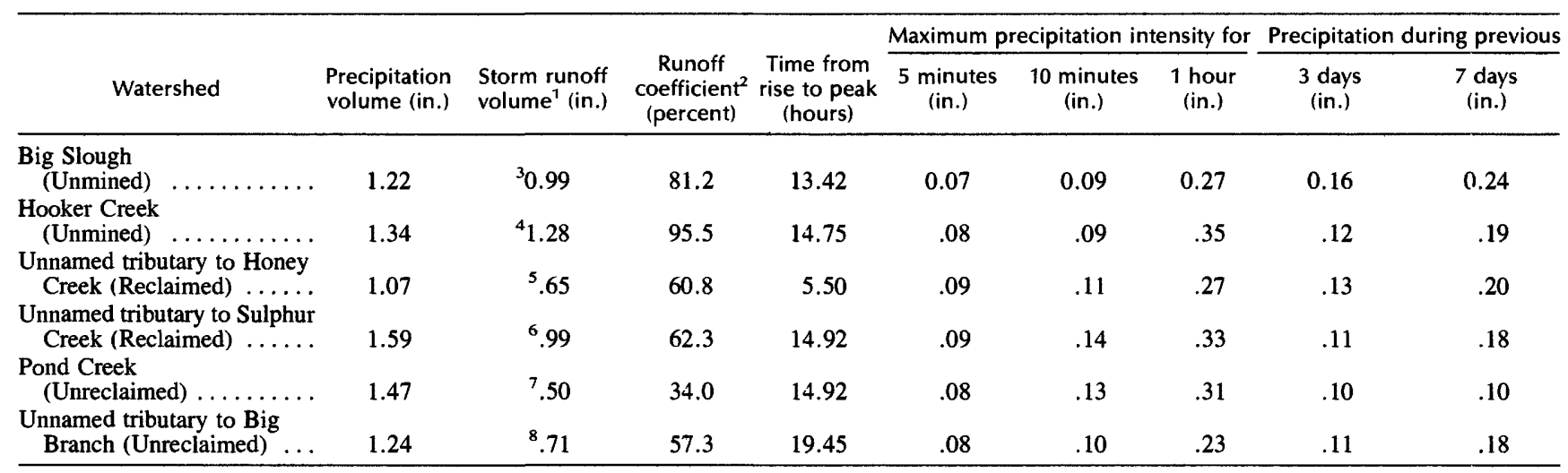

${ }^{1}$ Storm runoff volume is the total runoff volume minus the base-flow volume.

${ }^{2}$ Runoff coefficient is storm runoff volume divided by precipitation volume multiplied by 100 percent.

${ }^{3}$ Storm runoff may include up to $0.26 \mathrm{in}$. from snowmelt.

${ }^{4} \mathrm{Storm}$ runoff may include up to $0.20 \mathrm{in}$. from snowmelt.

${ }^{5}$ Storm runoff may include up to $0.24 \mathrm{in}$. from snowmelt.

${ }^{6} \mathrm{Storm}$ runoff may include up to 0.23 in. from snowmelt.

${ }^{7}$ Storm runoff may include up to $0.10 \mathrm{in}$. from snowmelt.

${ }^{8} \mathrm{Storm}$ runoff may include up to $0.31 \mathrm{in}$. from snowmelt. 

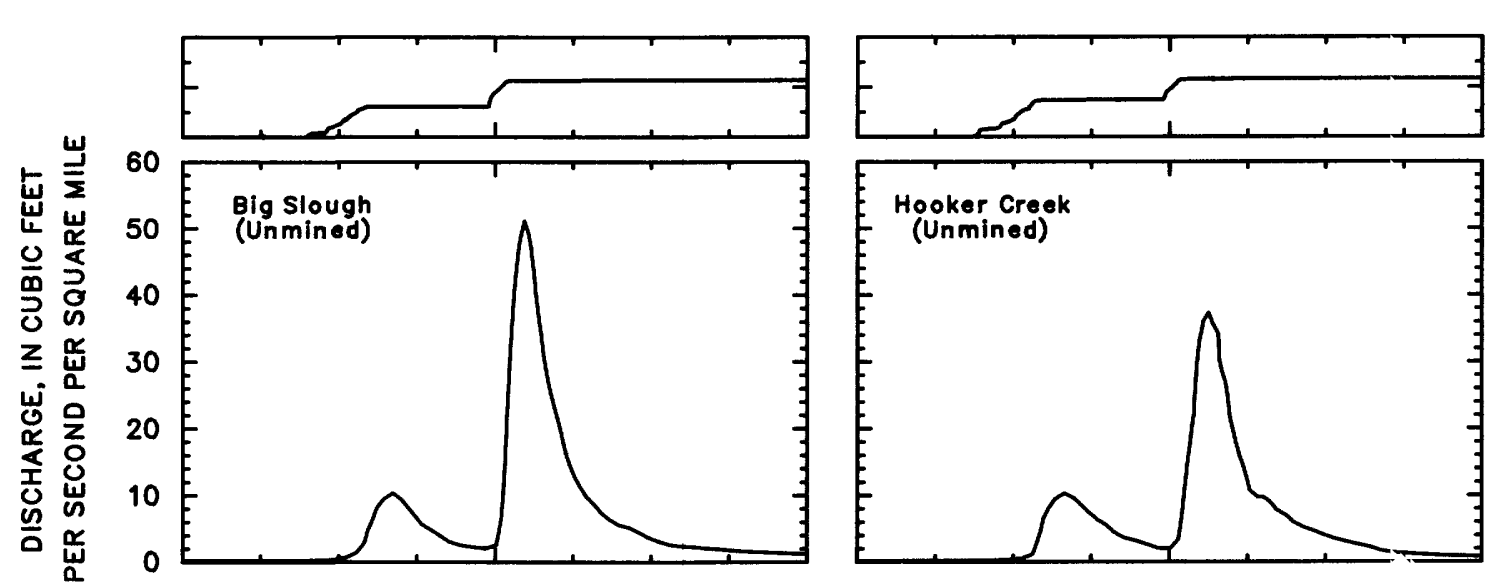

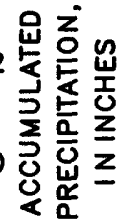
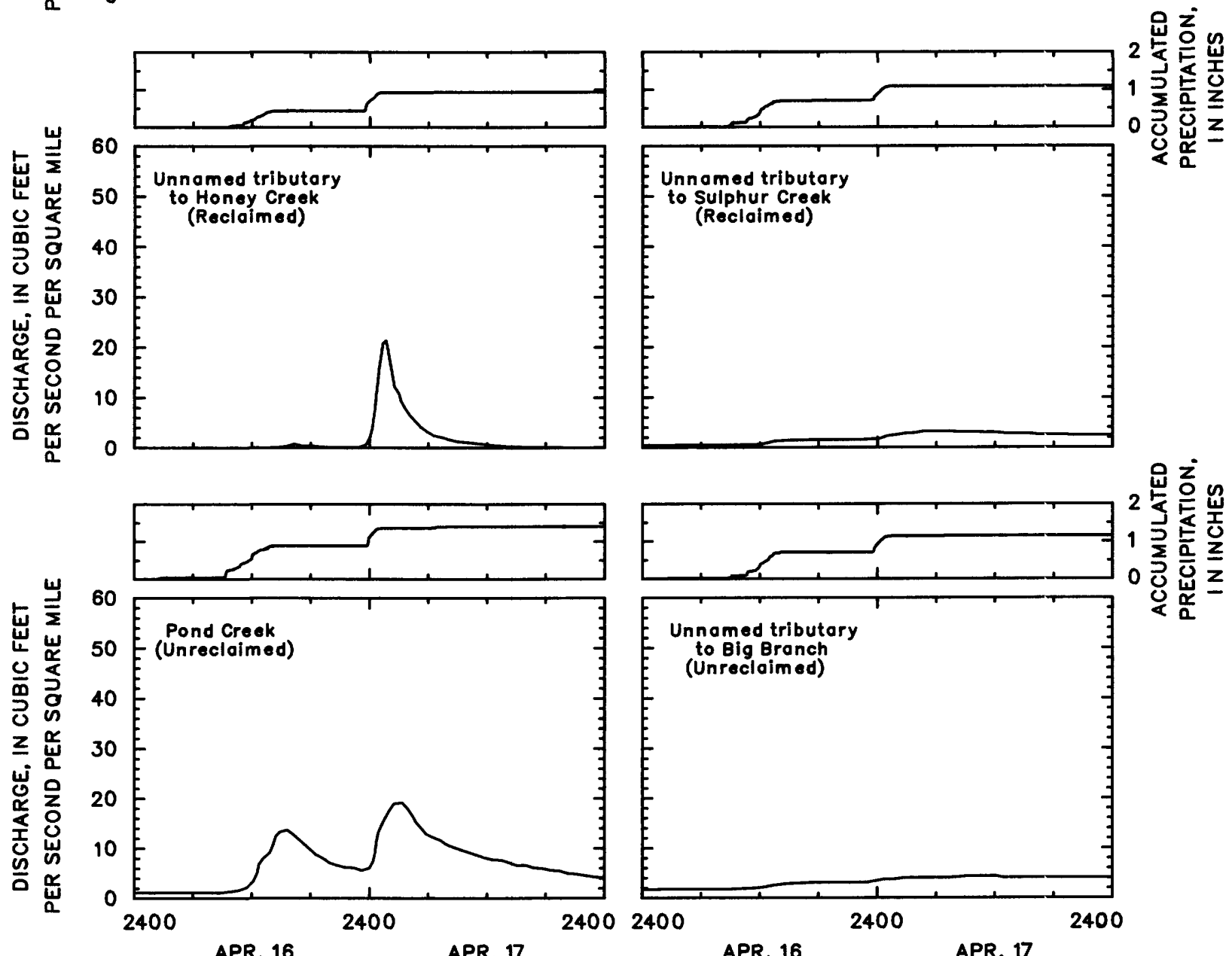

Figure $9 \mathrm{H}$. Instantaneous discharge and accumulated precipitation for six study watersheds for frontal storm of April 16-17, 1982. 
Table $5 \mathrm{H}$. Volumes of precipitation and runoff and times from beginning of rise to peak discharge at six study watersheds for the frontal storm of April 16-17, 1982

[in., inch]

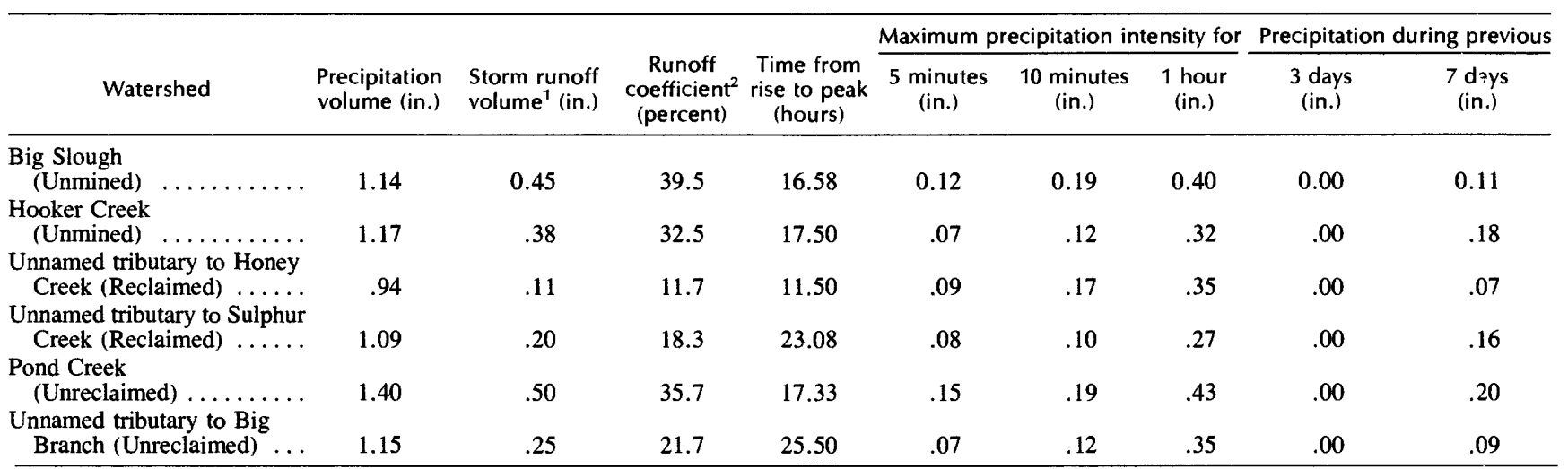

${ }^{1}$ Storm runoff volume is the total runoff volume minus the base-flow volume.

${ }^{2}$ Runoff coefficient is storm runoff volume divided by precipitation volume multiplied by 100 percent. 


\section{SELECTED SERIES OF U.S. GEOLOGICAL SURVEY PUBLICATIONS}

\section{Periodicals}

Earthquakes \& Volcanoes (issued bimonthly).

Preliminary Determination of Epicenters (issued monthly).

\section{Technical Books and Reports}

Professional Papers are mainly comprehensive scientific reports of wide and lasting interest and importance to professional scientists and engineers. Included are reports on the results of resource studies and of topographic, hydrologic, and geologic investigations. They also include collections of related papers addressing different aspects of a single scientific topic.

Bulletins contain significant data and interpretations that are of lasting scientific interest but are generally more limited in scope or geographic coverage than Professional Papers. They include the results of resource studies and of geologic and topographic investigations, as well as collections of short papers related to a specific topic.

Water-Supply Papers are comprehensive reports that present significant interpretive results of hydrologic investigations of wide interest to professional geologists, hydrologists, and engineers. The series covers investigations in all phases of hydrology, including hydrogeology, availability of water, quality of water, and use of water.

Circulars present administrative information or important scientific information of wide popular interest in a format designed for distribution at no cost to the public. Information is usually of short-term interest.

Water-Resources Investigations Reports are papers of an interpretive nature made available to the public outside the formal USGS publications series. Copies are reproduced on request unlike formal USGS publications, and they are also available for public inspection at depositories indicated in USGS catalogs.

Open-File Reports include unpublished manuscript reports, maps, and other material that are made available for public consultation at depositories. They are a nonpermanent form of publication that may be cited in other publications as sources of information.

\section{Maps}

Geologic Quadrangle Maps are multicolor geologic maps on topographic bases in 7.5- or 15-minute quadrangle formats (scales mainly $1: 24,000$ or $1: 62,500$ ) showing bedrock, surficial, or engineering geology. Maps generally include brief texts; some maps include structure and columnar sections only.

Geophysical Investigations Maps are on topographic or planimetric bases at various scales; they show results of surveys using geophysical techniques, such as gravity, magnetic, seismic, or radioactivity, which reflect subsurface structures that are of economic or geologic significance. Many maps include correlations with the geology.

Miscellaneous Investigations Series Maps are on planimetric or topographic bases of regular and irregular areas at various scales; they present a wide variety of format and subject matter. The series also includes 7.5-minute quadrangle photogeologic maps on planimetric bases that show geology as interpreted from aerial photographs. Series also includes maps of Mars and the Moon.
Coal Investigations Maps are geologic maps on topographic or planimetric bases at various scales showing bedrock or surficial geology, stratigraphy, and structural relations in certain coal-resource areas.

Oil and Gas Investigations Charts show stratigraphic information for certain oil and gas fields and other areas having petroleum potential.

Miscellaneous Field Studies Maps are multicolor or blackand-white maps on topographic or planimetric bases on quadrangle or irregular areas at various scales. Pre-1971 maps show bedrock geology in relation to specific mining or mineral-deposit problems; post-1971 maps are primarily black-and-white maps on various subjects such as environmental studies or wilderness mineral investigations.

Hydrologic Investigations Atlases are multicolored or blackand-white maps on topographic or planimetric bases presenting a wide range of geohydrologic data of both regular and irregular areas; principal scale is $1: 24,000$, and regional studies are at 1:250,000 scale or smaller.

\section{Catalogs}

Permanent catalogs, as well as some others, giving comprehensive listings of U.S. Geological Survey publications are available under the conditions indicated below from the U.S. Geological Survey, Books and Open-File Reports Section, Federal Center, Box 25425. Denver. CO 80225. (See latest Price and Availability List.)

"Publications of the Geological Survey, 1879-1961" may be purchased by mail and over the counter in paperback book form and as a set of microfiche.

"Publications of the Geological Survey, 1962-1970" may be purchased by mail and over the counter in paperback book form and as a set of microfiche.

"Publications of the U.S. Geological Survey, 1971-1981" may be purchased by mail and over the counter in paperback book form (two volumes, publications listing and index) and as a set of microfiche.

Supplements for 1982,1983, 1984, 1985, 1986, and for subsequent years since the last permanent catalog may be purchased by mail and over the counter in paperback book form.

State catalogs, "List of U.S. Geological Survey Geologic and Water-Supply Reports and Maps For (State)," may be purchased by mail and over the counter in paperback booklet form only.

"Price and Availability List of U.S. Geological Survey Publications," issued annually, is available free of charge in paperback booklet form only.

Selected copies of a monthly catalog "New Publications of the U.S. Geological Survey" are available free of charge by mail or may be obtained over the counter in paperback booklet form only. Those wishing a free subscription to the monthly catalog "New Publications of the U.S. Geological Survey" should write to the U.S. Geological Survey, 582 National Center, Reston, VA 22092.

Note.-Prices of Government publications listed in older catalogs, announcements, and publications may be incorrect. Therefore, the prices charged may differ from the prices in catalogs, announcements, and publications. 
